\title{
23. LOCAL VERSUS REGIONAL MANTLE HETEROGENEITIES: EVIDENCE FROM HYGROMAGMAPHILE ELEMENTS ${ }^{1}$
}

\author{
H. Bougault, Institut Français pour la Recherche et l'Exploitation de la Mer, Centre de Brest \\ J. L. Joron, Centre National de la Recherche Scientifique, Laboratoire Pierre Sue \\ M. Treuil, Laboratoire Géochimie, Université Pierre et Marie Curie \\ and \\ R. Maury, Université de Bretagne Occidentale ${ }^{2}$
}

\begin{abstract}
The main objective of Leg 82 of the Glomar Challenger was to document mantle heterogeneity in the vicinity of, and away from, a so-called hot spot: the Azores Triple Junction. One of the geochemical tools that permits, at least in part, the recognition of mantle heterogeneities uses hygromagmaphile elements, those elements that have an affinity for the liquid. This tool is presented in terms of an extended Coryell-Masuda plot, which incorporates within the rare earth elements the hygromagmaphile transition elements Th, Ta, Zr, Hf, Ti, Y, and V. The extended Coryell-Masuda plot is used to summarize our knowledge of mantle heterogeneity along the ridge axis at zero-age. It is also used by choosing those hygromagmaphile elements that can be analyzed on board by X-ray fluorescence spectrometry to give preliminary information on the enriched or depleted character of recovered samples. Shore-based results, which include analyses of most of the hygromagmaphile elements measured either by X-ray spectrometry or neutron activation analysis, confirm the shipboard data.

From the point of view of comparative geochemistry, the variety of basalts recovered during Leg 82 provides a good opportunity to test and verify the classification of the hygromagmaphile elements. Analyses from Leg 82 provide new data about the relationship between extended rare earth patterns (enriched or depleted) that can be estimated either by $\mathrm{La} / \mathrm{Sm}$ ratio or $\mathrm{Nb} / \mathrm{Zr}$ (or Ta/Hf) ratios: samples from Hole 556 are depleted (low $\mathrm{Nb} / \mathrm{Zr}$ ratio) but have a high ${ }^{206} \mathrm{~Pb}$ / ${ }^{204} \mathrm{~Pb}(19.5)$ ratio; in Hole 558 a moderately enriched basalt unit with a $\mathrm{La} / \mathrm{Sm}(=\mathrm{Nb} / \mathrm{Zr}$ ) ratio (chondrite normalized) of 2 has a high ${ }^{206} \mathrm{~Pb} /{ }^{204} \mathrm{~Pb}(20)$ ratio. One of the most interesting results of Leg 82 lies in the crossing patterns of extended Coryell-Masuda plots for basalts from the same hole. This result enhances the notion of local mantle heterogeneity versus regional mantle heterogeneity and is confirmed by isotope data; it also favors a model of short-lived, discrete magma chambers. The data tend to confirm the Hayes Fracture Zone as a southern limit for the influence of Azores-type mantle. Nevertheless, north of the Hayes Fracture Zone, the influence of a plumelike mantle source is not simple and probably requires an explanation more complex than a contribution from a single fixed hot spot.
\end{abstract}

\section{INTRODUCTION}

The basalts of the ocean floor formed at spreading centers (mid-ocean ridge basalts: MORB) were considered to have a tholeiitic composition very similar in all of the oceans. This composition is markedly different from the composition of basalts from ocean islands (Engel et al., 1965). The most important differences between the two types are represented by radiogenic $\mathrm{Sr}, \mathrm{Pb}$, and Nd ratios (Gast et al., 1964; Tatsumoto et al., 1965; Hart et al., 1973; Sun, 1973; Richard et al., 1976; O'Nions et al., 1977), and their relative light to heavy rare earth element (REE) fractionation (Frey and Haskin, 1964; Gast, 1968; Sun et al., 1979). Ocean island basalts (both alkali and tholeiitic) are characterized by higher ${ }^{87} \mathrm{Sr} /{ }^{86} \mathrm{Sr}$, ${ }^{206} \mathrm{~Pb} /{ }^{204} \mathrm{~Pb},{ }^{207} \mathrm{~Pb} /{ }^{204} \mathrm{~Pb},{ }^{208} \mathrm{~Pb} /{ }^{204} \mathrm{~Pb}$, lower ${ }^{143} \mathrm{Nd} /{ }^{144} \mathrm{Nd}$, and higher $\mathrm{La} / \mathrm{Sm}$ ratios than MORB. Typical mid-ocean

\footnotetext{
${ }^{1}$ Bougault, H., Cande, S. C., et al., Init, Repts. DSDP, 82: Washington (U.S. Govt. Printing Office).

2 Addresses: (Bougault) Institut de Français pour la Recherche et l'Exploitation de la Mer (formerly Centre National pour l'Exploitation des Océans), Centre de Brest, B. P. 337. 29273 Brest Cedex, France; (Joron) Centre National de la Recherche Scientifique, Laboratoire Pierre Sue, Centre d'Etude Nucléaire Saclay, B. P. No. 2, 91191 Gif-Sur-Yvette, France; (Treuil) Laboratoire Géochimie, Université Pierre et Marie Curie, 4 place Jussieu, 75230 Paris Cedex 05, France; (Maury) Université de Bretagne Occidentale, 6 avenue Le Gorgeu, 29283 Brest Cedex, France.
}

ridge basalts are also called depleted MORB because they are depleted in the most hygromagmaphile elements (i.e., those elements that have low bulk crystal-liquid partition coefficients).

Theoretically, different ratios of hygromagmaphile elements such as $\mathrm{La} / \mathrm{Sm}$ can be explained as characteristic of different mantle sources and by fractionation during magmatic processes, mainly partial melting (Langmuir et al., 1977; Bougault, Cambon, et al., 1979). Theoretically, different isotopic ratios of $\mathrm{Sr}, \mathrm{Pb}$, and $\mathrm{Nd}$ can only be interpreted in terms of different mantle sources. One type of mantle source is associated with the notion of a mantle plume or hot spot (Wilson, 1963; Morgan, 1971; Schilling, 1973) and is related to intraplate volcanism (e.g., Hawaiian Seamount Chain). Another type of mantle source is associated with the generation of MORBs and the notion of a low velocity layer in the oceanic mantle (Schilling, 1971). However, limiting the number of types of oceanic basalts to two is an oversimplification. The acronym MORB was corrected by using typical MORB or depleted MORB. The usage of the expression "normal ridge segment" started at the same time. Some parts of ridges at zero-age have geochemical characteristics (isotopic ratios, rare earth concentrations) that tend to resemble intraplate volcanism; these locations are cha- 
racterized by "anomalous topographic highs." Three areas of this type have been intensively studied in the North Atlantic: Iceland, $45^{\circ} \mathrm{N}$, and the Azores Triple Junction. However, there are not simply "normal" segments and "abnormal" ridge segments at zero-age, but a gradation along the ridge axis even if it is not a smooth continuous variation (Schilling, 1973; Hart et al., 1973; Sun et al., 1975; Schilling, 1975; White and Schilling, 1978; Tarney et al., 1980; Bougault and Treuil, 1980). This feature has been interpreted as a mixing of two mantle sources. One of them has its origin in the deep mantle and forms a mantle plume or blob that is responsible for the formation of thicker ocean crust with a morphology different from that of normal ridge segments; this mantle plume has more primordial characteristics than the normal ridge. The source that feeds normal ridge segments at the accreting plate boundaries has been depleted in hygromagmaphile elements a long time ago; this depletion, as a consequence of the fractionation of $\mathrm{Rb}-\mathrm{Sr}, \mathrm{U}$ and $\mathrm{Th}-\mathrm{Pb}, \mathrm{Sm}-\mathrm{Nd}$, leads to radiogenic isotope ratios $(\mathrm{Sr}, \mathrm{Pb}, \mathrm{Nd})$ that are different from those of mantle plume material.

The variation of concentrations of light and heavy REEs (La/Sm ratio) and isotopic ratios (e.g., Sr) along the axis of the Mid-Atlantic Ridge, specifically from the Azores hot spot to the Atlantis Fracture Zone, have been well documented by Schilling (1975) and White and others (1976). Even if the variations observed along the axis are not smoothly continuous, a gradation does exist from enriched basalts at the Azores Triple Junction to depleted basalts south of $33^{\circ} \mathrm{N}$. These variations were confirmed in 1979 by the MAPCO cruise (Bougault and Treuil, 1980). For zero-age basalts, the limit of the influence of the Azores mantle plume was found to be at the latitude of the Hayes Fracture Zone. But, as already pointed out by Schilling (1975), these results do not give any information about the time of the first appearance of a blob beneath the Azores. In other words, to get information about the contribution of the mantle plume versus time, we needed to drill away from the axis of the ridge. We realized that we might have to consider several possible variations versus time (such as the presence and the influence of other hot spots at a given time or discontinuous functioning of mantle blobs). First, however, we asked whether or not there were gradations versus time (away from the axis of the ridge) and along isochrons (away from a supposed fixed hot spot), and whether or not these gradations were similar to what is observed today for zero-age basalts.

In this paper, we present information about the geochemical tool represented by hygromagmaphile elements to trace mantle heterogeneities. Hygromagmaphile elements other than REEs that can be integrated in an extended Coryell-Masuda plot permitted us to obtain useful information on board for conducting the cruise. In order to complete the data set and facilitate comparisons, we include data for zero-age samples. Leg 82 data are presented in terms of comparative geochemistry and petrology; finally, we discuss the main discoveries and conclusions of Leg 82 of the Glomar Challenger.

\section{EXTENDED CORYELL-MASUDA PLOT AND CLASSIFICATION OF HYGROMAGMAPHILE ELEMENTS}

The term "hygromagmaphile" was initially proposed by Treuil (1973) to introduce the notion of affinity of some elements for the liquid phase of a magma. Treuil (1973) proposed that the behavior of such elements-often referred to as large ion lithophile elements (LIL) - be considered the result of both their difficulty entering a crystal structure and their ability to form complexes in the liquid phase of the magma.

Many of these elements, especially the REEs, have been the subject of several investigations: elements of the first transition series $(\mathrm{Sc}, \mathrm{Ti}, \mathrm{V})$; the second transition series $(\mathrm{Y}, \mathrm{Zr}, \mathrm{Nb}$ ); the third transition series (Lanthanides, Hf, $\mathrm{Ta}$ ); and also heavy elements like Th and $\mathrm{U}$. The elements of the two first columns of the classification of the elements have also been the matter of discussion and interpretation in terms of LIL elements. Nevertheless, very few studies (if any) were concerned with the study of all of these elements on the same samples. The "Groupe des Sciences de la Terre du Laboratoire P. Sue du Centre National de la Recherche Scientifique" for neutron activation analysis (NAA), and the "Groupe de Géochimie du Centre Océanologique de Bretagne" for X-ray fluorescence analysis (XRF) have, since 1973-1974, obtained a large set of data on the same basalt samples. Before using certain elements or groups of elements to deduce information about magmatic processes or mantle heterogeneity, we will use this data set to establish a classification of these elements with respect to their affinity for the liquid phase. In a first step, we will use the continuous variation of the properties of rare earth elements; considering the well-known Coryell-Masuda plot (Masuda, 1962; Coryell et al., 1963), we will see to what extent hygromagmaphile elements can be plotted in such a diagram, and to what extent it is possible to establish a classification of hygromagmaphile elements versus their affinity for the liquid. In a second step, this classification, which has been obtained through comparative geochemistry, will be compared to a classification deduced from a more theoretical approach, involving both crystal structural and complexing considerations.

The hygromagmaphile character of the elements $\mathrm{Ti}$, $\mathrm{V}, \mathrm{Y}, \mathrm{Zr}, \mathrm{Nb}$, Lanthanides, Hf, Ta, and Th is well established. Yttrium, whose physicochemical properties are very close to the properties of heavy REEs, has already been included in a Coryell-Masuda plot (Frey et al., 1968). A triangular diagram has been proposed by Pearce and Cann (1971) for $\mathrm{Zr}, \mathrm{Ti}$, and $\mathrm{Y}$. The relative behavior of $\mathrm{Zr}$ and $\mathrm{Nb}$ was studied by Erlank and Kable (1976). A correlation between $\mathrm{Ti}$ and Dy was shown by Bougault (1977) for ocean basalts and ophiolite suites. Hf, Ta, and Th were studied by Treuil (1973) and Treuil and others (1979). The absence of fractionation between elements of the second and third transition series that belong to the same column of the classification of the elements (namely the pairs Y-heavy REEs, Zr-Hf, and $\mathrm{Nb}-\mathrm{Ta}$ ) was shown by Bougault, Joron, and others (1979). 
All these transition elements have a common property: they tend to have ions whose external electronic structure corresponds to the external electronic structure of rare gases. Also, all these elements are nonvolatile in respect to accretion processes and they are all lithophile. All these properties are common to the REEs, and it should be possible to normalize their concentrations in basalts to chondrite concentrations and to incorporate them in an extended Coryell-Masuda plot.

The observed abundances of REEs and other hygromagmaphile elements in chondrites vary by more than a factor of 20. The normalization values used for REEs are generally average concentrations obtained from different chondrites (Frey et al., 1968). Other authors prefer normalization values obtained from the concentrations of a reference chondrite, but accounting for the ratio "bulk rare earth content of the composite chondrite/ bulk rare earth content of the reference chondrite" (Sun and Hanson, 1975). None of these methods can be used at the present time for $\mathrm{Th}, \mathrm{Ta}, \mathrm{Nb}, \mathrm{Hf}, \mathrm{Zr}, \mathrm{Ti}$, and $\mathrm{V}$. The average concentrations of these elements from the same chondrites as for REEs are not available; in addition, a large dispersion of values exists between different authors for the same element in the same chondrite. Because of the difficulties in obtaining normalization values from chondrites, we propose to compute normalization values as follows.

We make the hypothesis that non-rare-earth hygromagmaphile elements behave similarly to the REEs. First, we choose a basalt sample A whose Coryell-Masuda plot is flat (i.e., a sample whose normalized concentrations of REEs all have the same value of $R_{\mathrm{A}}$ ). If this hypothesis is valid, other hygromagmaphile elements will have the same normalized concentrations $R_{\mathrm{A}}$. For an element $\mathrm{i}$, it is possible to compute its normalization value $C h_{\mathrm{i}}$ from $R_{\mathrm{A}}$ and the concentration of element $i$ in Sample $\mathrm{A}, C_{\mathrm{Ai}}$ :

$$
C h_{\mathrm{i}}=\frac{C_{\mathrm{Ai}}}{R_{\mathrm{A}}}
$$

Second, we verify that these normalization values $C h_{\mathrm{i}}$ produce constant normalized concentrations $R_{\mathrm{B}}, R_{\mathrm{C}}, \ldots$ for all hygromagmaphile elements of samples $\mathrm{B}, \mathrm{C}, \ldots$, whose rare earth Coryell-Masuda plots are also flat, but have different $R_{\mathrm{B}}, R_{\mathrm{C}} \ldots$ To be significant, this verification requires that samples $\mathrm{B}, \mathrm{C}, \ldots$ are chosen from different locations of the Earth. It is somewhat difficult to find samples whose rare earth patterns are absolutely flat. Figures 1 and 2 show some examples obtained during Leg 37 (Mid-Atlantic Ridge, $36^{\circ} \mathrm{N}$ ) and Leg 49 (Reykjanes Ridge). The normalization values that have been found and used to construct Figures 1 and 2 are shown in the following list. Except for V, all values lie in the range of published concentrations for chondrites and often seem to represent correct averages.

This list contains the normalization values of hygromagmaphile elements. Underlined elements correspond to elements whose normalization values have been calculated by the proposed method.

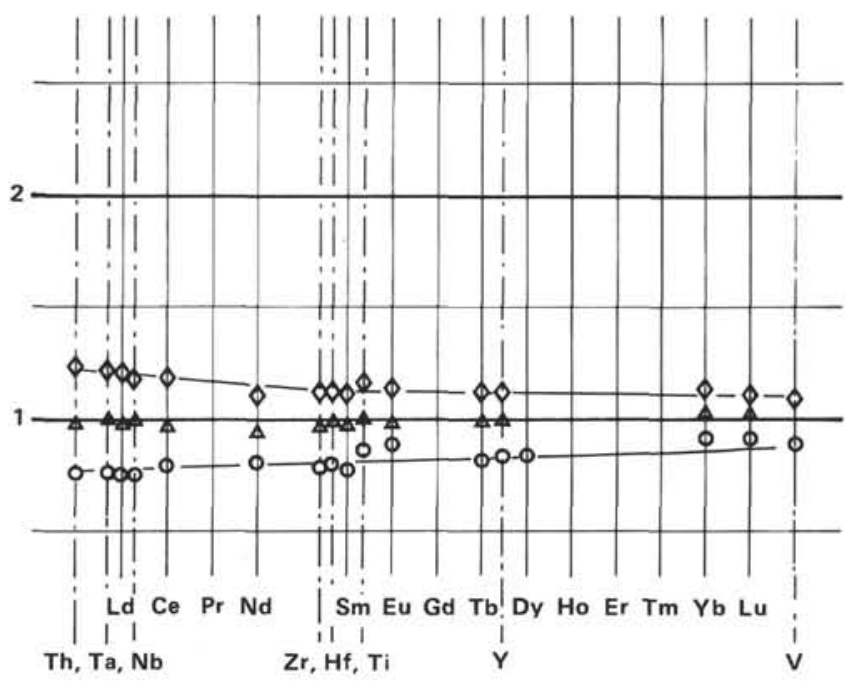

Figure 1. Flat or almost flat "extended" Coryell-Masuda plots: samples from Hole $332 \mathrm{~B}\left(36^{\circ} \mathrm{N}\right): \diamond 332 \mathrm{~B}-3-4 ; \triangle 332 \mathrm{~B}-25-3$; $\bigcirc 332 \mathrm{~B}-$ $36-3$ and 332B-37-1. For data, see Bougault, 1980. On the $y$ axis is the logarithm of the normalized concentrations.

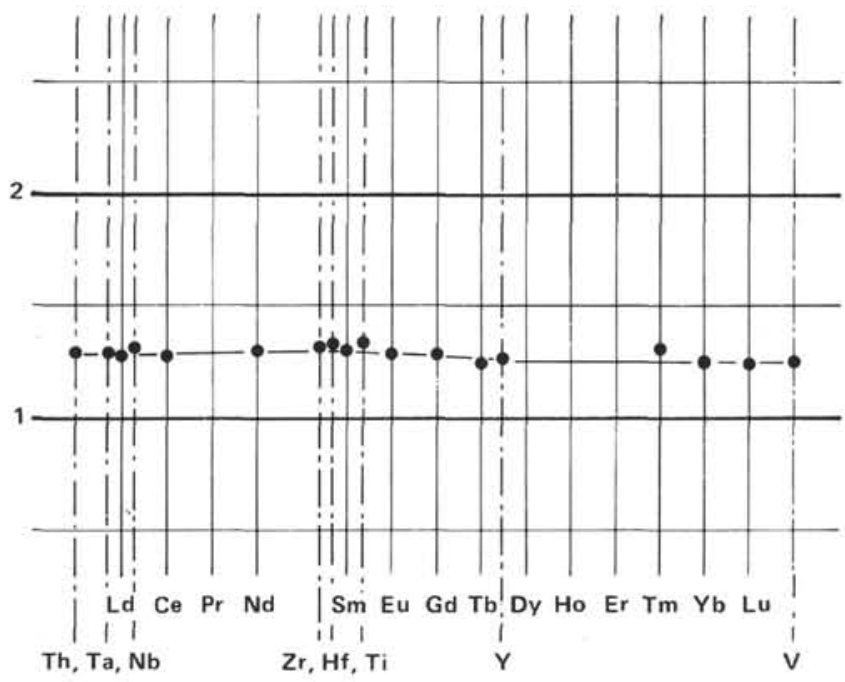

Figure 2. Flat "extended" Coryell-Masuda plot: samples from Hole 409 (Reykjanes Ridge, $63^{\circ} \mathrm{N}$ ), 409-13-3 to 409-31-1. For data, see Bougault, 1980 and Woods, Varet, et al., 1979. On the $y$ axis is the logarithm of the normalized concentrations.

\begin{tabular}{llll}
\hline $\mathrm{Th}$ & 0.028 & $\mathrm{Eu}$ & 0.07 \\
$\mathrm{La}$ & 0.32 & $\mathrm{Gd}$ & 0.25 \\
$\underline{\mathrm{Ta}}$ & 0.031 & $\mathrm{~Tb}$ & 0.047 \\
$\underline{\mathrm{Nb}}$ & 0.53 & $\underline{\mathrm{Y}}$ & 2.16 \\
$\mathrm{Ce}$ & 0.85 & $\mathrm{Dy}$ & 0.32 \\
$\mathrm{Pr}$ & 0.112 & $\mathrm{Ho}$ & 0.07 \\
$\mathrm{Nd}$ & 0.60 & $\mathrm{Er}$ & 0.21 \\
$\underline{\mathrm{Zr}}$ & 5.13 & $\mathrm{Tm}$ & 0.03 \\
$\underline{\mathrm{Hf}}$ & 0.128 & $\mathrm{Yb}$ & 0.20 \\
$\mathrm{Sm}$ & 0.19 & $\mathrm{Lu}$ & 0.033 \\
$\underline{\mathrm{Ti}}$ & 460 & $\underline{\mathrm{V}}$ & 22 \\
\hline
\end{tabular}

If the non-rare-earth hygromagmaphile elements plot in an extended Coryell-Masuda diagram, it is necessary 
to find the location of these elements within the rare earth atomic numbers ( $x$ axis). The normalized concentrations of non-rare-earth elements must then plot on the REE normalized pattern. In other words, the Coryell-Masuda plot extended to non-rare-earth elements allows us to obtain a classification of hygromagmaphile elements. Because of the continuous variation of their properties (versus atomic number), the REEs are used as a calibration scale for the hygromagmaphile character of the elements. This classification is obtained in two steps. We choose a sample whose REE pattern is very different from flat (enriched, for instance). The position of the elements within the REEs on the $\mathrm{x}$ axis is determined from their normalized concentrations (using normalization values obtained above) in the sample (Fig. 3). In a second step, with these positions of the elements and normalization values, we verify that continuous extended REE patterns are obtained for samples having different shapes of REE patterns. Typical examples are given in Figure 4. The discrepancy observed for $\mathrm{Nb}$ and $\mathrm{Ta}$ in the depleted samples will be discussed later. The classification of hygromagmaphile elements can be read on these diagrams ( $\mathrm{x}$ axis) from Th to V (representing decreasing affinity for the liquid).

The basic property of hygromagmaphile elementstheir affinity for the liquid phase of a magma-is the consequence of two effects: difficulty entering crystal structures (because of large ionic size), and complexing in the liquid (for ions that have high charge and small ionic radii) (Ringwood, 1955; Treuil, 1973). For a first approximation, the difficulty in entering a crystal structure can be estimated to be proportional to the difference between the ionic radius of the hygromagmaphile element and the radius of the major element that it is supposed to replace it in the crystal. The facility to form a complex in the liquid can be estimated to be proportional to the ionic potential of the element (charge/ionic radius).

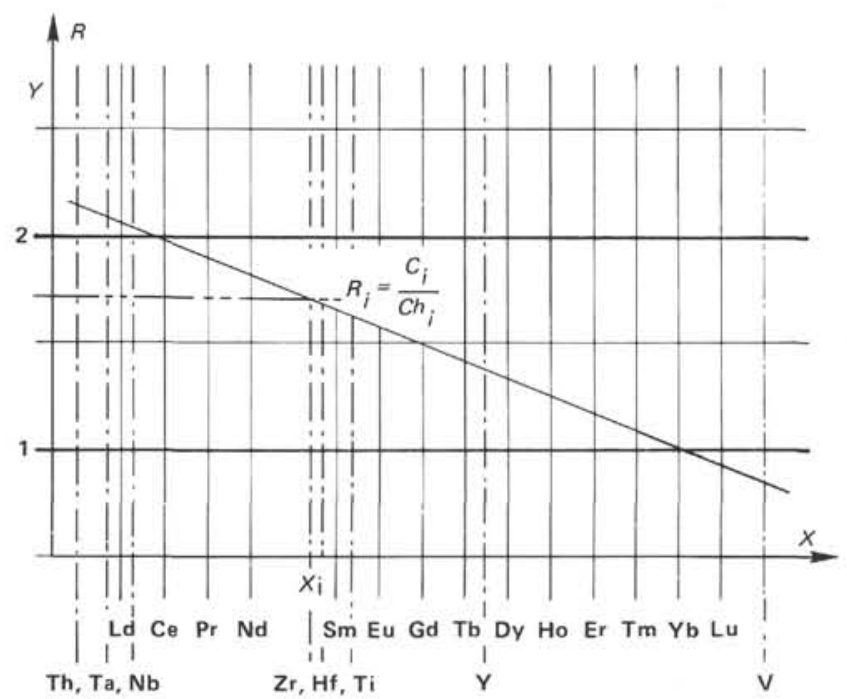

Figure 3. Determination of the position of an hygromagmaphile element ( $x$ axis) in respect to rare earth elements, from its normalized concentration in an "enriched" sample. On the $y$ axis is the logarithm of the normalized concentrations ( $R$ ).

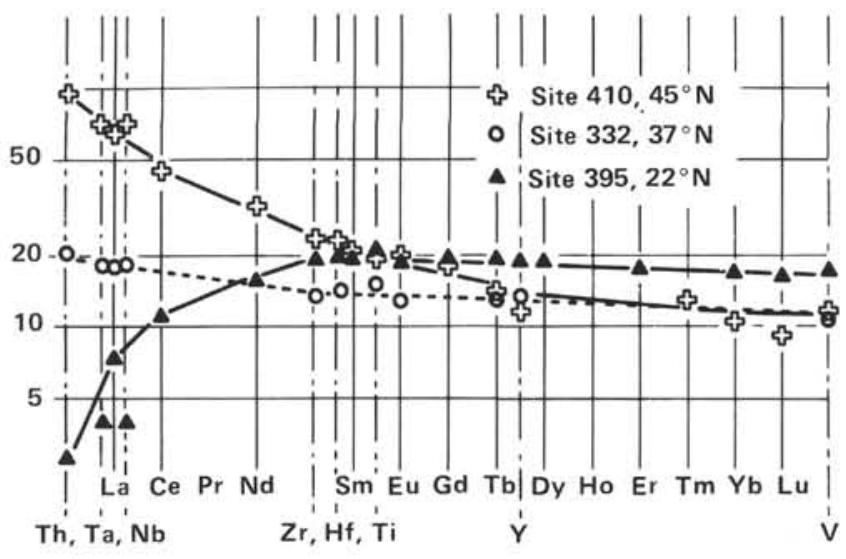

Figure 4. Typical examples showing "extended" Coryell-Masuda plot for enriched, flat, and depleted patterns.

We define thus the hygromagmaphile degree $\emptyset$ by the following relationship:

$$
\emptyset=\mathrm{a}\left(\Delta R_{\mathrm{i}}^{2}+1\right) n / R_{\mathrm{i}},
$$

where $\Delta R_{\mathrm{i}}$ corresponds to the difference of radii between the hygromagmaphile element and the substituted major element. The square of this difference is used to keep $\emptyset$ positive and to indicate that the difficulty of entering into a crystal structure increases probably much more quickly than linearly. $n / R_{\mathrm{i}}$ is the ionic potential; $n$ is the charge and $R_{\mathrm{i}}$ the ionic radius of the hygromagmaphile element.

In the case of identity of ionic radii between hygromagmaphile elements and major elements $\left(\Delta R_{\mathrm{i}}=0\right)$, the relationship must indicate possible variations with ionic potentials. This observation requires an equation such as that above. The parameter a is calculated from two elements that have, for example, the same behavior, but different $n$ and $R_{\mathrm{i}}$. The results (Table 1) show that the hygromagmaphile degree $\emptyset$ allows classification of the elements in almost the same order as obtained through comparative geochemistry. This table shows that the oxidation state for $\mathrm{V}$ is probably not +5 , because this assumption would make it the most hygromagmaphile element.

This classification of hygromagmaphile elements and the extended Coryell-Masuda plot will not be valid for all types of rocks. For example, because of possible differences in oxidation states and valencies of some elements, some fractionation would be expected during magmatic processes that would induce anomalies in the diagrams, similar to Eu anomalies (El Azzouzi et al., 1982). For tholeiites and Alkali basalts, this classification and the related extended Coryell-Masuda plot avoids misinterpretations caused by ignorance of comparative properties of the elements. In this respect, for instance, the distinction between Ti-rich and Ti-poor basalts should be disregarded; as is generally the case, a classification of rock types cannot be made on a single absolute value of one element. Ti is one of the hygromagmaphile elements. Because of the possibility of crossing patterns of REEs and the position of Ti (close to Sm), one can find 
Table 1. Ionic radii $(R)$, charges $(n)$, and calculated parameter $\phi$ (hygromagmaphile degree) for hygromagmaphile transition elements whose external shells of ions are the same as rare gas.

\begin{tabular}{lccc}
\hline Element & $R(\AA)$ & $n$ & $\phi$ \\
\hline $\mathrm{Th}$ & 0.99 & 4 & 8.34 \\
$\mathrm{La}$ & 1.06 & 3 & 7.35 \\
$\mathrm{Ta}$ & 0.68 & 5 & 7.25 \\
$\mathrm{Nb}$ & 0.69 & 5 & 7.35 \\
$\mathrm{Ce}$ & 1.03 & 3 & 6.90 \\
$\mathrm{Pr}$ & & & \\
$\mathrm{Nd}$ & 0.99 & 3 & 6.33 \\
$\mathrm{Zr}$ & 0.79 & 4 & 5.74 \\
$\mathrm{HF}$ & 0.79 & 4 & 5.74 \\
$\mathrm{Sm}$ & 0.96 & 3 & 5.89 \\
$\mathrm{Ti}$ & 0.68 & 4 & 5.88 \\
$\mathrm{Eu}$ & 0.95 & 3 & 5.71 \\
$\mathrm{Gd}$ & 0.94 & 3 & 5.56 \\
$\mathrm{~Tb}$ & 0.92 & 3 & 5.37 \\
$\mathrm{Y}$ & 0.92 & 3 & 5.34 \\
$\mathrm{Dy}$ & 0.90 & 3 & 5.16 \\
$\mathrm{Ho}$ & & 3 & \\
$\mathrm{Er}$ & 0.88 & 3 & 4.93 \\
$\mathrm{Tm}$ & & 3 & \\
$\mathrm{Yb}$ & 0.86 & 3 & 4.72 \\
$\mathrm{Lu}$ & 0.85 & 3 & 4.64 \\
$\mathrm{~V}$ & 0.59 & 5 & 9.23 \\
\hline
\end{tabular}

Note: $\operatorname{Pr}$ row is blank because it is not a natural element. Other blanks indicate that analytical data were not available.

Ti-rich basalts depleted in light REEs and Ti-poor basalts rich in light REEs. No more importance should be credited to absolute concentrations of Ti than to absolute concentrations of $\mathrm{Sm}$. This classification and the extended Coryell-Masuda plots will help us to find the anomalies of some elements (i.e., $\mathrm{Ti}$ and $\mathrm{V}$ when opaques start to crystallize; El Azzouzi et al., 1982) and to choose elements other than REEs for the identification of enriched and depleted material. This approach was used during the MAPCO cruise of Jean Charcot in 1979 (Bougault and Treuil, 1980) and during Leg 82 of the Glomar Challenger for analyses of $\mathrm{Nb}, \mathrm{Zr}, \mathrm{Ti}, \mathrm{Y}$, and $\mathrm{V}$ on board by X-ray fluorescence spectrometry. Details of the analytical procedures appear in another article (Etoubleau et al., this volume).

\section{HYGROMAGMAPHILE ELEMENTS: ZERO-AGE VARIATION BETWEEN AZORES TRIPLE JUNCTION AND $10^{\circ} \mathrm{N}$}

On the basis of theoretical considerations and models of magmatic processes (such as partial melting and fractional crystallization), we concluded that the basalts produced in the FAMOUS area $\left(36^{\circ} \mathrm{N}\right)$ (including samples recovered at Site 332 during Leg 37 [Aumento, Melson, et al., 1977] and the basalts produced at $22^{\circ} \mathrm{N}$ [Sites 395 and 396 of Legs 45 and 46 and zero-age samples]) were from two different mantle sources (Bougault, Cambon, et al., 1978; Bougault, Treuil, et al., 1978; Bougault, Joron, et al., 1979). The La/Ta ratio (2 very hygromagmaphile elements) defines distinct values in these two areas:
$\mathrm{La} / \mathrm{Ta}=9$ at $36^{\circ} \mathrm{N}, \mathrm{La} / \mathrm{Ta}=18$ at $22^{\circ} \mathrm{N}$. This interpretation was supported by isotopic data (Dupré and Allègre, 1980). These values of the $\mathrm{La} / \mathrm{Ta}$ ratio were thought to be characteristic of two mantle sources because one or the other value is found in several other places. For example, the value 9 (or 1 for the chondrite-normalized ratio) was found for the Reykjanes Ridge (Sites 407-409, Wood, Tarney, et al., 1979; Wood, Varet, et al., 1979), at $45^{\circ} \mathrm{N}$ on the Mid-Atlantic Ridge, and on the Emperor Seamount Chain (Leg 55; Cambon et al., 1980); the value 18 ( 2 for the normalized ratio) was found at $25^{\circ} \mathrm{N}$ for 110-Ma-old crust (Megaleg 51-53; Joron et al., 1980) and on the East Pacific Rise (Sites 482, 483 of Leg 65 at $21^{\circ} \mathrm{N}$; Cambon et al., 1983). This observation is illustrated in Figure 5. The value 1 for the normalized $\mathrm{La} / \mathrm{Ta}$ ratio is observed for normalized concentrations of $\mathrm{La}$ and Ta varying between 10 to more than 60 , whereas the value 2 for this ratio (or 0.5 for $\mathrm{Ta} / \mathrm{La}$ as plotted in Fig. 5) occurs mainly at low normalized concentrations of these elements (generally lower than 10). The La/Ta ratio for some dolerites of Morocco (Bertrand et al., 1982) and basalts from the Walvis Ridge (Bougault, 1980), which have high normalized concentrations, is also 2 ( 0.5 for $\mathrm{Ta} / \mathrm{La}$ ). This also supports the interpretation of $\mathrm{La} / \mathrm{Ta}$ ratios as indicative of mantle source characteristics, because values do not depend on the absolute concentration of the elements. Samples from dredge CH98 DR08 (Bougault and Treuil, 1980), whose $\mathrm{La} / \mathrm{Ta}$ ratio lies between the two values discussed above, could be interpreted as a result of a contribution from two mantle sources.

According to these observations and the data using the Coryell-Masuda diagrams defined in the previous paragraph, two types of pattern are observed for mid-ocean

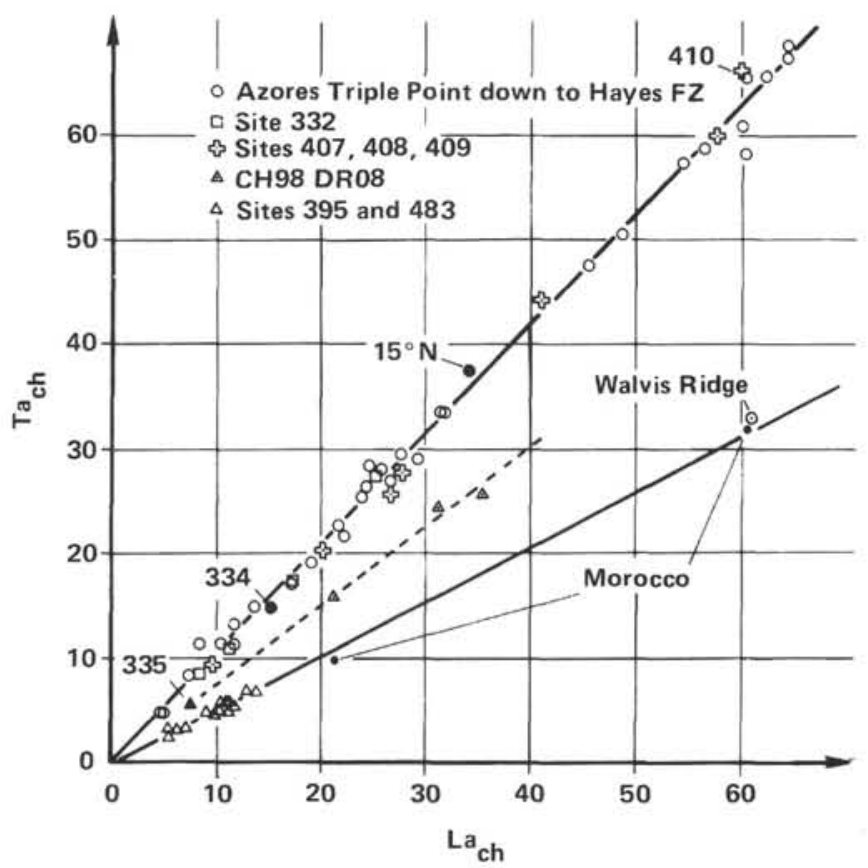

Figure 5. Normalized concentrations of tantalum versus normalized concentrations of lathanum. FZ = fracture zone. CH98 DR08 is a MAPCO station. 
ridge basalts (Fig. 4): for flat to enriched patterns, Ta and $\mathrm{Nb}$ plot at the same ordinate position as $\mathrm{La}$, but plot at a lower position than La (the factor two mentioned above for $\mathrm{La} / \mathrm{Ta}$ ratio) for depleted samples. We thus come to the notion of enrichment and depletion in light rare earth elements (LREE); in addition, a Nb-Ta anomaly is evident with respect to $\mathrm{La}$. Because $\mathrm{Nb}-\mathrm{Ta}$ and $\mathrm{La}$ are not fractionated for large variations in concentrations (Fig. 4), the two different $\mathrm{La}$ / Ta values (and the correlative $\mathrm{Ta}-\mathrm{Nb}$ anomaly) are thought to be representative of different mantle sources.

Schilling (1975) postulated his Azores mantle blob model from a large set of data obtained from samples dredged along the ridge axis between the Azores Triple Junction and $30^{\circ} \mathrm{N}$. Based on $\mathrm{La} / \mathrm{Sm}$ ratios, and confirmed by Sr isotope data (White et al., 1976; White and Schilling, 1978), the influence of the Azores mantle blob along the ridge axis at zero-age was shown to extend as far south as $33^{\circ} \mathrm{N}$. Detailed study of the ridge axis at $36^{\circ} \mathrm{N}$ during the FAMOUS expedition and after Leg 37 at $36^{\circ} \mathrm{N}$ and Legs 45 and 46 at $22^{\circ} \mathrm{N}$ indicated that this area of the North Atlantic was a good region to study the influence of a mantle plume or blob both along strike and also versus time. In 1977, on the VEMA cruise of the Jean Charcot, we obtained dredge material in this area and designed a cruise specifically devoted to dredging zero-age basalts in 1979 (the MAPCO cruise by the same research vessel). The objectives of that cruise were (1) to improve the sampling density between the Azores Triple Junction and $30^{\circ} \mathrm{N}$ (Schilling, 1975) and (2) to complete sampling south of $30^{\circ} \mathrm{N}$ in order to see to what extent the depleted character was constant south of $33^{\circ} \mathrm{N}$ (Bougault and Treuil, 1980).

Using the XRF analytical facilities on board (Bougault and Cambon, 1973), $\mathrm{Nb}, \mathrm{Zr}, \mathrm{Ti}$, and $\mathrm{Y}$ abundances were determined during the cruise to ascertain the enriched or depleted character of dredged materials (Bougault and Treuil, 1980). Onshore data obtained subsequent to the cruise confirmed the on-board results. The trace element data obtained both by XRF and NAA are given in (Appendix A at the end of this chapter). All Schilling's data are confirmed between the Azores Triple Junction and $30^{\circ} \mathrm{N}$. As examples, Figure 6 shows enriched basalts from the Triple Junction and Figure 7 shows depleted material from south of $30^{\circ} \mathrm{N}$. The ratios of hygromagmaphile element concentrations normalized to chondrites and including Schilling's data (Schilling, 1975) are shown in Appendix B (at the end of this chapter). La/Sm ratios are given for our data because $\mathrm{Sm}$ is not measured on a routine basis (Jaffrezic et al., 1977). Instead of the normalized $\mathrm{La} / \mathrm{Sm}$ ratio, the normalized $\mathrm{La} / \mathrm{Ti}$ ratio is presented for our data in Appendix B. From our study of the classification of hygromagmaphile elements, these two ratios should be about identical if no opaque minerals have been removed from the liquid). This condition is easily verified; in an extended Coryell-Masuda plot the normalized concentration of Ti must lie on the continuous REE pattern, including $\mathrm{Zr}$ and $\mathrm{Hf}$ (which plot close to Sm). In Appendix B we have also indicated the chondrite-normalized ratios of $\mathrm{Ta} / \mathrm{Hf}$ (which is about identical to $\mathrm{Nb} / \mathrm{Zr}$ ) and of $\mathrm{La} / \mathrm{Ta}$. The logarithms of $\mathrm{La} / \mathrm{Sm}$,
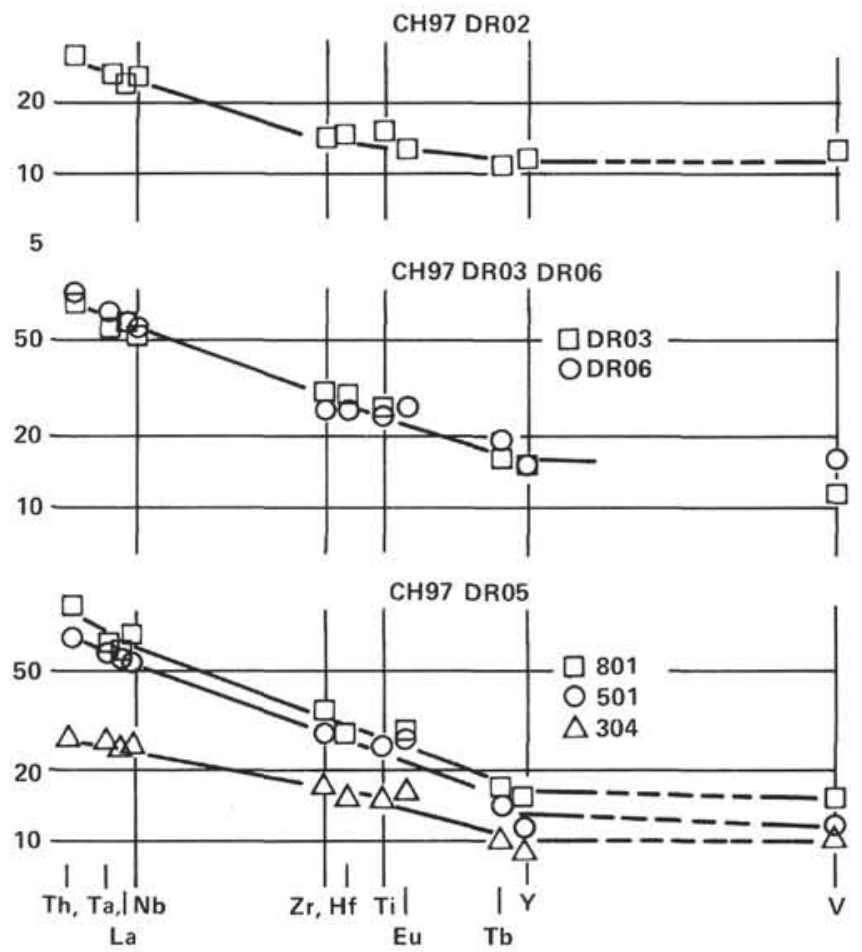

Figure 6. MAPCO cruise (Bougault and Treuil, 1980): extended Coryell-Masuda plot. Examples of typical enriched patterns in the Azores Triple Junction Area.
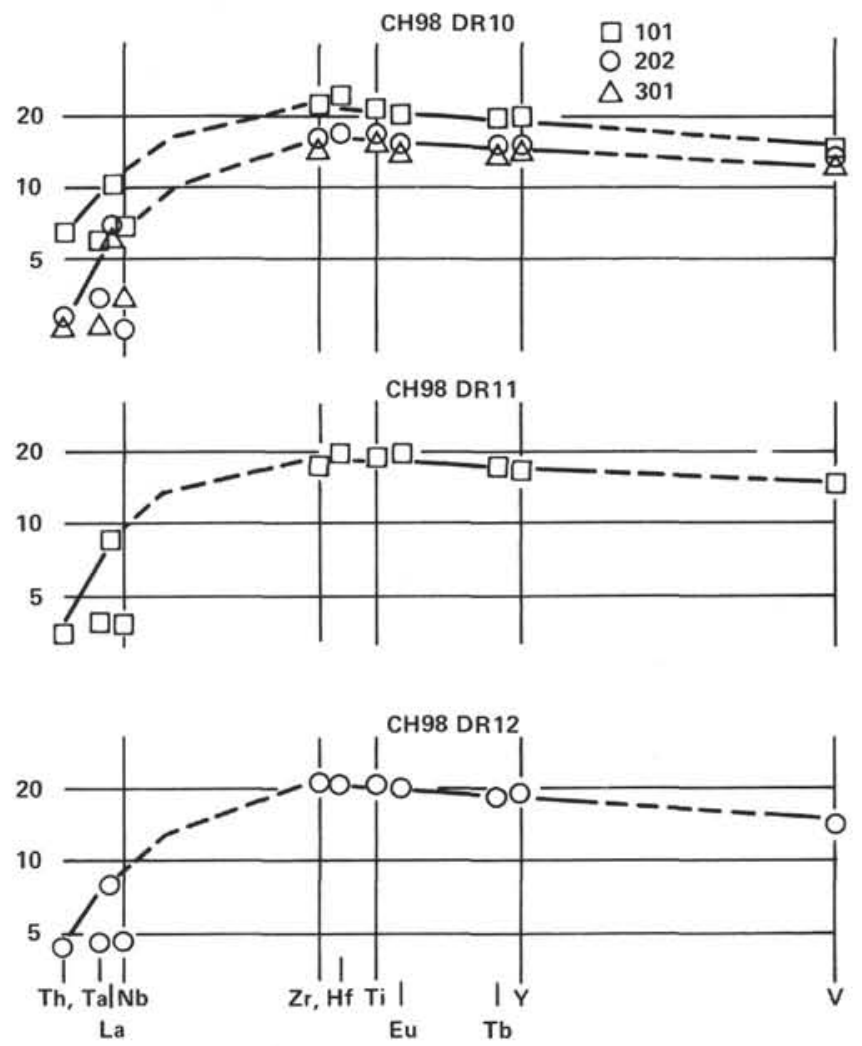

Figure 7. MAPCO cruise (Bougault and Treuil, 1980): extended Coryell-Masuda plot. Examples of typical depleted patterns south of $30^{\circ} \mathrm{N}$, zero-age Mid-Atlantic Ridge. Note the Ta- $\mathrm{Nb}$ "anomaly," compared to Azores Triple Junction area in Figure 6. See text for further discussion. 
$\mathrm{La} / \mathrm{Ti}$, and $\mathrm{Ta} / \mathrm{Hf}(\mathrm{Nb} / \mathrm{Zr})$ are plotted in Figure 8 . There are two reasons for plotting the logarithm instead of the ratio itself: the figure (1) preserves the importance of the ratios independently of their order of magnitude and (2) shows the differences observed for two elements in a Coryell-Masuda plot. Appendix B and Figure 8 clearly show the same results, confirming both a clear boundary at the level of Hayes Fracture Zone and the similarity of $\mathrm{La} / \mathrm{Sm}$ (Schilling's data) and $\mathrm{La} / \mathrm{Ti}$ (our data). $\mathrm{Ta} /$ $\mathrm{Hf}(\cong \mathrm{Nb} / \mathrm{Zr})$ ratios also give the same information. Looking in more detail at Figure 8, one can make the following observations:

1. A range of variation of the ratios can be observed in a single dredge haul.

2. The differences in $\mathrm{Ta} / \mathrm{Hf}(\mathrm{Nb} / \mathrm{Zr})$ north and south of the Hayes Fracture Zone are larger than the differences in $\mathrm{La} / \mathrm{Sm}$ or $\mathrm{La} / \mathrm{Ti}$ ratios. This can easily be explained by the behavior of $\mathrm{Ta}(\mathrm{Nb})$ compared to $\mathrm{La}$.

3. South of the Hayes Fracture Zone, the values of MAPCO CH98 DR08 resemble values to the north, confirming the results obtained on board (Bougault and Treuil, 1980).

4. The correlation between hygromagmaphile element ratios and the filtered bathymetry (Le Douaran and Francheteau, 1981) is obvious and confirms the observations of Schilling (1975).

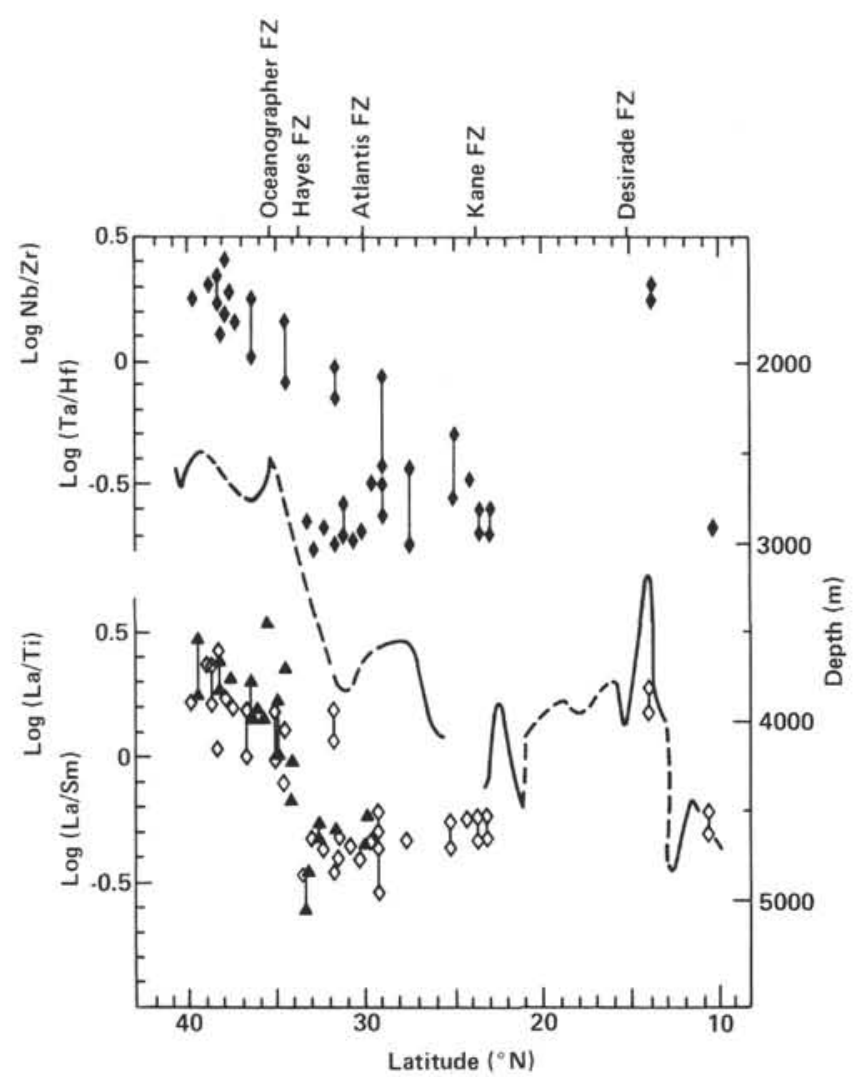

Figure 8. Logarithms of hygromagmaphile element ratios plotted versus latitude from the Azores Triple Junction to $10^{\circ} \mathrm{N}$. The zero-age filtered depth indicated is from Le Douaran and Francheteau (1981). Filled diamonds correspond to the upper parameters (either $\log [\mathrm{Nb} /$ $\mathrm{Zr}]$ or $\log [\mathrm{Ta} / \mathrm{Hf}])$; open diamonds correspond to $\log (\mathrm{La} / \mathrm{Ti})$ (author's data); filled triangles correspond to $\log (\mathrm{La} / \mathrm{Sm})$ (data from Schilling, 1975). FZ = fracture zone.
5. Farther to the south, values characteristic of the Azores area are observed for a topographic high at zeroage at $14^{\circ} \mathrm{N}$.

The normalized $\mathrm{La} / \mathrm{Ta}$ ratios (Appendix $\mathrm{B}$ ) are close to 1 for the Azores Triple Junction to the Hayes Fracture Zone. South of the Hayes Fracture Zone, many of the values for this ratio are around 2, corresponding to the value typical of depleted MORB, but several values for this ratio are between 1 and 2. This is shown in Figure 9; samples recovered south of the Hayes Fracture Zone lie between the lines whose slopes are 1 and 0.5 (for $\mathrm{Ta}$ / La). Samples from CH98 DR08 also clearly lie between the two lines; the two types of samples in this dredge are confirmed by $\mathrm{Pb}$ isotope data (Dupré, 1982, pers. comm.). The variation in $\mathrm{La} / \mathrm{Ta}$ ratio could then be tentatively interpreted in terms of mixing of two end members characterized by normalized $\mathrm{La} / \mathrm{Ta}$ ratios of 1 and 2 . An alternative interpretation could be continuous fractionation of $\mathrm{La}$ and $\mathrm{Ta}$ (or $\mathrm{Nb}$ ), similar to $\mathrm{La}$ and $\mathrm{Ce}$ ( $\mathrm{Ta}$ has a behavior closer to $\mathrm{La}$ than $\mathrm{Ce}$ ). For clearer understanding of this "Nb-Ta" anomaly with respect to $\mathrm{La}$, we need more data obtained from different geologic settings (i.e. Dupuy et al., 1982; Briqueu et al., in press).

\section{LEG 82 COMPARATIVE GEOCHEMISTRY: ANALYTICAL RESULTS AND EXTENDED CORYELL-MASUDA PLOTS}

To document mantle heterogeneity away from the present Azores Triple Junction versus time and along isochrons, a grid composed of 11 potential sites was prepared ahead of time. The sites were chosen to lie along flow lines (1) passing through the Azores Triple Junction, (2) passing through the FAMOUS area and the sites drilled

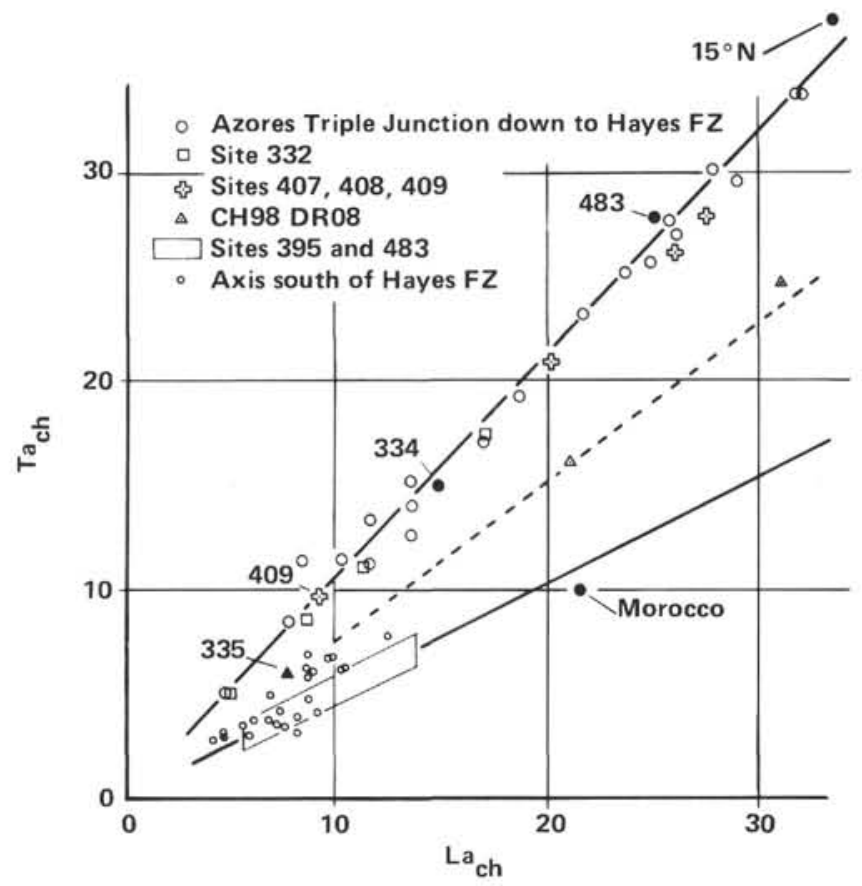

Figure 9. Normalized concentrations of tantalum versus normalized concentrations of lanthanum (as in Figure 5). Details for low values, specifically for dredged samples at zero age south of Hayes Fracture Zone. FZ = fracture zone. 
on Leg 37 (Sites 332, 334, 335), and (3) straddling the Hayes Fracture Zone; they were located on Magnetic Anomalies 6, 13, and 24. The selection of these sites had to be made on board on the basis of the concentrations of hygromagmaphile elements measured by XRF analysis ( $\mathrm{Nb}, \mathrm{Zr}, \mathrm{Ti}, \mathrm{Y}$, and $\mathrm{V}$ ) (Etoubleau et al., this volume). We wanted to be somewhat consistent in the number of sites along isochrons and flow lines in order to obtain a representative regional picture. Actually, the selection was critical for the first two or three sites, because then the other sites had to be selected for consistency with both isochrons and flow lines. So, after we found depleted material at Site 556 (Azores flow line, Anomaly 5), we had to choose the other sites along other flow lines on the same isochrons (Anomalies 5 and 13) to produce a coherent distribution of sites. The final picture of the drilled sites during Leg 82 is presented in Figure 10. Before interpreting the results in terms of magmatic processes and mantle heterogeneity, we will discuss the classification of hygromagmaphile elements and the correlative extended Coryell-Masuda plot.

Trace element data obtained by XRF (either on board or on shore) and by NAA are presented in Appendix C as average concentrations for each chemical group. Data, sample by sample, are given in the Appendix at the end of this volume. As far as chemical data can be used as discriminant parameters to distinguish the different basaltic units encountered in each hole, onshore results have confirmed shipboard data. The classification into different chemical groups proposed in the site chapters is not modified. A standard deviation related to each average concentration (Appendix C) is given when the chemical group is defined by more than two samples. The sig- nificance of these standard deviations depends on the behavior of the element itself and on the analytical procedure. For example, alteration processes are not taken into consideration for the definition of a chemical group. As a consequence the standard deviation includes both the alteration effect and the analytical precision (e.g., $\mathrm{Rb}, \mathrm{Cs})$. Elements that are not affected by alteration have standard deviations for each chemical group that reflect the analytical precision. The standard deviations of $\mathrm{Nb}$ are less than one, except for 1.2 for Chemical Group IV of Hole 558; this result confirms the precision expected from the analytical work (Etoubleau et al., this volume).

Figure 11 is an example of an extended REE plot that was made on board during Leg 82 . Figure 12 summarizes all results obtained during Leg 82 , including onshore data. These figures will be used for the discussion of the results of Leg 82 .

1. Elements of first and second column of the classification of the elements. These elements should not be included in an extended REE plot because of their sensitivity to alteration processes. The best example of the effect of low temperature alteration on alkali elements was obtained during Legs 51 and 52 at Sites 417 and 418 (Joron et al., 1979; Bougault, Joron, et al., 1979). The Rb concentration, which is lower than $1 \mathrm{ppm}$ in unaltered samples, reaches $60 \mathrm{ppm}$ in altered samples. Even in fresh samples or samples that appear fresh based on thinsection observations, the effect of contamination of alkali elements by low-temperature alteration is also apparent. An example was given during Leg 45 at Site 395 (Bougault, Joron, et al., 1979), where Rb concentration varies from values lower than $1 \mathrm{ppm}$ up to $5 \mathrm{ppm}$ and Cs

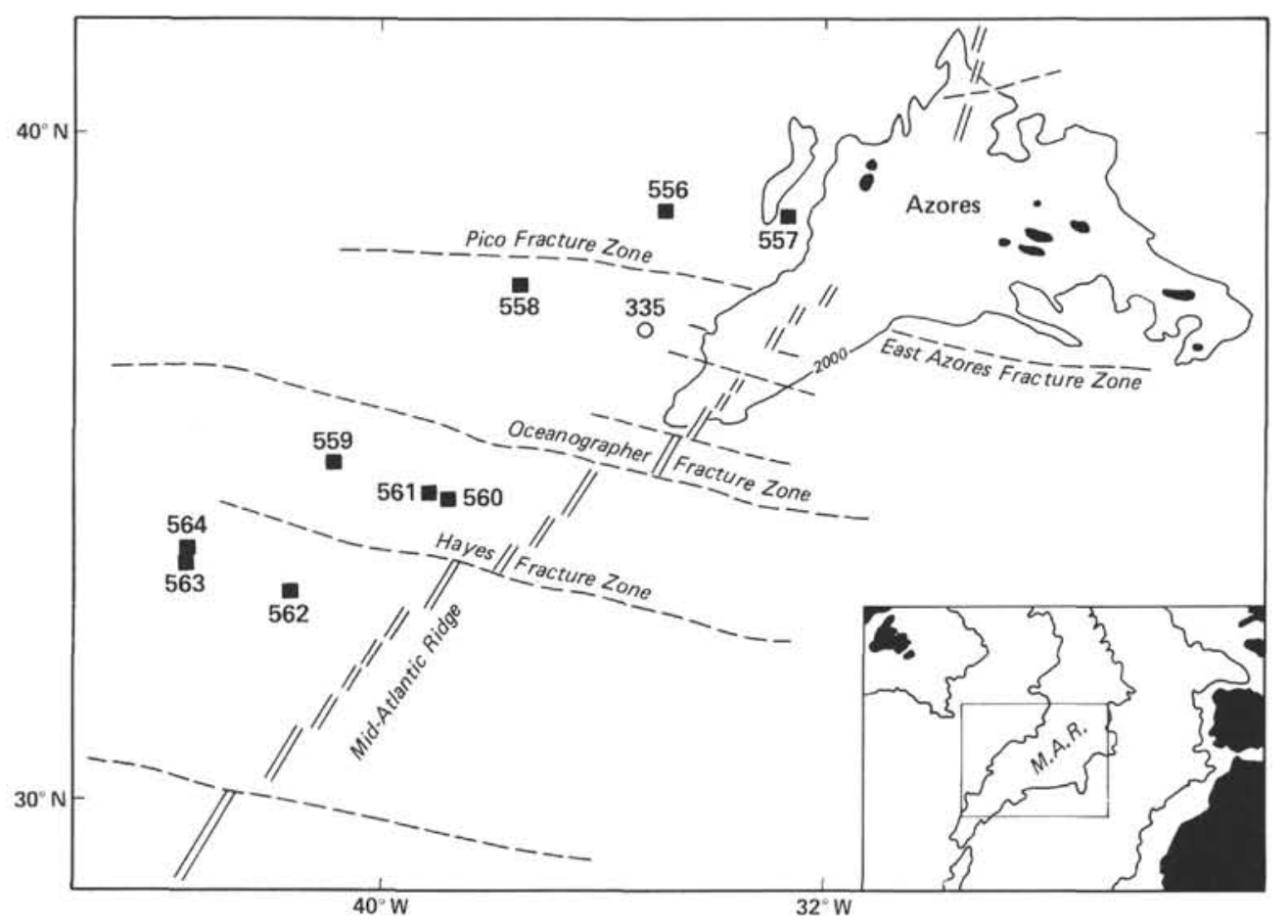

Figure 10. Locations of sites drilled during Leg 82. 


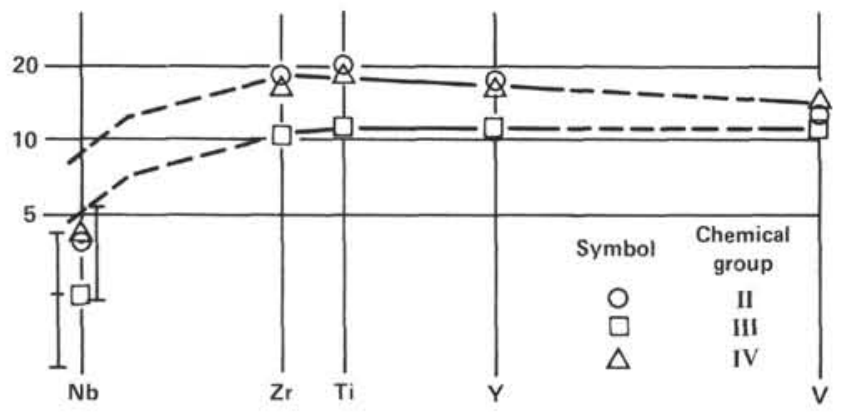

Figure 11. Extended Coryell-Masuda plot obtained on board for Hole 556. Between $\mathrm{Zr}$ and $\mathrm{Nb}$, the line was tentatively drawn by assuming a factor two between normalized $\mathrm{La}$ and $\mathrm{Nb}$ concentrations. This assumption, deduced from previous studies, was shown to be correct (see Fig. 12).

from values lower than $0.02 \mathrm{ppm}$ up to $0.2 \mathrm{ppm}$. Data obtained during Leg 82 provide additional information. Figure 13 shows the variations of $\mathrm{K}, \mathrm{Cs}$, and $\mathrm{Sr}$ versus $\mathrm{Rb}$ in hole 562. The correlation between alkali elements shows coherent behavior of these elements during alteration, as expected from their chemical properties; but it is almost impossible to deduce the values for unaltered basalts from these plots. $\mathrm{Sr}$ concentrations vary between 85 and $115 \mathrm{ppm}$ : the absence of correlation with $\mathrm{Rb}$ tends to confirm the difference of behavior of $\mathrm{Sr}$ and alkali elements that was observed at Sites 417-418 (Legs 51-52; Bougault, Joron et al., 1979). The contamination in $\mathrm{Sr}$ is also shown by $\mathrm{Sr}$ isotopic data (Rideout and Schilling, this volume); when samples are suitably treated, the alteration effect can be removed.

2. The pairs of elements that do not fractionate: $\mathrm{Nb} /$ $\mathrm{Ta}, \mathrm{Zr} / \mathrm{Hf}, \mathrm{Y} / \mathrm{Tb}$ - the relative positions of $\mathrm{Zr}, \mathrm{Hf}, \mathrm{Ti}$. Leg 82 provides an interesting regional set of data that covers almost the entire spectrum of enrichment and depletion in LREEs (Fig. 12). Some hygromagmaphile elements behave in such identical ways that they should be located at the same position (x axis) in an extended Coryell-Masuda plot. Because of the range of variation that is shown by Leg 82 results, we can test the nonfractionation of some elements. Figure 14 shows that the $\mathrm{Nb} / \mathrm{Ta}$ ratio remains constant $(\mathrm{Nb} / \mathrm{Ta}=16)$ for a factor-30 variation in concentration. This is confirmation that $\mathrm{Nb} / \mathrm{Ta}$ is constant in all basalts at the surface of the earth, and it probably represents the best value for the Earth's mantle and chondrites (Bougault, Joron, et al., 1979). Very little fractionation is observed for $\mathrm{Zr} / \mathrm{Hf}$ and $\mathrm{Y} / \mathrm{Tb}$ ratios (Fig. 15). For $\mathrm{Zr} / \mathrm{Hf}$, we note that the ratio $\mathrm{Zr} / \mathrm{Hf}$ tends to increase somewhat from the most depleted samples to enriched samples: this observation confirms that $\mathrm{Zr}$ is probably a little more hygromagmaphile than $\mathrm{Hf}$ and has to be plotted on the left of Hf. The depleted samples (Site 556) tend to have $\mathrm{Zr} / \mathrm{Hf}$ ratios (35) closer to the chondritic ratio (Shima, 1979) than flat to enriched samples, which have a $\mathrm{Zr} / \mathrm{Hf}$ ratio close to 40 . For $\mathrm{Y}$ and $\mathrm{Tb}$, the $\mathrm{Y} / \mathrm{Tb}$ ratio is constant for all samples except those of Hole 557. In Figure 16, the normalized concentrations of $\mathrm{Hf}$ are plotted versus normalized concentrations of Ti. This confirms the very similar behavior of $\mathrm{Hf}$ (and $\mathrm{Zr}$ ) and $\mathrm{Ti}$ and their position close to each other in an extended Coryell-Masuda plot. The Hf/ $\mathrm{Ti}$ ratio increases somewhat with concentration (except at Site 557), suggesting that $\mathrm{Hf}$ (and $\mathrm{Zr}$ ) are more hygromagmaphile than Ti. One sample from Hole 561 lies off the normal trend; this low value of $\mathrm{Ti}$ compared to $\mathrm{Hf}$ (and $\mathrm{Zr}$ ) is probably explained by some opaque phase removal (El Azzouzi et al., 1982).

3. The La/Ta ratio. The normalized concentrations of $\mathrm{La}$ are plotted versus normalized concentrations of $\mathrm{Ta}$ in Figure 17. The $\mathrm{La}$ / Ta normalized ratio is 1 for all chemical groups whose normalized concentrations are higher than 10. This is confirmation that $\mathrm{Ta}$ (and $\mathrm{Nb}$ ) have to be plotted at the same position as, or very close to, the La position in an extended Coryell-Masuda plot. All chemical groups of Site 556 (depleted character) have the ratio that has been found in many other areas, $(\mathrm{La} / \mathrm{Ta})_{\mathrm{ch}}$ $=2$. On board the ship, the extended Coryell-Masuda plots were drawn when only $\mathrm{Nb}, \mathrm{Zr}, \mathrm{Ti}, \mathrm{Y}$, and $\mathrm{V}$ analyses were available. It was assumed at Site 556 that the normalized $\mathrm{La} / \mathrm{Nb}$ (equivalent to $\mathrm{La} / \mathrm{Ta}$ ) ratio is equal to 2 to make the curve of the diagram pass through the predicted La position (Fig. 11). Onshore results show that this assumption was true (Fig. 12).

As is the case for many samples from south of the Hayes Fracture Zone (zero age), the other groups plot between the lines whose slopes are 1 and 2 (Fig. 17). For Sites 558 and 561 where both depleted and enriched material were found, the normalized $\mathrm{La} / \mathrm{Ta}$ ratio is 1 for enriched material and lies between 1 and 2 for depleted material. We do not know at the moment if such a variation of the $\mathrm{La} / \mathrm{Ta}$ ratio can be interpreted as continuous fractionation of two elements whose behavior is very similar but not identical, or if the intermediate ratios can be considered the result of mixing of two end-members characterized by normalized La/Ta ratio of 1 and 2 . Hole 564 provides interesting data. The range of variation of La and $\mathrm{Ta}$ are indicated in Figure 17. Only one chemical group was defined at that site, but whereas elements like $\mathrm{Ni}$ or $\mathrm{Cr}$ (which are very sensitive to crystallization processes) do not show any significant variation, a regular increase of $\mathrm{Zr}$ and $\mathrm{Nb}$ abundances downhole was noted on board (see site chapter, Site 564, this volume). Downhole, $\mathrm{Zr}$ and $\mathrm{Hf}$ increase by about $10 \%$. La increases by about $30 \%, \mathrm{Nb}$ and $\mathrm{Ta}$ by $50 \%$, and $\mathrm{Th}$ by $70 \%$. These variations define a range of extended Coryell-Masuda plots for which the largest variation corresponds to the most hygromagmaphile element (Th; Fig. 12). The relative variations of $\mathrm{La}$ and $\mathrm{Ta}$ (or $\mathrm{Nb}$ ) are not the same, so the normalized $\mathrm{La} / \mathrm{Ta}$ ratio varies from about 1.1 to 1.6. These data cannot be explained by fractional crystallization; it is also difficult to see how, downhole, the different basalt samples could be derived by different degrees of partial melting of the same source. One possible explanation would be the mixing in different proportions of two liquids derived from two mantle sources. This interpretation could apply for samples other than those of Hole 564, whose normalized La/Ta ratios lie between 1 and 2 .

The hypothesis that mixing of two mantle sources relates to observed variations of $\mathrm{La} / \mathrm{Ta}$ is not immediately apparent from Figure 18, in which the logarithm of ra- 

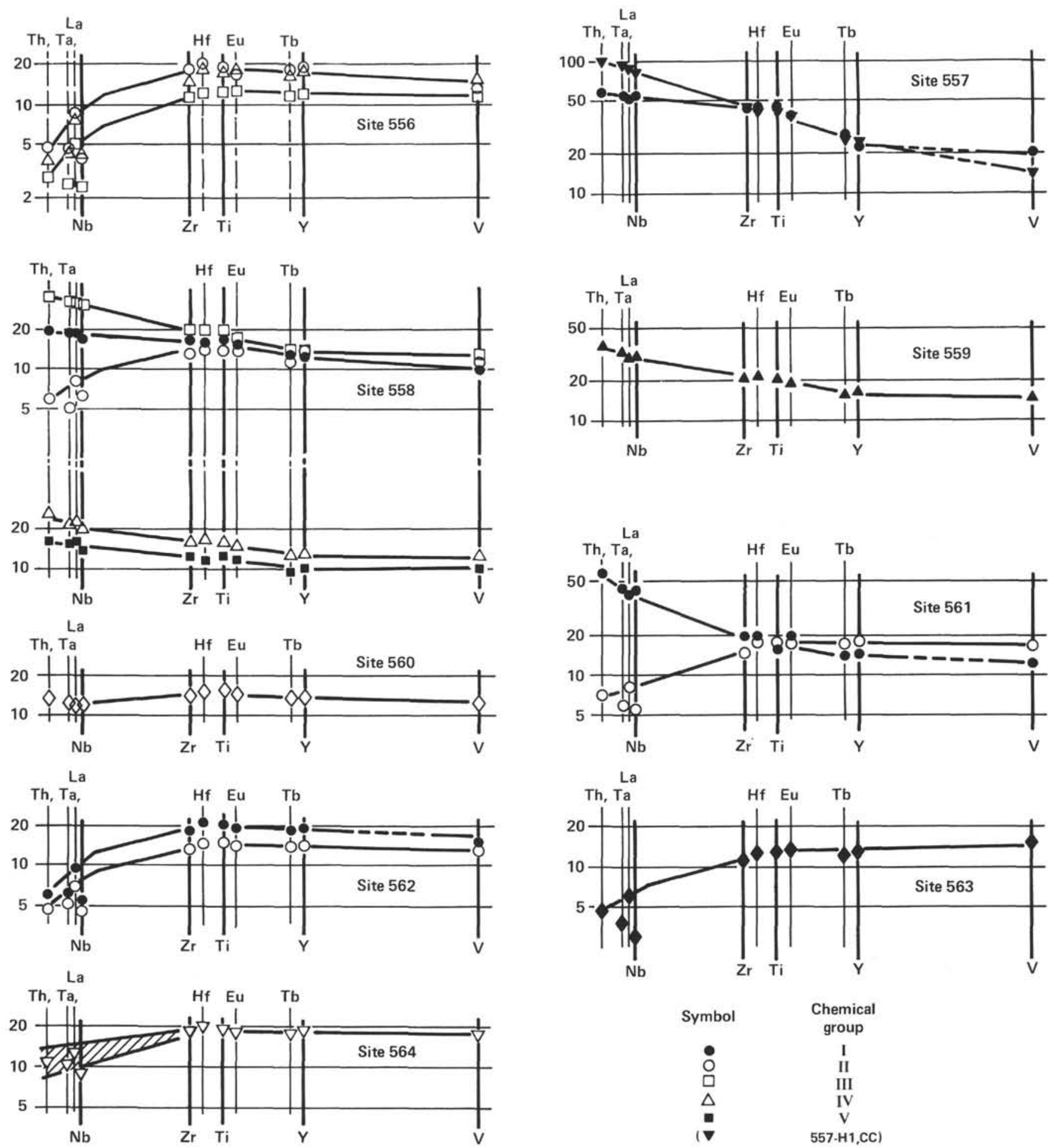

Figure 12. Extended Coryell-Masuda plots obtained for all Leg 82 sites, including on-board and onshore data.

tios involving the elements $\mathrm{Th}, \mathrm{Ta}, \mathrm{La}$, and $\mathrm{Hf}$ are plotted. For both plots on this figure we used the same element in the denominator of the ratios (La for the upper plot, Th for the lower plot). The similar continuity on both diagrams does not indicate that we should make a special case of $\mathrm{Ta} / \mathrm{La}$, compared to other ratios (e.g.,
$\mathrm{La} / \mathrm{Th}$ ). There are however, two reasons for keeping in mind the hypothesis of two mantle sources: (1) for enriched samples, the $\mathrm{La} / \mathrm{Ta}$ ratio remains constant (but $\mathrm{La} / \mathrm{Th}$ ratios are fractionated) and equal to the chondritic ratio $\left(\log (\mathrm{Ta} / \mathrm{La})_{\mathrm{ch}} \cong 0\right)$; magmatic processes should thus have very little effect upon this ratio; and 

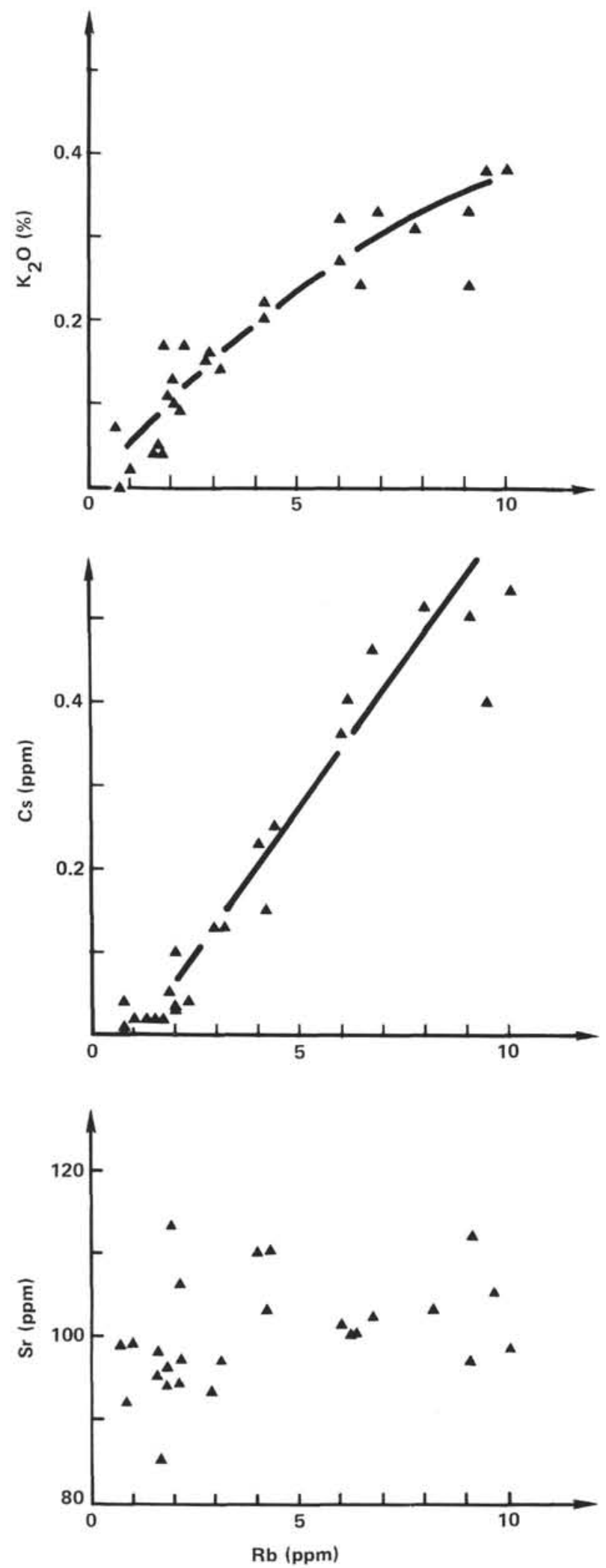

Figure 13. Site 562: potassium, cesium, and strontium versus rubidium.

(2) some samples (e.g., dolerites from Morocco and the Walvis Ridge (Fig. 5)) are enriched, have a Log (Ta/ La) $)_{\text {ch }}$ equal to -0.3 (like Hole 556), and do not plot on the trend of the upper diagram of Fig. 18, whereas they
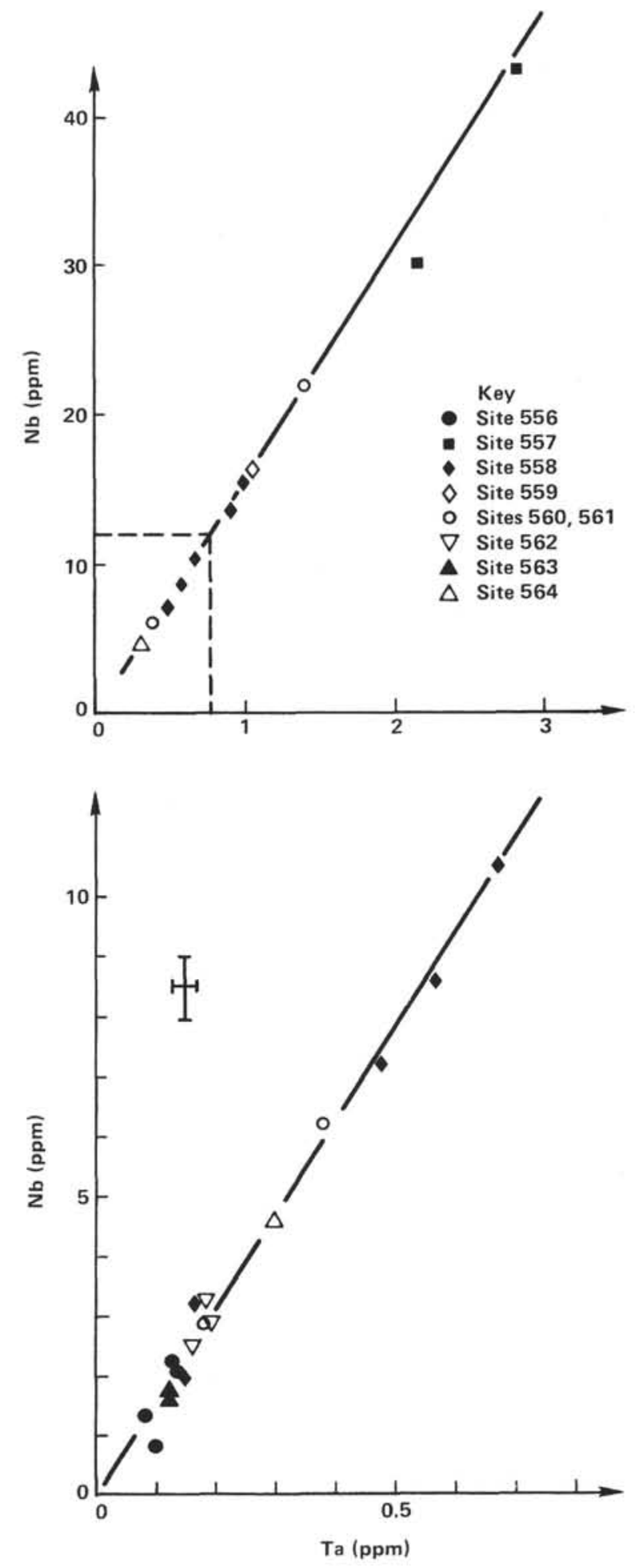

Figure 14. Niobium versus tantalum for Leg 82 sites.

plot on the continuous line in the lower diagram. In addition, basalts from subduction zones lying in the enriched field have $\log (\mathrm{La} / \mathrm{Ta})_{\text {ch }}$ that can be much lower $(-0.7$ to -1$)$ (Briqueu et al., in press; Dupuy et al., 1982).

These two reasons make it likely that $\mathrm{La}$ / Ta ratios reflect in part a mantle property, either chemical or mineralogic. 

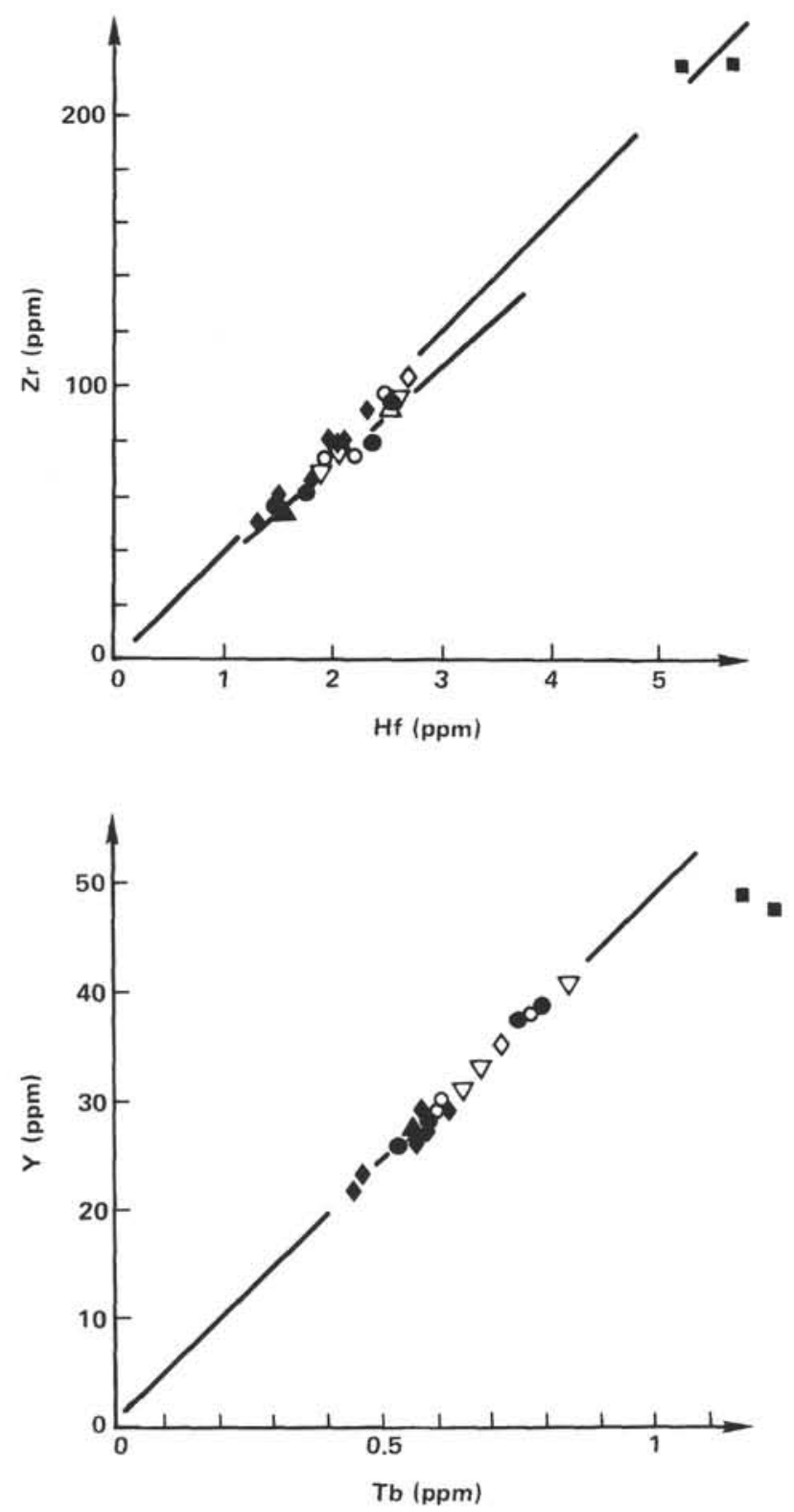

Figure 15. Zirconium versus hafnium, and yttrium versus terbium for Leg 82 sites. See Figure 14 for symbols.

\section{LEG 82, LOCAL VERSUS REGIONAL MANTLE HETEROGENEITIES: SHORT-TERM MAGMA CHAMBERS}

\section{“Crossing patterns": Local Mantle Heterogeneity and Short-term Magma Chambers}

Interesting "crossing patterns" of the REE plots and extended REE plots have been found at two Leg 82 sites, 558 and 561 . These crossing patterns are related to two types of extended Coryell-Masuda plots found at the same location: one of them is enriched in the most hygromagmaphile elements, the other is depleted. In addition, the normalized concentrations of the less hygromagmaphile elements of the enriched samples are somewhat lower than the normalized concentrations of the depleted samples. A typical example is given in Figure 12 for Site 561; the two extended REE plots cover al-

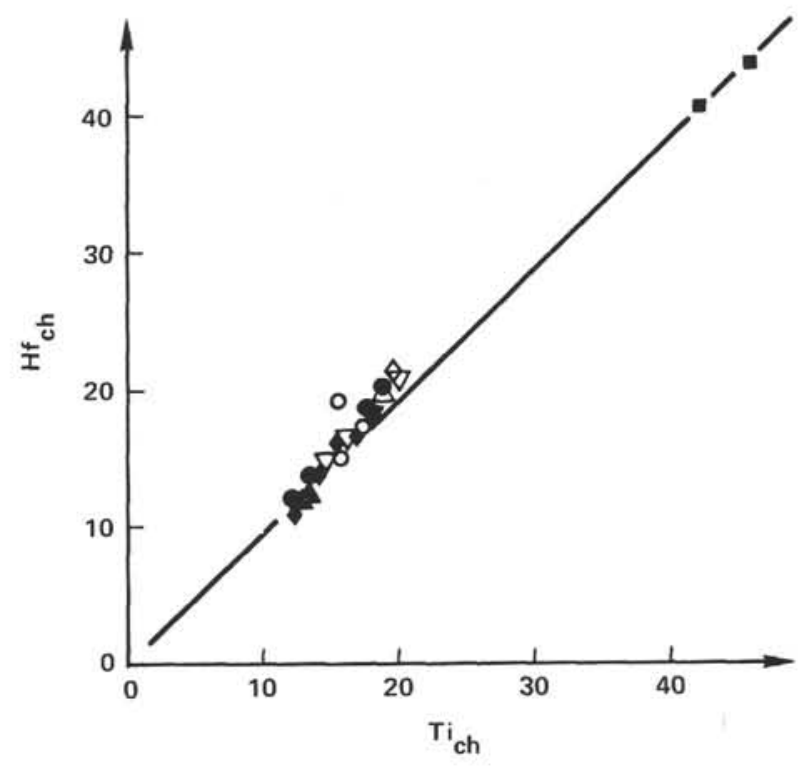

Figure 16. Normalized concentrations of hafnium versus normalized concentrations of titanium for Leg 82 sites. Symbols as in Figure 14.

most the entire spectrum of mid-ocean ridge basalts. Such crossing patterns found in the FAMOUS area, (presenting a narrower range than at Site 561) were discussed by Langmuir and others (1977) and were used as examples of possible results of dynamic melting. Such dynamic melting and other multistage melting models (Langmuir et al., 1977; Bougault, Cambon, et al., 1979; Bougault, 1980; Duncan and Green, 1980), when combined with crystallization effects (which increase all concentrations of hygromagmaphile elements in about the same proportion), can explain such distributions. However, without any real constraints on the degree of melting, it is always possible to find a model that fits the data, starting from a unique mantle source. Another feature presented by these crossing pattern is the $\mathrm{Ta}-\mathrm{Nb}$ anomaly with respect to $\mathrm{La}$, which has been tentatively interpreted as reflecting different mantle sources. For enriched samples, the $\mathrm{Ta}, \mathrm{Nb}$, and La normalized concentrations are about equal; for depleted samples $\mathrm{Ta}$ and $\mathrm{Nb}$ normalized concentrations are much lower than the La normalized concentration. Isotopic data provide limits for these interpretations.

At Site 561, isotopic ratios of $\mathrm{Nd}$ and $\mathrm{Pb}$ are very distinctive (Jenner et al., Dupré et al., Rideout and Schilling, all this volume): high $\mathrm{Pb}$ isotopic ratios $\left({ }^{206} \mathrm{~Pb} /{ }^{204} \mathrm{~Pb}\right.$ $\left.=19.53 ;{ }^{207} \mathrm{~Pb} / 204 \mathrm{~Pb}=15.59 ;{ }^{208} \mathrm{~Pb} / 204 \mathrm{~Pb}=39.25\right)$; and low ${ }^{143} \mathrm{Nd} /{ }^{144} \mathrm{Nd}$ ratio $(0.51298)$ correspond to the unit enriched in the most hygromagmaphile elements; low $\mathrm{Pb}$ isotopic ratios $\left({ }^{206} \mathrm{~Pb} /{ }^{204} \mathrm{~Pb}=18.83 ;{ }^{207} \mathrm{~Pb} /{ }^{204} \mathrm{~Pb}\right.$ $\left.=15.53 ;{ }^{208} \mathrm{~Pb} /{ }^{204} \mathrm{~Pb}=38.35\right)$ and high ${ }^{143} \mathrm{Nd} /{ }^{144} \mathrm{Nd}$ ratios $(0.51310)$ correspond to samples depleted in the most hygromagmaphile elements. This result has three important implications:

1. Two distinct mantle sources can contribute locally to the formation of the second layer of the oceanic crust.

2. Different extended Coryell-Masuda plots and Ta$\mathrm{Nb}$ anomalies observed in liquids can reflect different mantle sources. 

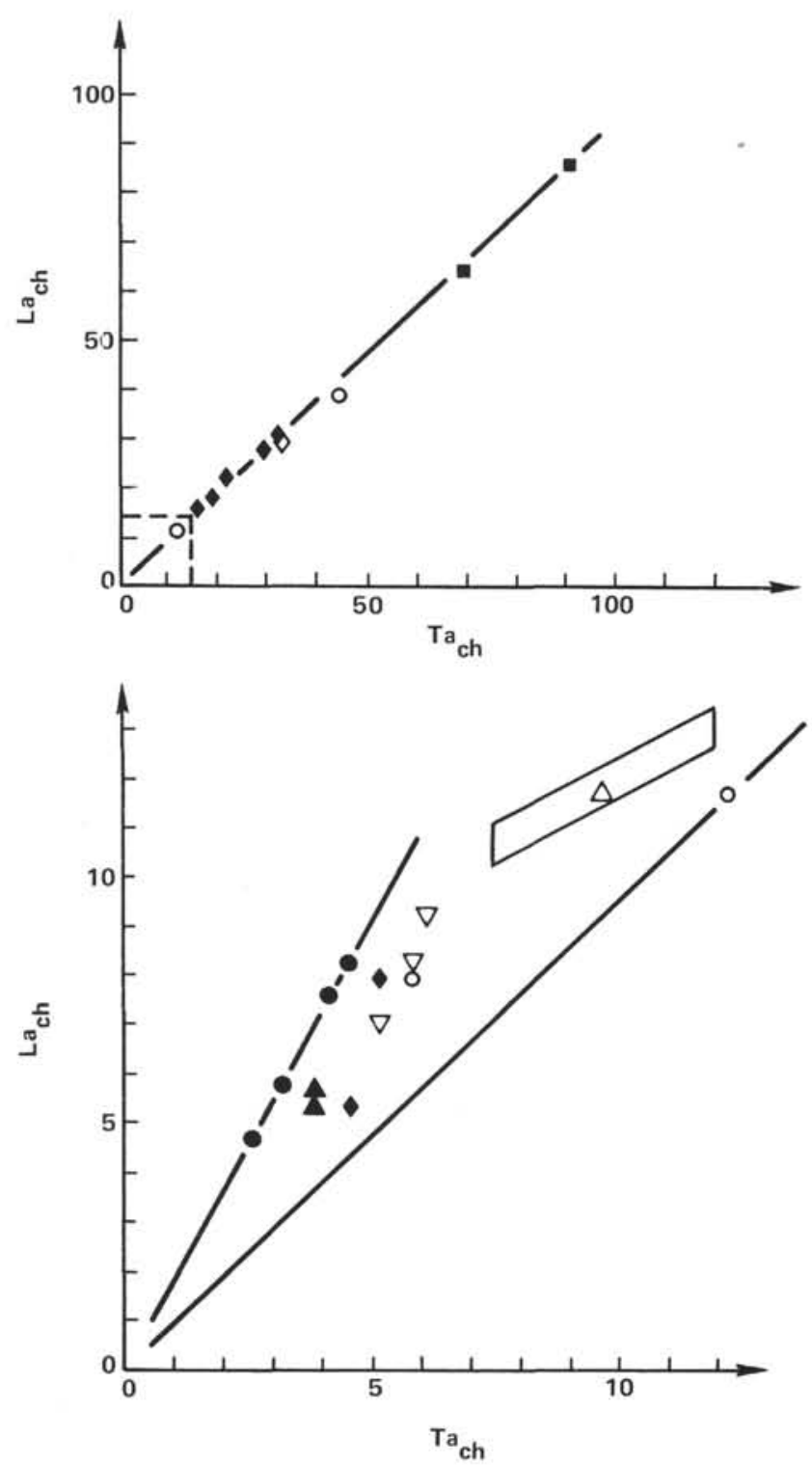

Figure 17. Normalized concentrations of lanthanum versus normalized concentrations of tantalum for Leg 82 sites. Symbols as in Figure 14. Parallelogram shows range of variation for Hole 564 .

3. Samples with such different trace element and isotopic characteristics in a single hole can only be generated in the context of small, isolated, short-term magma chambers.

At Site 558, differences in isotopic ratios are also observed between enriched and depleted samples. Chemical Group III (the most enriched in $\mathrm{Th}, \mathrm{Ta}, \mathrm{La}$, and $\mathrm{Nb}$ ) has the highest $\mathrm{Pb}$ isotopic ratios $\left({ }^{206} \mathrm{~Pb} /{ }^{204} \mathrm{~Pb}=20.25\right.$; $\left.{ }^{207} \mathrm{~Pb} /{ }^{204} \mathrm{~Pb}=15.63 ;{ }^{208} \mathrm{~Pb} /{ }^{204} \mathrm{~Pb}=39.64\right)$ and the lowest ${ }^{143} \mathrm{Nd} /{ }^{144} \mathrm{Nd}$ ratio $(0.51291)$, whereas Chemical Group II, (the most "depleted" in this hole) has the lowest $\mathrm{Pb}$ isotopic ratios $\left({ }^{206} \mathrm{~Pb} /{ }^{204} \mathrm{~Pb}=19.61 ;{ }^{207} \mathrm{~Pb} /{ }^{204} \mathrm{~Pb}=\right.$ $\left.15.60 ;{ }^{208} \mathrm{~Pb} /{ }^{206} \mathrm{~Pb}=39.17\right)$ and the highest ${ }^{143} \mathrm{Nd} /{ }^{144} \mathrm{Nd}$ ratio $(0.51296)$. The implications of Site 561 data (previously discussed) are confirmed by Site 558 data.

On the East Pacific Rise at about $22^{\circ} \mathrm{N}$, all samples are depleted MORB and have a normalized $\mathrm{La} / \mathrm{Ta}$ ratio
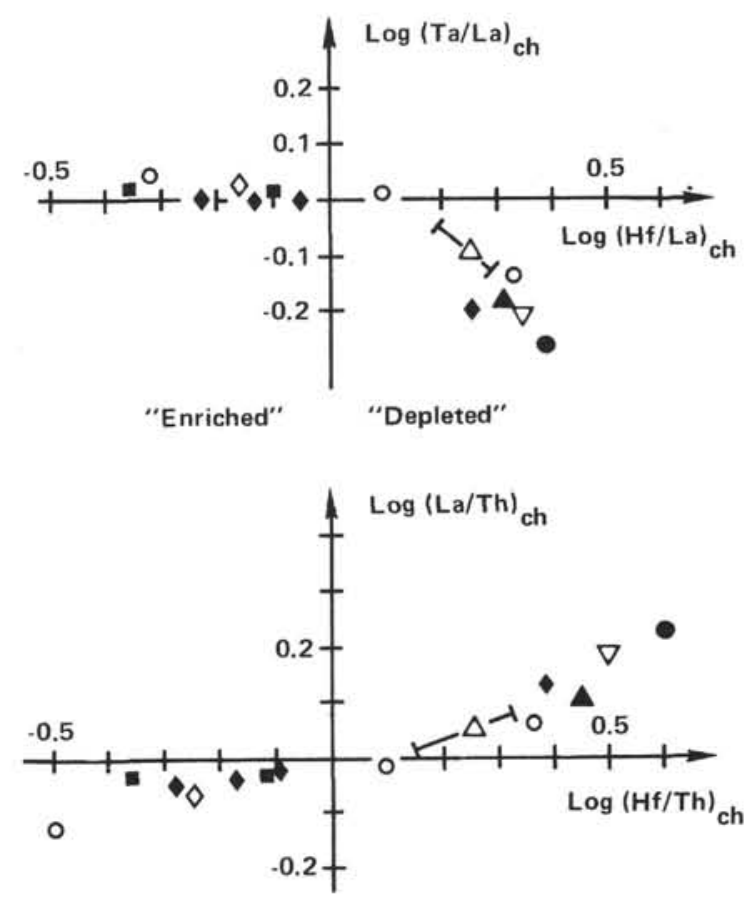

Figure 18. Leg 82 sites: logarithm of $\mathrm{Ta} / \mathrm{La}$ normalized ratio versus logarithm of $\mathrm{Hf} / \mathrm{La}$ normalized ratio and logarithm of $\mathrm{La} / \mathrm{Th}$ normalized ratio versus logarithm of $\mathrm{Hf} / \mathrm{Th}$ normalized ratio. Symbols as in Figure 14.

of 2 (Cambon et al., 1983). On the Costa Rica Rift (Hole 504B, Legs 69, and 70) [Etoubleau et al., 1983] and Leg 83 [Anderson, Honnorez, Becker, et al., in press]), almost all basalt samples recovered are extremely depleted in the most hygromagmaphile elements; the normalized $\mathrm{La} / \mathrm{Ta}$ ratio would be higher than 2 , which could indicate some fractionation of La-Ta $(\mathrm{Nb})$ for depleted samples, but the concentrations are so low that we have to be careful in such interpretations. However, in Hole 504B, two units show significant differences: one is less depleted than the majority of the samples and its normalized $\mathrm{La} / \mathrm{Ta}$ ratio is equal to 2 ; the other is slightly enriched and its normalized La/Ta ratio is equal to 1 (Etoubleau et al., 1983; Tual et al., 1983). Significant variations in $\mathrm{Nd}$ isotopic ratios are also observed (E. Tual, personal communication, 1983).

When the program of drilling ocean crust started in 1974, scientists attempted to sample different basalt units at one location and to relate them to one another through fractional crystallization processes. The results have shown that such cogenetic relationships are very difficult to find. This difficulty was interpreted in terms of magma mixing, whereby part of the basalt liquid is erupted on the seafloor and new primary liquid is injected in the magma chamber and is mixed with liquid that has already suffered some effects of fractional crystallization processes (Rhodes et al., 1979). This interpretation accounts for some of the complexity of the chemical compositions of lavas but cannot explain the different enriched and depleted extended Coryell-Masuda plots that have now been found in several locations. Some authors have also proposed the notion of permanent steady-state zoned magma chambers to account for some of the variation 
of the basalt samples that were collected in the FAMOUS area (Bryan and Moore, 1977; Bryan et al., 1979). Again, DSDP results since 1974 (based on mineralogic descriptions, major element compositions of lavas, and abundances of high partition coefficient elements and of hygromagmaphile elements) do not support this hypothesis. The absence of a negative correlation between high partition coefficient elements and hygromagmaphile elements can be interpreted by the proposition of Rhodes and others (1979); but, even if magma mixing is a likely process, it has a very strong limitation in terms of the duration of magma chambers. Such a process would imply high concentrations of all hygromagmaphile elements in the liquid phase; long-life steady-state magma chambers, even if zoned, would be factories for hygromagmaphile element enrichment (Cambon et al., 1983). More recently, it was proposed, for samples recovered between 22 and $25^{\circ} \mathrm{N}$ on the Mid-Atlantic Ridge, that simple low-pressure equilibrium crystallization during ascent in shallow vents or flow in seafloor lava tubes can account for a large part of the major and trace element variation within discrete data sets (Bryan et al., 1981).

The fact that we have now found, in the same hole, samples that present different extended Coryell-Masuda plots and crossing patterns-both on the Mid-Atlantic Ridge and on the East Pacific Rise-is a strong argument against the notion of long-term steady-state magma chambers. In addition, because the samples also have different isotopic ratios, the lavas were derived from different mantle sources. Extended Coryell-Masuda plots, $\mathrm{La} / \mathrm{Ta}$ (or $\mathrm{La} / \mathrm{Nb}$ ) ratios and isotopic ratios confirm the difficulty of finding cogenetic basalt units on the basis of major and high-partition-coefficient trace elements $(\mathrm{Cr}, \mathrm{Ni})$. These results constitute important constraints for any physical model of the construction of the ocean crust. Magma cycles (a concept initially proposed by Flower and Robinson [1979]), along with basalt liquids that can be produced from different mantle sources at a single location (via small individual magma chambers whose average lifetime and number could be a function of the spreading rate) and mixing and fractional crystallization in these chambers and vents, make up a complex process that accounts for the geochemical data in hand at the moment.

\section{Mineralogic Data: Lack of Compositional Variations Related to Mantle Heterogeneity}

A comparative microprobe study of some LREE-enriched and depleted basalts from Leg 82 sites has been conducted in order to test hypothetical mineralogic differences between the two groups. Six samples have been investigated: two of them enriched in hygromagmaphile elements (557-1-1, 57-58 cm; 561-1-1, 8-10 cm), the other four depleted $(561-1-1,123-124 \mathrm{~cm} ; 561-1-2,32-40$ $\mathrm{cm} ; 561-2-5,130-132 \mathrm{~cm}$; 562-4-1, 104-106 cm). The major element and transition element compositions of the four samples from Hole 561 are fairly constant. Sample 557-1-1, 57-58 cm is noticeably enriched in $\mathrm{TiO}_{2}$ and total iron and depleted in $\mathrm{Al}_{2} \mathrm{O}_{3}, \mathrm{MgO}$, and $\mathrm{CaO}$ compared to the other samples.
A Camebax Microbeam automated electron microprobe "Microsonde Ouest" in Brest has been used for mineral analyses. Most of the elements have been analyzed in the following conditions: $15 \mathrm{kV}, 10 \mathrm{nA}$, and counting time $=6 \mathrm{~s}$. Special attention was paid to the analysis of elements, the concentration levels of which are of some thousands of ppm $(\mathrm{Ni}, \mathrm{Mn}$, and $\mathrm{Ca}$ in olivines; $\mathrm{Ti}, \mathrm{Mn}$, and $\mathrm{Cr}$ in clinopyroxene; $\mathrm{Cr}$ and $\mathrm{V}$ in titanomagnetites; $\mathrm{Fe}, \mathrm{Mg}$, and $\mathrm{K}$, in plagioclases); they have been analyzed using $40 \mathrm{~s}$ counting time. Under these conditions, concentrations of 1000 and $5000 \mathrm{ppm}$ are thought to be determined with precisions of 10 and $3 \%$, respectively. Additionally, the plagioclases have been analyzed for $\mathrm{Sr}$, which has never been found in significant amounts.

Mean compositions of the major minerals from Leg 82 basalts are given in Tables 2 to 5 . The mineral compositions from LREE-enriched and LREE-depleted basalts, respectively, are systematically overlapping. The compositional variations encountered are like those classically described in ocean-floor tholeiites, and we have not found any indication of systematic differences in the physical or chemical conditions of crystallization of enriched and depleted basalts.

Olivines (Table 2) range in composition from $\mathrm{Fo}_{87}$ to $\mathrm{Fo}_{81}$, according to the $\mathrm{Fe} / \mathrm{Fe}+\mathrm{Mg}$ ratios of their host lavas. A significant iron-enrichment is found from the cores of phenocrysts to their rims and to the groundmass. Their Ni contents show a positive correlation with $\mathrm{Mg}$; their calcium contents, which are dependent on silica activity and total pressure (Stormer, 1973), are identical for enriched and depleted samples.

Calcic clinopyroxenes (Table 3), the compositions of which are considered to be strongly dependent on physical and chemical conditions of crystallization (Cameron and Papike, 1981; Leterrier et al., 1982) do not show systematic differences between the two groups. Their position in the $\mathrm{Ca}-\mathrm{Mg}-(\mathrm{Fe}+\mathrm{Mn})$ diagram is almost identical for pyroxenes from enriched and depleted tholeiites, and the groundmass pyroxenes show the iron-enrichment and $\mathrm{Ca}$-depletion and $\mathrm{Mg}$-depletion so often described in ocean basalts. The concentrations of $\mathrm{Ca}$, $\mathrm{Ti}, \mathrm{Al}$, and $\mathrm{Na}$ in clinopyroxenes, which are thought to increase with the alkalinity of host basalts (Schweitzer et al., 1979), do not form independent fields that can be related to each group.

Groundmass Titanomagnetites (Table 4) from enriched and depleted samples show identical composition ranges, even for minor elements $(\mathrm{Si}, \mathrm{Cr}, \mathrm{Mn}, \mathrm{Ca}, \mathrm{V})$.

Plagioclases (Table 5) show wide variations in composition, from $\mathrm{An}_{92}$ to $\mathrm{An}_{50}$ for the cores of the phenocrysts and $A_{85}$ to $A_{15}$ for groundmass plagioclases. These variations are primarily related to the more or less evolved character of their host magma: among the studied basalts, Sample 557-1-1, 57-58 cm contains plagioclase phenocrysts and groundmass crystals clearly more sodic than those from the other Leg 82 basalts; additionally, their analyses show significant amounts of $\mathrm{K}_{2} \mathrm{O}$, increasing from the cores of the phenocrysts to their rims and to the groundmass crystals. Enriched and depleted 
Table 2. Mean compositions of olivines.

\begin{tabular}{|c|c|c|c|c|c|c|c|c|}
\hline \multirow{3}{*}{$\begin{array}{l}\text { Sample } \\
\text { Position }\end{array}$} & \multicolumn{4}{|c|}{$561-1-1,8-10$ (LREE enriched) } & \multicolumn{4}{|c|}{$561-2-5,120-132$ (LREE depleted) } \\
\hline & \multicolumn{2}{|c|}{ Cores (5) } & \multicolumn{2}{|c|}{ Groundmass (5) } & \multicolumn{2}{|c|}{ Cores (5) } & \multicolumn{2}{|c|}{ Groundmass (5) } \\
\hline & $\mathrm{m}$ & $\mathrm{S}$ & m & $\mathrm{S}$ & m & $\mathrm{S}$ & $\mathrm{m}$ & $\mathrm{S}$ \\
\hline $\mathrm{SiO}_{2}$ & 39.53 & 0.53 & 39.58 & 0.32 & 38.81 & 0.54 & 38.78 & 0.37 \\
\hline $\mathrm{FeO}^{*}$ & 12.37 & 0.52 & 13.59 & 0.82 & 16.05 & 0.26 & 16.95 & 0.35 \\
\hline $\mathrm{MnO}$ & 0.19 & 0.05 & 0.23 & 0.05 & 0.26 & 0.01 & 0.25 & 0.03 \\
\hline $\mathrm{MgO}$ & 47.88 & 0.89 & 46.64 & 0.76 & 46.76 & 0.48 & 46.14 & 0.62 \\
\hline $\mathrm{NiO}$ & 0.24 & 0.04 & 0.19 & 0.03 & 0.15 & 0.01 & 0.15 & 0.01 \\
\hline
\end{tabular}

Note: $\mathrm{LREE}=$ light rare earth elements; $\mathrm{m}=$ mean value; $\mathrm{S}=$ standard deviation . The number of analyses is indicated in parentheses. $\mathrm{FeO}^{*}=$ total iron as $\mathrm{FeO}$. Sample numbers are expressed as Hole-Core-Section (interval in $\mathrm{cm}$ ).

Table 3. Mean compositions of clinopyroxenes.

\begin{tabular}{|c|c|c|c|c|c|c|c|c|c|c|c|c|}
\hline \multirow{4}{*}{$\begin{array}{l}\text { LREE } \\
\text { Sample } \\
\text { Position }\end{array}$} & \multicolumn{6}{|c|}{ LREE enriched } & \multicolumn{6}{|c|}{ LREE depleted } \\
\hline & \multicolumn{4}{|c|}{$557-1-1,57-58$} & \multirow{2}{*}{\multicolumn{2}{|c|}{$\frac{561-1-1,8-10}{\text { Groundmass (6) }}$}} & \multirow{2}{*}{\multicolumn{2}{|c|}{$\frac{561-1-1,123-124}{\text { Groundmass (6) }}$}} & \multirow{2}{*}{\multicolumn{2}{|c|}{$\frac{561-1-1,32-40}{\text { Groundmass (6) }}$}} & \multirow{2}{*}{\multicolumn{2}{|c|}{$\frac{561-2-5,130-132}{\text { Groundmass (6) }}$}} \\
\hline & \multicolumn{2}{|c|}{ Cores (4) } & \multicolumn{2}{|c|}{ Groundmass (6) } & & & & & & & & \\
\hline & $\mathrm{m}$ & $\mathrm{S}$ & $\mathrm{m}$ & $\mathrm{S}$ & $\mathrm{m}$ & $\mathrm{s}$ & $\mathrm{m}$ & $\mathrm{s}$ & $\mathrm{m}$ & $\mathrm{S}$ & $\mathrm{m}$ & $\mathrm{S}$ \\
\hline $\mathrm{SiO}_{2}$ & 50.34 & 0.31 & 48.51 & 0.85 & 47.80 & 0.94 & 49.46 & 1.87 & 48.94 & 1.48 & 49.20 & 0.77 \\
\hline $\mathrm{TiO}_{2}$ & 1.23 & 0.21 & 0.80 & 0.28 & 1.55 & 0.19 & 1.20 & 0.50 & 1.23 & 0.36 & 1.13 & 0.25 \\
\hline $\mathrm{Al}_{2} \mathrm{O}_{3}$ & 2.40 & 0.38 & 1.05 & 0.33 & 5.07 & 1.32 & 4.64 & 1.23 & 5.57 & 0.75 & 4.60 & 0.67 \\
\hline $\mathrm{Cr}_{2} \mathrm{Q}_{3}$ & 0.00 & 0.00 & 0.00 & 0.00 & 0.14 & 0.11 & 0.19 & 0.17 & 0.22 & 0.15 & 0.16 & 0.10 \\
\hline $\mathrm{FeO}^{\circ}$ & 12.56 & 1.88 & 26.57 & 3.14 & 10.81 & 2.03 & 11.99 & 4.67 & 10.21 & 3.35 & 9.15 & 0.76 \\
\hline $\mathrm{MnO}$ & 0.33 & 0.10 & 0.69 & 0.13 & 0.23 & 0.10 & 0.27 & 0.10 & 0.25 & 0.08 & 0.22 & 0.03 \\
\hline $\mathrm{MgO}$ & 15.51 & 0.69 & 6.42 & 3.00 & 14.19 & 0.79 & 17.61 & 4.14 & 17.66 & 2.58 & 19.08 & 0.90 \\
\hline $\mathrm{CaO}$ & 18.15 & 1.11 & 16.38 & 2.40 & 19.76 & 1.13 & 15.02 & 1.72 & 16.36 & 1.62 & 17.25 & 0.83 \\
\hline $\mathrm{Na}_{2} \mathrm{O}$ & 0.27 & 0.10 & 0.35 & 0.10 & 0.41 & 0.05 & 0.30 & 0.09 & 0.33 & 0.10 & 0.28 & 0.12 \\
\hline
\end{tabular}

Note: Conventions as in Table 2.

Table 4. Representative analyses of groundmass titanomagnetites.

\begin{tabular}{|c|c|c|c|c|c|c|c|}
\hline \multirow{3}{*}{$\begin{array}{l}\text { Sample } \\
\mathrm{SiO}_{2}\end{array}$} & \multicolumn{4}{|c|}{ LREE enriched } & \multicolumn{3}{|c|}{ LREE depleted } \\
\hline & \multicolumn{2}{|c|}{$557-1-1,57-58$} & \multicolumn{2}{|c|}{$561-1-1,8-10$} & \multicolumn{2}{|c|}{$561-2-5,130-132$} & \multirow{2}{*}{$\frac{562-4-1,104-106}{0.14}$} \\
\hline & 0.13 & 0.18 & 0.15 & 0.30 & 0.18 & 0.26 & \\
\hline $\mathrm{TiO}_{2}$ & 21.20 & 20.35 & 14.83 & 14.81 & 17.20 & 16.85 & 22.77 \\
\hline $\mathrm{Al}_{2} \mathrm{O}_{3}$ & 0.60 & 0.65 & 3.14 & 3.29 & 2.36 & 2.17 & 2.07 \\
\hline $\mathrm{Cr}_{2} \mathrm{O}_{3}$ & 0.00 & 0.00 & 0.05 & 0.05 & 0.00 & 0.01 & 0.00 \\
\hline $\mathrm{Fe}_{2} \mathrm{O}_{3}$ & 27.51 & 28.44 & 37.12 & 35.86 & 32.49 & 33.06 & 22.84 \\
\hline $\mathrm{FeO}$ & 50.35 & 49.12 & 42.77 & 42.70 & 45.04 & 44.71 & 50.87 \\
\hline $\mathrm{MnO}$ & 0.51 & 0.53 & 0.41 & 0.49 & 0.36 & 0.32 & 0.63 \\
\hline $\mathrm{MgO}$ & 0.03 & 0.11 & 1.35 & 1.07 & 1.02 & 0.95 & 0.65 \\
\hline $\mathrm{CaO}$ & 0.01 & 0.28 & 0.20 & 0.33 & 0.20 & 0.24 & 0.09 \\
\hline $\mathrm{V}_{2} \mathrm{O}_{5}$ & 0.00 & 0.00 & 0.60 & 0.67 & 0.64 & 0.74 & 0.56 \\
\hline Total & 100.34 & 99.66 & 100.62 & 99.57 & 99.49 & 99.31 & 100.62 \\
\hline
\end{tabular}

Note: Iron contents distributed as $\mathrm{FeO}$ and $\mathrm{Fe}_{2} \mathrm{O}_{3}$ according to $\mathrm{R}_{3} \mathrm{O}_{4}$ stoichiometry. Other conventions as in Table 2.

Table 5. Mean compositions of plagioclases.

\begin{tabular}{|c|c|c|c|c|c|c|c|c|c|c|c|c|c|c|c|c|}
\hline \multirow{4}{*}{$\begin{array}{l}\text { Sample } \\
\text { Position }\end{array}$} & \multicolumn{8}{|c|}{ LREE enriched } & \multicolumn{8}{|c|}{ LREE depleted } \\
\hline & \multicolumn{4}{|c|}{$557-1-1,57-58$} & \multicolumn{4}{|c|}{$561-1-1,8-10$} & \multicolumn{4}{|c|}{$561-1-1,123-124$} & \multicolumn{4}{|c|}{$562-4-1,104-106$} \\
\hline & \multicolumn{2}{|c|}{ Cores (6) } & \multicolumn{2}{|c|}{ Groundmass (5) } & \multicolumn{2}{|c|}{ Cores (5) } & \multicolumn{2}{|c|}{ Groundmass (5) } & \multicolumn{2}{|c|}{ Cores (6) } & \multicolumn{2}{|c|}{ Groundmass (5) } & \multicolumn{2}{|c|}{ Cores (6) } & \multicolumn{2}{|c|}{ Groundmass (6) } \\
\hline & $\mathrm{m}$ & S & m & $\mathrm{S}$ & $\mathrm{m}$ & S & m & S & m & $\mathrm{S}$ & m & $\mathrm{S}$ & $\mathrm{m}$ & S & $\mathrm{m}$ & $\mathrm{S}$ \\
\hline $\mathrm{SiO}_{2}$ & 54.37 & 1.09 & 60.56 & 3.51 & 52.27 & 0.65 & 52 & 0. & 49.80 & 1.54 & 51.28 & 0.75 & 45.67 & 0.93 & 53.12 & 1.25 \\
\hline $\mathrm{Al}_{2} \mathrm{O}_{3}$ & 29.10 & 0.38 & 24.99 & 2.40 & 30.21 & 0.84 & 30.57 & 0.53 & 32.67 & 1.00 & 31.67 & 0.85 & 35.11 & 0.63 & 29.28 & 1.06 \\
\hline $\mathrm{Fe}_{2} \mathrm{O}_{3}$ & 0.61 & 0.12 & 0.47 & 0.23 & 0.87 & 0.26 & 0.81 & 0.17 & 0.46 & 0.16 & 0.65 & 0.16 & 0.32 & 0.08 & 0.82 & 0.24 \\
\hline $\mathrm{MgO}$ & 0.13 & 0.02 & 0.03 & 0.03 & 0.46 & 0.06 & 0.40 & 0.08 & 0.29 & 0.03 & 0.31 & 0.07 & 0.25 & 0.05 & 0.29 & 0.10 \\
\hline $\mathrm{CaO}$ & 11.21 & 0.70 & 6.13 & 2.70 & 13.86 & 0.52 & 13.96 & 0.51 & 15.47 & 1.05 & 14.37 & 0.61 & 18.06 & 0.58 & 12.13 & 1.00 \\
\hline $\mathrm{Na}_{2} \mathrm{O}$ & 5.48 & 0.32 & 8.25 & 1.35 & 3.86 & 0.46 & 3.85 & 0.42 & 2.88 & 0.57 & 3.48 & 0.49 & 1.46 & 0.43 & 4.93 & 0.80 \\
\hline $\mathrm{K}_{2} \mathrm{O}$ & 0.19 & 0.03 & 0.51 & 0.22 & 0.06 & 0.02 & 0.05 & 0.02 & 0.00 & 0.00 & 0.01 & 0.01 & 0.00 & 0.00 & 0.04 & 0.01 \\
\hline
\end{tabular}

Note: $\mathrm{Fe}_{2} \mathrm{O}_{3}{ }^{*}$ : total iron as $\mathrm{Fe}_{2} \mathrm{O}_{3}$. Other conventions as in Table 2. 
basalts of fairly equivalent major element chemistry (e.g., Samples 561-1-1, 8-10 cm and 561-1-1, 123-124 $\mathrm{cm})$ contain similar plagioclases, the compositions of which do not differ in any way from one another, even for $\mathrm{Mg}$ minor elements $(\mathrm{Fe}, \mathrm{Mg}, \mathrm{K})$. The occurrence of significant amounts of $\mathrm{Mg}$ in plagioclases from ocean tholeiites (Hawkins, 1977) is confirmed by our data.

\section{$\mathrm{Pb}, \mathrm{Sr}, \mathrm{Nd}$ Isotopic Ratios and Hygromagmaphile Element Ratios: New Constraints for Mantle Heterogeneities and Partial Melting Processes}

Sites other than 558 and 561 drilled during Leg 82 are homogeneous in enrichment or depletion in hygromagmaphile elements. The related isotopic ratios (Jenner et al.; Dupré et al.; Rideout et al., all this volume) also show homogeneous data. Nevertheless, regular trends are not observed between isotopic ratios and hygromagmaphile element ratios. For example, Site 556 is the most depleted in LREEs and $\mathrm{Th}, \mathrm{Ta}$, and $\mathrm{Nb}$, but the corresponding $\mathrm{Pb}$ isotopic ratios are by far not the lowest among the sites drilled during Leg 82, as shown in Figure 19 (Dupré et al., this volume). This figure shows that high isotopic ratios correspond to enriched material, but both low and somewhat high $\mathrm{Pb}$ isotopic ratios correspond to depleted material. In other words, the trends that would associate radiogenic ratios to hygromagmaphile ratios in a continuous regular variation, as proposed by Allègre and others (1980) and Dupré and Allègre (1980), are more complicated.

Different $\mathrm{Pb}, \mathrm{Sr}$, and $\mathrm{Nd}$ isotopic ratios in basalts indicate different histories of the mantle sources, different events that induced fractionation of hygromagmaphile elements, and different amounts of time are necessary to produce different isotopic ratios. The ratios of hygromagmaphile elements in basalts depend only on fractionation during these events but do not depend on time. Because we do not know how to evaluate the extent of the last melting event, it is theoretically not possible to

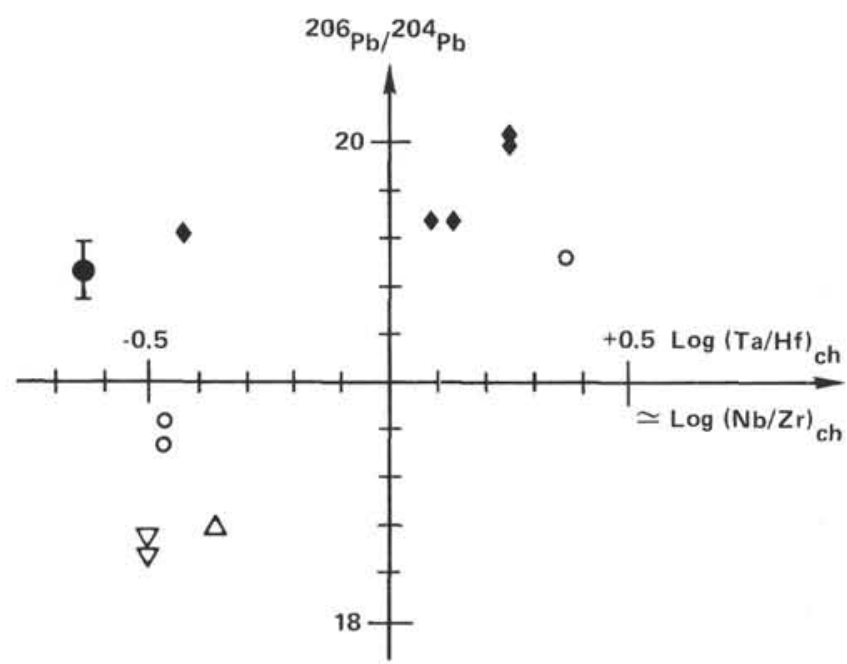

Figure 19. Leg 82 sites: ${ }^{206} \mathrm{~Pb} /{ }^{204} \mathrm{~Pb}$ versus logarithm of $\mathrm{Ta} / \mathrm{Hf}$ normalized to chondrites. $\mathrm{Ta} / \mathrm{Hf}$ is equivalent to $\mathrm{Nb} / \mathrm{Zr}$. Subscript ch indicates normalized to chondrites. From Dupré et al., this volume. Symbols as in Figure 14. distinguish between a basalt that was the product of a large degree of melting of a primordial mantle source and a basalt that would be the result of a smaller degree of melting of an already depleted mantle source. Another way of presenting this proposition is to consider a basalt as the result of a multistage melting process of primordial mantle without any reference to the time when these stages or events occurred; without isotopic data it is not possible to know when some of these stages occurred. If most of the episodes of melting occurred in a recent period, we can consider that the mantle is close to primordial in respect to isotopes. Basalt liquids will have high radiogenic $\mathrm{Sr}, \mathrm{Pb}$, and $\mathrm{Nd}$ contents, whatever the extent of melting and the number of melting stages. According to the extent and the methods of melting, theoretically either enriched or depleted liquids can be produced. If some episodes occurred a long time ago, the present basalt liquids necessarily derived from a depleted mantle source with low $\mathrm{Pb}$ and $\mathrm{Sr}$ and high $\mathrm{Nd}$ isotopic ratios; correlatively, because they were formed from a depleted source, basalt liquids tend to be depleted (Fig. 9). Even if mixing of mantle plume material with depleted mantle material involves differing extent or methods of melting, it is not possible to have samples with high $\mathrm{Ta} / \mathrm{Hf}$ and low ${ }^{206} \mathrm{~Pb} /{ }^{204} \mathrm{~Pb}$. According to this interpretation, the main result would be that starting from a plumelike mantle material, it is possible to have extents and methods of melting that can produce LREEdepleted basalts. A quantitative approach would need to account for recycling part of the ocean crust and sediments through subduction zones (Cohen and O'Nions, 1982 ) and other processes that would tend to erase heterogeneities (by diffusion and advection, as discussed by Allègre and others (1980). The new information from Leg 82 is that basalt samples with high $\mathrm{Pb}$ isotopic ratios can have low hygromagmaphile ratios (such as $\mathrm{La}$ / $\mathrm{Sm}$ or $\mathrm{Ta} / \mathrm{Hf}$ ).

\section{Regional Mantle Heterogeneity}

So far, we have been discussing the data in terms of comparative geochemistry and processes; we have come to the conclusion that different mantle sources can contribute in forming layer two in a restricted area. What about the regional variation versus time and along isochrons? Is there any clear relationship with zero-age variations along the ridge axis from the Azores Triple Junction to south of Hayes Fracture Zone?

First, almost the entire range of possible variation of $\mathrm{La} / \mathrm{Sm}$ ratio occurs in a single hole, which makes it somewhat difficult to produce a regional picture unless data are available for many sites. In this respect, drilling a hole down to some tens of meters is about the equivalent of a dredge haul at the axis. Producing a regional picture is then difficult both because of large variations that are observed within a single hole and because of the limited number of drilled sites when compared to the number of dredge sites along the axis.

South of the Hayes Fracture Zone, the samples recovered at three sites (562 on Anomaly 5, 563 and 564 on Anomaly 13) are depleted MORB with low $\mathrm{Pb}$ isotopic ratios and high Nd isotopic ratios. Nevertheless, 
we note that normalized $\mathrm{La} / \mathrm{Ta}$ ratios do not reach the value 2 as observed at several locations for zero-age samples. In addition, a range of variation of this ratio and $\mathrm{Ta} / \mathrm{Hf}, \mathrm{Nb} / \mathrm{Zr}$, or $\mathrm{La} / \mathrm{Sm}$ ratios is observed at Site 564 . We thus conclude that south of the Hayes Fracture Zone the depleted character of the basalts is a general feature; but, the variations observed in the concentrations and ratios of hygromagmaphile elements preclude "typical depleted MORB's" being identical or being generated from identical mantle sources through identical extent of melting.

North of the Hayes Fracture Zone, the picture is more complicated. When compared to sites situated south of the Hayes Fracture Zone, the only common characteristic of the northern sites is a tendency to have higher $\mathrm{Pb}$ and lower $\mathrm{Nd}$ isotopic ratios and to be enriched in hygromagmaphile elements. Comparing the trace element and isotopic ratios of the northern sites, we cannot find relationships either away from the axis of the ridge or along isochrons that could be accounted for by the regular influence of a mantle plume at the present Azores Triple Junction. First, the interpretation needs to account for the reconstruction of the North Atlantic at the time of Anomalies 5 and 13, the possible variation of the Azores hot spot during the last $35 \mathrm{Ma}$ (Cande et al., 1983), and the possible influence of other hot spots, such as defined by the New England Seamount Chain. Second, even with a hypothesis of a fixed hot spot (or a hot spot fixed for a period of time), we have to consider that the effect of a plume away from the hot spot is discontinuous and involves separated parts of the plume or blobs; if we add that mixing with a normal MORB source is far from ideal, we can explain, at least in part, the heterogeneity of the results. Third, a better understanding of this region and related mantle processes would need better documentation of the hygromagmaphile data and isotopes of this area. The density of holes drilled during Leg 82 (off the ridge axis) compared to the density of dredge hauls (at the axis) between the Hayes Fracture Zone and the Azores Triple Junction is obviously very low. We know that different enrichment factors can be observed within a single dredge and also that the deepest sample investigated in Hole 413 (Leg 49; Wood, Varet, et al., 1979), from close to the ridge axis in the FAMOUS area, has a depleted REE pattern (Wood, Tarney et al., 1979), which is opposite to all other samples of this hole; unfortunately, no isotope data are available.

\section{CONCLUSIONS}

Geochemistry of hygromagmaphile elements. We have been trying to incorporate both the REEs and other hygromagmaphile elements in a comprehensive picture, the so-called extended Coryell-Masuda plot, which is both a classification of the elements versus their bulk hygromagmaphile character and a tool for the characterization and the interpretation of the genesis of basalts. We have shown that this concept can be used practically; we were able on board to characterize the different groups of basalts recovered by using only $\mathrm{Nb}, \mathrm{Zr}, \mathrm{Ti}, \mathrm{Y}$, and $\mathrm{V}$ to deduce exactly the same information that can be obtained from the REEs themselves.
The nonfractionation of $\mathrm{La}$ and $\mathrm{(Nb}, \mathrm{Ta})$ over a large range of variation in concentration of these elements (from about 10 to 90 for normalized concentrations) is confirmed. The variation of the normalized $\mathrm{La} /(\mathrm{Ta}, \mathrm{Nb})$ ratio for normalized concentrations lower than 10 (e.g., Hole 564) is interpreted either as the effect of mixing of different mantle sources or of fractionation of these elements in depleted mantle sources.

"Crossing patterns" in a single drill hole. Crossing patterns of extended Coryell-Masuda plots have been found in the same hole; these crossing patterns cover almost the entire spectrum of extended Coryell-Masuda plots; At site 561, they are associated with different isotopic ratios. This obviously demonstrates the contribution of at least two mantle sources at the same location in building the ocean crust. In addition, this result has implications for physical models that can account for the construction of the ocean crust; it favors a model of small, discrete, short-time magma chambers rather than a permanent steady-state magma chamber at the ridge axis. A mineralogic study did not find any indication of systematic differences in the physical or chemical conditions of crystallization for enriched and depleted basalts.

Hygromagmaphile ratios and isotopic ratios. Leg 82 provides new data on hygromagmaphile ratios and isotopic ratios; in particular, it shows that a sample can be characterized by high $\mathrm{Pb}$ isotopic ratios with a depleted hygromagmaphile element signature. This result indicates that a depleted basalt can be produced from plumelike mantle material in a short period of time, in contrast to other basalts that have a depleted character and low $\mathrm{Pb}$ isotopic ratios that by definition, need fractionations that occurred a long time ago. This casts new light on mantle source characteristics and partial melting processes.

Local versus regional mantle heterogeneity. We have already reported that Leg 82 has documented local mantle heterogeneity (crossing patterns of extended CoryellMasuda plots and different isotopic ratios). South of the Hayes Fracture Zone, all sites yielded basalts with a depleted character and low $\mathrm{Pb}$ and $\mathrm{Sr}$, high $\mathrm{Nd}$ isotopic ratios; but all sites, as well as zero-age sites, are not identical in these properties. North of the Hayes Fracture $\mathrm{Zone}, \mathrm{Pb}$ isotopic ratios tend to be higher than to the south, but a range of values is observed; at the same time, both enriched and depleted material has been recovered north of the Hayes Fracture Zone. In this respect, the influence of "plumelike" mantle sources is observed. But, because of the complexity that has been reported (crossing patterns of extended Coryell-Masuda plots, more complex relationships between hygromagmaphile elements and isotopic ratio), it is not possible to deduce a clear picture along flow lines or along isochrons that could be related to a simple fixed hot spot at the Azores Triple Junction.

\section{ACKNOWLEDGMENTS}

We thank the crew, the drillers, and the scientific party of Leg 82 of the Glomar Challenger; all of them helped to make available this sample set from the Azores Triple Junction. We thank B. Weaver and $\mathrm{H}$. McSween for comments and corrections. We are grateful to C. Ollivier for typing the manuscript. 


\section{REFERENCES}

Allègre, C. J., Brévart, O., Dupré, B., and Minster, J. F., 1980. Isotopic and chemical effects produced in a continuously differentiating earth mantle. Phil. Trans. R. Soc. London, A297:447-477.

Aumento, F., Melson, W. G., et al., 1977. Init. Repts. DSDP, 37: Washington (U.S. Govt. Printing Office).

Anderson, R. N., Honnorez, J., Becker, K., et al., in press. Init. Repts. DSDP, 83: Washington (U.S. Govt. Printing Office).

Bertrand, H., Dostal, J., and Dupuy, C., 1982. Geochemistry of early mesozoic tholerites from Morocco. Earth Planet. Sci. Lett., 58: 225-239.

Bougault, H., 1977. First transition series elements: fractional crystallization and partial melting. In Aumento, F., Melson, W. G., et al., Init. Repts. DSDP, 37: Washington (U.S. Govt. Printing Office), 539-546.

1980. Contribution des éléments de transition à la compréhension de la génèse des basaltes océaniques. Analyse des éléments traces dans les roches par spectrométrie de fluorescence $\mathrm{X}$ [Thèse]. Université Paris VII, Paris.

Bougault, H., and Cambon, P., 1973. Dispersive X-ray fluorescence analysis on board oceanographic vessels. Mar. Geol., 15:37-41.

Bougault, H., and Cambon, P., Corre, O., Joron, J. L., and Treuil, M., 1979. Evidence for variability of magmatic processes and upper mantle heterogeneity in the axial region of the Mid-Atlantic Ridge near $22^{\circ}$ and $36^{\circ} \mathrm{N}$. Tectonophysics, 55:11-34.

Bougault, H., Cambon, P., Joron, J. L., and Treuil, M., 1978. Trace elements: fractional crystallization and partial melting processes, heterogeneity of the upper mantle material. In Dmitriev, L., Heirtzler, J., et al., Init. Repts. DSDP, 46: Washington (U.S. Govt. Printing Office), 247-251.

Bougault, H., Joron, J. L., and Treuil, M., 1979. Alteration, fractional crystallization, partial melting, mantle properties from trace elements in basalts recovered in the North Atlantic. In Talwani, M., Harrison, C. G., and Hayes, D. E. (Eds.), Deep Drilling Results in the Atlantic Ocean: Ocean Crust: Washington (Am. Geophys. Union), Maurice Ewing Series, 2:352-368.

Bougault, H., and Treuil, M., 1980. Mid-Atlantic Ridge: zero age geochemical variations between Azores and $22^{\circ} \mathrm{N}$. Nature, 286(5770): 209-212.

Bougault, H., Treuil, M., and Joron, J. L., 1978. Trace elements in basalts from $23^{\circ} \mathrm{N}$ and $36^{\circ} \mathrm{N}$ in the Atlantic Ocean: fractional crystallization, partial melting, and heterogeneity of the upper mantle. In Melson, W. G., Rabinowitz, P. D., et al., Init. Repts. $D S D P, 45$ : Washington (U.S. Govt. Printing Office), 493-506.

Briqueu, L., Bougault, H., and Joron, J. L., in press. Several geochemical characteristics common to magmatisms associated with convergence zones: the $\mathrm{Ta}-\mathrm{Nb}$ anomaly; petrogenetic implications. Earth Planet. Sci. Lett.

Bryan, W. B., and Moore, J. G., 1977. Compositional variations of young basalts in the Mid-Atlantic Ridge rift valley near lat. $36^{\circ} 49^{\prime}$ N. Geol. Soc. Am. Bull., 88:556-570.

Bryan, W. B., Thompson, G., and Ludden, J. N., 1981. Compositional variation in Normal MORB from $22^{\circ}-25^{\circ} \mathrm{N}$ Mid-Atlantic Ridge and Kane Fracture Zone. J. Geophys. Res., 86(B12): $11815-11836$.

Bryan, W. B., Thompson, G., and Michael, P. J., 1979. Compositional variation in a steady state zoned magma chamber: Mid-Atlantic Ridge at $36^{\circ} 50^{\prime} \mathrm{N}$. Tectonophysics, 55:63-85.

Cambon, P., Joron, J. L., Bougault, H., and Treuil, M., 1980. Emperor Seamounts: trace elements in transitional tholeiites, alkali basalts and Hawaiites-mantle homogeneity or heterogeneity and magmatic processes. In Jackson, E. D., Koizumi, I., et al., Init. Repts. DSDP, 55: Washington (U.S. Govt. Printing Office), 585-597.

Cambon, P., Bougault, H., Joron, J. L., and Treuil, M., 1983. Basalts from the East Pacific Rise: an example of typical oceanic crust depleted in hygromagmaphile elements. In Lewis, B. T. R., Robinson, P., et al., Init. Repts. DSDP, 65: Washington (U.S. Govt. Printing Office), 623-634.
Cameron, M., and Papike, J. J., 1981. Structural and chemical variations in clinopyroxenes. Am. Mineral., 66:1-50.

Cande, S. C., Bougault, H., Hill, L., Morgan, W. J., and Schouten, H., 1983. North Atlantic hot spot tracks and the pattern of enriched or depleted basalts in Leg 82 drill holes. EOS, Trans. Am. Geophys. Union, 64(18):345. (Abstract)

Cohen, R. S., and O'Nions, R. K., 1982. Identification of recycled continental material in the mantle from $\mathrm{Sr}, \mathrm{Nd}$ and $\mathrm{Pb}$ isotope investigations. Earth Planet. Sci. Lett., 61:73-84.

Coryell, C. D., Chase, J. W., and Winchester, J. W., 1963. A procedure for geochemical interpretation of terrestrial rare earth abundance patterns. J. Geophys. Res., 68:559.

Duncan, R. A., and Green, D. H., 1980. Role of multi-stage melting in the formation of the ocean crust. Geology, 8:22-26.

Dupré, B., and Allègre, C. J., 1980. Pb-Sr-Nd isotopic correlation and the chemistry of the North Atlantic Mantle. Nature, 286(5768): 17-22.

Dupuy, C., Dostal, J., Marcelot, G., Bougault, H., Joron, J. L., and Treuil, M., 1982. Geochemistry of basalts from central and southern New Hebrides arc: implication for their source rock composition. Earth Planet. Sci. Lett., 60:207-225.

El Azzouzi, M., Bougault, H., Maury, R., and Villemant, B., 1982. Application du diagramme de Coryell-Masuda "élargi" à l'étude du fractionnement du titane et du vanadium dans la série alcaline de la chaîne des Puys. C. R. Acad. Sci., Ser. II, 295:1117-1120.

Engel, A. E. J., Engel, C. G., and Havens, R. G., 1965. Chemical characteristics of oceanic basalts and the upper mantle. Geol. Soc. Am. Bull., 76:719-734.

Erlank, A. J., and Kable, E. J. D., 1976. The significance of incompatible elements in Mid-Atlantic Ridge basalts from $45^{\circ} \mathrm{N}$ with particular reference to $\mathrm{Zr} / \mathrm{Nb}$. Contrib. Mineral. Petrol., 54:281.

Etoubleau, J., Corre, O., Joron, J. L., Bougault, H., and Treuil, M., 1983. Costa Rica Rift: variable depleted basalts in the same hole. In Cann, J. R., Langseth, M. G., Honnorez, J., Von Herzen, R. P., White, S. M., et al., Init. Repts. DSDP, 69: Washington (U.S. Govt. Printing Office), 765-773.

Flower, M. F. J., and Robinson, P. T., 1979. Evolution of the "FAMOUS" ocean ridge segment: evidence from submarine and deep sea drilling investigations. In Talwani, M., Harrison, C. G., and Hayes, D. E. (Eds.), Deep Drilling Results in the Atlantic Ocean: Ocean Crust: Washington (Am. Geophys. Union), Maurice Ewing Series, 2:314-330.

Frey, F. A., Bryan, W. B., and Thompson, G., 1974. Atlantic Ocean floor: geochemistry and petrology basalts from Legs 2 and 3 of the Deep Sea Drilling Project. J. Geophys. Res., 79:5507-5527.

Frey, F. A., and Haskin, L. A., 1964. Rare earths in oceanic basalts. J. Geophys. Res. 69:775-780.

Frey, F. A., Haskin, M. A., Poetz, J. A., and Haskin, L. A., 1968. Rare-earth abundances in some basic rocks. J. Geophys. Res., 73: 6085-6098.

Gast, P. W., 1968. Trace element fractionation and the origin of tholeiitic and alkaline magma types. Geochim. Cosmochim. Acta, 32: 1057-1086.

Gast, P. W., Tilton, G. R., and Hedge, C., 1964. Isotopic composition of lead and strontium from Ascension and Gough Islands Science, 145:1181.

Hart, S. R., Schilling, J. G., and Poweil, J. L., 1973. Basalts from Iceland and along the Reykjanes Ridge: $\mathrm{Sr}$ isotope geochemistry. $\mathrm{Na}$ ture, 246:104.

Hawkins, S. J. W., 1977. Petrologic and geochemical characteristics of marginal basin basalts. In Talwani, M., and Pitman, W., III (Eds.), Island Arcs, Deep-Sea Trenches and Back-Arc Basins: Washington (Am. Geophys. Union), Maurice Ewing Ser., 1:355-366.

Jaffrezic, H., Joron, J. L., and Treuil, M., 1977. Trace element determination in rock powder. A study of the precision for a given analytical procedure: instrumental epithermal neutron activation. J. Radioanal. Chem., 39:185-188.

Joron, J. L., Bollinger, C., Quisefit, J. P., Bougault, H., and Treuil, M., 1979. Trace elements in Cretaceous basalts at $25^{\circ} \mathrm{N}$ in the Atlantic Ocean: alteration, mantle compositions, and magmatic pro- 
cesses. In Donnelly, T., Francheteau, J., Bryan, W., Robinson, P., Flower, M., Salisbury, M., et al., Init. Repts. DSDP, 51,52,53, Pt. 2: Washington (U.S. Govt. Printing Office), 1087-1098.

Langmuir, C. H., Bender, J. F., Bence, A. E., Hanson, G. N., and Taylor, S. R., 1977. Petrogenesis of basalts from the "FAMOUS" area: Mid-Atlantic Ridge. Earth Planet. Sci. Lett., 36:133-156.

Le Douaran, S., and Francheteau, J., 1981. Axial depth anomalies from 10 to $50^{\circ}$ north along the Mid-Atlantic Ridge: correlation with other mantle properties. Earth Planet. Sci. Lett., 54:29-47.

Leterrier, J., Maury, R., Thonon, P., Girard, D., and Marchal, M., 1982. Clinopyroxene composition as a method of identification of the magmatic affinities of paleo-volcanic series. Earth Planet. Sci. Lett., 59:139-154.

Machado, N., Ludden, J. N., Brooks, C., and Thompson, G., 1982. Fine scale isotopic heterogeneity in the Sub-Atlantic Mantle. $\mathrm{Na}$ ture, 295:222.

Masuda, A., 1962. Regularities in variation of relative abundances of lanthanide elements and an attempt to analyze separation-index patterns of some minerals. J. Earth. Sci. Nagoya Univ., 10:173-187.

Morgan, W. J., 1971. Convection plumes in the lower mantle. Nature, 230:42-43.

O'Nions, R. K., Hamilton, P. J., and Evensen, N. M., 1977. Variation in ${ }^{143} \mathrm{Nd} /{ }^{144} \mathrm{Nd}$ and ${ }^{87} \mathrm{Sr} /{ }^{86} \mathrm{Sr}$ ratios in oceanic basalts. Earth Planet. Sci. Lett., 34:13-22.

Pearce, J. A., and Cann, J. R., 1971. Ophiolite origin investigated by discriminant analysis using $\mathrm{Ti}, \mathrm{Zr}$, and Y. Earth Planet. Sci. Lett., 12:339-349.

Rhodes, J. M., Dungan, M. A., Blanchard, D. P., and Long, P. E., 1979. Magma mixing at mid-ocean ridges: evidence from basalts drilled near $22^{\circ} \mathrm{N}$ on the Mid-Atlantic Ridge. Tectonophysics, 55: $35-61$.

Richard, P., Skimizu, N., and Allègre, C. J., $1976 .{ }^{143} \mathrm{Nd} /{ }^{146} \mathrm{Nd}$, a natural tracer: an application to oceanic basalts. Earth Planet. Sci. Lett., 31:269-278.

Ringwood, A. E., 1955. The principles governing trace element behaviour during magmatic crystallization. Part II: The role of complex formation. Geochim. Cosmochim. Acta, 7:242-254.

Schilling, J. G., 1971. Sea-floor evolution: rare earth evidence. Phil. Trans. R. Soc. London. Ser. A., 268:663.

1973. Iceland mantle plumes: Geochemical evidence along Reykjanes Ridge. Nature, 242:565-571.

1975. Azores mantle blob: rare earth evidence. Earth Planet. Sci. Lett., 25:102-115.

Schweitzer, E. L., Papike, J. J., and Bence, E. A., 1979. Statistical analysis of clinopyroxenes from deep-sea basalts. Am. Mineral., 64:501-513.

Shima, M., 1979. The abundances of titanium, zirconium and hafnium in stony meteorites. Geochim. Cosmochim. Acta, 43:353-362.

Stormer, J. C., 1983. Calcium zoning in olivine and its relationships to silica activity and pressure. Geochim. Cosmochim. Acta, 37: 1815-1821.
Sun, S. S., 1973. Lead isotope studies of young volcanic rocks from oceanic islands, mid-ocean ridges and island areas [unpublished Ph.D. thesis]. Columbia University, New York.

Sun, S. S., and Hanson, G. N., 1975. Origin of Ross Island basanitoids and mutations upon the heterogeneity of mantle sources for alkali basalts and nephelinites. Contrib. Mineral. Petrol., 52:77-106.

Sun, S. S., Nesbitt, R. W., and Sharaskin, A. Y., 1979. Geochemical characteristics of mid-ocean ridge basalts. Earth Planet. Sci. Lett., 44(1):119-138.

Sun, S. S., Tatsumoto, M., and Schilling, J. G., 1975. Mantle mixing along the Reykjanes Ridge axis: lead isotopic evidence. Science, 190:143-147.

Tarney, J., Wood, D. A., Saunders, A. D., Cann, J. R., and Varet, J., 1980. Nature of mantle heterogeneity in the North Atlantic: evidence from deep-sea drilling. Phil. Trans. R. Soc. London, A297: 179-202.

Tatsumoto, M., Hedge, C. E., and Engel, A. E. J., 1965. Potassium, rubidium, strontium, thorium, uranium and the ratio of strontium- 87 to strontium- 86 in oceanic tholeiitic basalt. Science, 150: $886-888$.

Treuil, M., 1973. Critères pétrologiques, géochimiques et structuraux de la génèse et de la différentiation des magmas basaltiques: exemple de l'Afar [Thèse Université d'Orléans]. Orléans, France.

Treuil, M., Joron, J. L., Jaffrezic, H., Villemant, B., and Calas, G., 1979. Géochimie des éléments hygromagmaphiles, coefficients de partage minéraux/liquide et propriétés structurales de ces éléments dans les liquides magmatiques. Bull. Mineral., 102:402-409.

Tual, E., Jahn, B. M., and Bougault, H., 1983. R.E.E. Geochemistry of basalts from DSDP Leg 83: Hole 504B. Terra Cognita, 3(213): 145.

White, W. M., and Schilling, J. G., 1978. The nature and origin of geochemical variation in Mid-Atlantic Ridge basalts from the Central North Atlantic. Geochim. Cosmochim. Acta, 42:1501-1516.

White, W. M., Schilling, J. G., and Hart, S. R., 1976. Evidence for the Azores mantle plume from strontium isotope geochemistry of the Central North Atlantic. Nature, 263:659-663.

Wilson, J. T., 1963. Evidence from Islands on spreading of ocean floors. Nature, 197:536.

Wood, D. A., Tarney, J., Varet, J., Saunders, A. A., Bougault, H., Joron, J. L., Treuil, M., and Cann, J., 1979. Geochemistry of basalts drilled in the North Atlantic by IPOD Leg 49: implications for mantle heterogeneity. Earth Planet. Sci. Lett., 42:77-97.

Wood, D. A., Varet, J., Bougault, H., Corre, O., Joron, J. L., Treuil, M., Bizouard, H., Norry, M. J., Hawkesworth, C. J., and Roddick, J. C., 1979. The petrology, geochemistry and mineralogy of North Atlantic basalts: a discussion based on IPOD Leg 49. In Luyendyk, B. P., Cann, J. R., et al., Init. Repts. DSDP, 49: Washington (U.S. Govt. Printing Office), 597-656.

Date of Initial Receipt: 1 August 1983

Date of Acceptance: 22 December 1983 
APPENDIX A

On-board and Onshore Trace Element Data (in ppm), MAPCO Cruise (Bougault and Treuil, 1980)

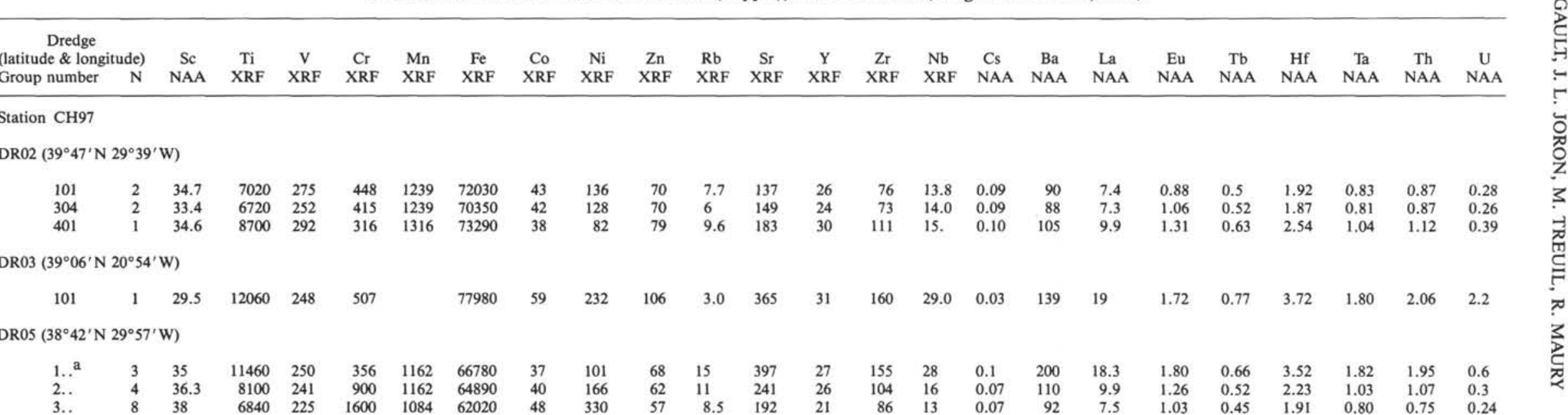

$\operatorname{DR} 06\left(38^{\circ} 31^{\prime} \mathrm{N} 30^{\circ} 18^{\prime} \mathrm{W}\right)$

$$
\begin{array}{lllllllllllllllllllllllllll}
1 . . & 6 & 35 & 11100 & 350 & 25 & 1500 & 85000 & 42 & 24 & 88 & 16.5 & 260 & 32 & 135 & 31 & 0.18 & 220 & 19.5 & 1.90 & 0.85 & 3.45 & 2.10 & 2.30 & 0.67
\end{array}
$$

Station CH98

$\operatorname{DR} 02\left(35^{\circ} 11^{\prime} \mathrm{N} 36^{\circ} 14^{\prime} \mathrm{W}\right)$

$\begin{array}{lllllllllllllllllllllllll}1 . . & 2 & 34.9 & 7400 & 255 & 322 & 1316 & 71630 & 41 & 66 & 67 & 5.5 & 155 & 26 & 75 & 12 & 0.15 & 70 & 7.7 & 1.13 & 0.63 & 2.21 & 0.87 & 0.91 & 0.30 \\ 201 & 1 & 36.6 & 8220 & 305 & 233 & 1626 & 82180 & 45 & 86 & 82 & 0.5 & 110 & 33 & 74 & 8.5 & & 25 & 5.4 & 1.13 & 0.68 & 2.17 & 0.53 & 0.50 & 0.12\end{array}$ $\operatorname{DR} 03\left(33^{\circ} 44^{\prime} \mathrm{N} 37^{\circ} 40^{\prime} \mathrm{W}\right)$

$\begin{array}{lrrrrrrrrrrrrrrrrrrrrrrrr}1 . . & 2 & 30.1 & 4770 & 222 & 568 & 1084 & 58300 & 39 & 140 & 58 & 1.8 & 95 & 23 & 46 & 6 & 0.02 & 16 & 3.1 & 0.74 & 0.44 & 1.41 & 0.76 & 0.39 & 0.21 \\ 201 & 1 & 27.2 & 5220 & 192 & 1102 & 1162 & 65170 & 49 & 337 & 59 & 2 & 102 & 24 & 57 & 5 & & 13 & 3.7 & 0.70 & 0.45 & 1.45 & 0.35 & 0.41 & 0.18 \\ 4 . . & 2 & 29.4 & 5850 & 226 & 880 & 1200 & 69000 & 49 & 300 & 65 & 3 & 92 & 25 & 61 & 6 & & 38 & 3.2 & 0.75 & 0.48 & 1.50 & 0.36 & 0.41 & 0.21\end{array}$

DR04 $\left(33^{\circ} 30^{\prime} \mathrm{N} 39^{\circ} 05^{\prime} \mathrm{W}\right)$

$$
\begin{array}{lllllllllllllllllllllllllll}
1 . . & & 35.2 & 6240 & 235 & 246 & 1300 & 69000 & 40 & 80 & 65 & 1.5 & 99 & 28 & 63 & 1.5 & & 1.45 & 1.00 & 0.6 & 1.62 & 0.09 & 0.07 \\
2 . . & 4 & & & & &
\end{array}
$$

DR05 $\left(33^{\circ} 02^{\prime} \mathrm{N} 39^{\circ} 20^{\prime} \mathrm{W}\right)$

$$
\begin{array}{llllllllllllllllllllllll}
101 & 1 & 37.3 & 8100 & 274 & 427 & 1394 & 79240 & 52 & 171 & 80 & 6.2 & 93 & 35 & 86 & 1 & & & 2.55 & 1.27 & 0.97 & 2.36 & 0.10 & 0.07
\end{array}
$$

DR06 $\left(32^{\circ} 17^{\prime} \mathrm{N} 40^{\circ} 21^{\prime} \mathrm{W}\right)$

$$
\begin{array}{lllllllllllllll}
101 & 1 & 8880 & 294 & 282 & 1471 & 82530 & 46 & 121 & 83 & 1 & 87 & 37 & 91 & 2
\end{array}
$$

DR07 $\left(32^{\circ} 17^{\prime} \mathrm{N} 40^{\circ} 11^{\prime} \mathrm{W}\right)$

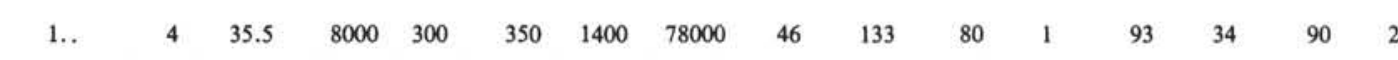


DR08 ( $\left.31^{\circ} 54^{\prime} \mathrm{N} 40^{\circ} 58^{\prime} \mathrm{W}\right)$

\begin{tabular}{|c|c|c|c|c|c|c|c|c|c|c|c|c|c|c|c|c|c|c|c|c|c|c|c|}
\hline $101 / 103$ & 2 & 35.7 & 10260 & 330 & 186 & 1600 & 88000 & 46 & 90 & 96 & 3.1 & 133 & 45 & 134 & 12 & 50 & 9.8 & 1.64 & 0.97 & 3.33 & 0.76 & 1.23 & 0.36 \\
\hline $105 / 501$ & 2 & 37.5 & 10560 & 350 & 150 & 1626 & 88500 & 46 & 66 & 98 & 2.7 & 139 & 46 & 134 & 12.3 & 55 & 11.1 & 1.62 & 1.00 & 3.55 & 0.80 & 1.29 & 0.30 \\
\hline 02 & 1 & 32.5 & 8580 & 262 & 388 & 1394 & 76300 & 39 & 102 & 75 & 2.6 & 111 & 38 & 111 & 9.5 & 31 & 6.6 & 1.30 & 0.89 & 2.86 & 0.49 & 0.79 & \\
\hline & 2 & 36.4 & 8340 & 293 & 321 & 1394 & 80640 & 47 & 123 & 81 & 0.1 & 81 & 38 & 90 & 2 & & 1.9 & 1.24 & 0.79 & 2.48 & 0.11 & 0.1 & \\
\hline
\end{tabular}

DR09 $\left(31^{\circ} 28^{\prime} \mathrm{N} 40^{\circ} 57^{\prime} \mathrm{W}\right)$

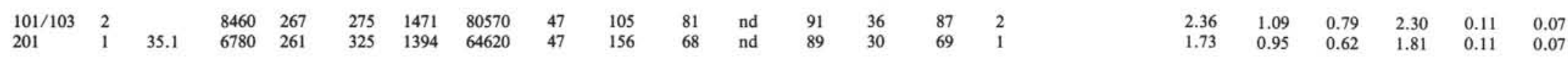

DR10 $\left(31^{\circ} 04^{\prime} \mathrm{N} 41^{\circ} 25^{\prime} \mathrm{W}\right)$

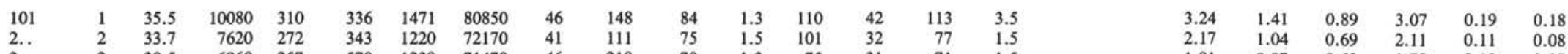

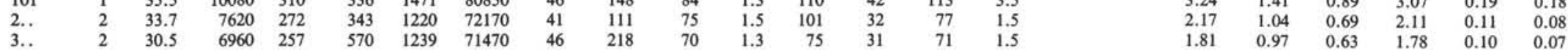

DR11 $\left(30^{\circ} 41^{\prime} \mathrm{N} 41^{\circ} 49^{\prime} \mathrm{W}\right)$

$$
\begin{array}{lllllllllllllllllllllllll}
1 . ., 3 \ldots, 4 \ldots, 7 & 35 & 8660 & 310 & 400 & 400 & 1394 & 46 & 144 & 81 & 1.1 & 92 & 36 & 92 & 1.5 & & & 2.6 & 1.25 & 0.80 & 2.55 & 0.12 & 0.08
\end{array}
$$

DR $12\left(30^{\circ} 10^{\prime} \mathrm{N} 41^{\circ} 55^{\prime} \mathrm{W}\right)$

$103 / 204 \quad 2 \quad 36$

$\begin{array}{lllll}9600 & 310 & 289 & 1471 & 82000\end{array}$

110

$\begin{array}{llllll}89 & 0.7 & 92 & 41 & 103 & 2.5\end{array}$

$\begin{array}{llllll}2.5 & 1.4 & 0.86 & 2.69 & 0.14 & 0.12\end{array}$

DR13 (29 $\left.56^{\prime} \mathrm{N} 42^{\circ} 46^{\prime} \mathrm{W}\right)$

$204 / 301 \quad 2 \quad 38$

$\begin{array}{lllll}8940 & 268 & 330 & 1394 & 77700\end{array}$

$\begin{array}{lllllll}80 & 73 & 2.5 & 122 & 35 & 110 & 3\end{array}$

$\begin{array}{llllll}2.8 & 1.4 & 0.83 & 2.84 & 0.22 & 0.15\end{array}$

DR $14\left(29^{\circ} 17^{\prime} \mathrm{N} 43^{\circ} 05^{\prime} \mathrm{W}\right)$

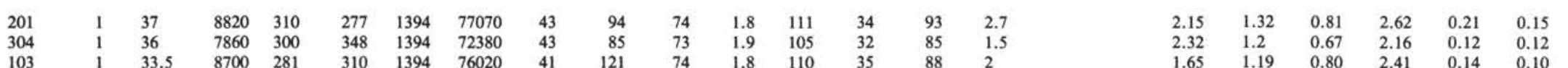

$\operatorname{DR} 15\left(27^{\circ} 46^{\prime} \mathrm{N} 44^{\circ} 05^{\prime} \mathrm{W}\right)$

\begin{tabular}{|c|c|c|c|c|c|c|c|c|c|c|c|c|c|c|c|c|c|c|c|c|c|}
\hline 1... & 2 & 32.7 & 8300 & 263 & 310 & 1300 & 70000 & 38 & 108 & 71 & 2.0 & 128 & 33 & 100 & 3 & 2.6 & 1.3 & 0.72 & 2.42 & 0.17 & 0.13 \\
\hline 201 & 1 & 37.6 & 9360 & & & 1316 & 75250 & 39 & 80 & 75 & 1.2 & 119 & 39 & 112 & 3.5 & 2.8 & 1.33 & 0.85 & 2.87 & 0.19 & 0.14 \\
\hline 202 & 1 & 34.5 & 7320 & & & 1239 & 64750 & & 103 & 65 & 2.7 & 124 & 30 & 92 & 5 & 2.7 & 1.19 & 0.65 & 2.23 & 0.29 & 26 \\
\hline
\end{tabular}

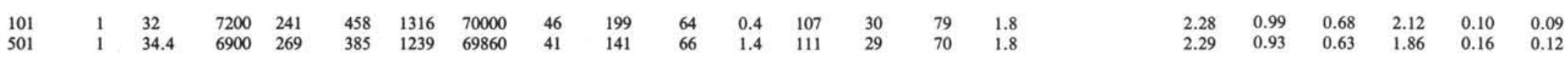

\begin{tabular}{|c|c|c|c|c|c|c|c|c|c|c|c|c|c|c|c|c|c|c|c|c|c|}
\hline 201 & 1 & 39 & 7260 & 196 & 291 & 1162 & 59010 & 35 & 89 & 55 & 3.1 & 167 & 31 & 99 & 2.6 & 2.65 & 1.11 & 0.63 & 2.18 & 0.19 & 0.15 \\
\hline 301 & 1 & 36.7 & 10260 & 300 & 218 & 1394 & 76090 & 39 & 77 & 72 & 1. & 136 & 38 & 125 & 3.5 & 3.9 & 1.55 & 0.86 & 3.00 & 0.24 & 0.18 \\
\hline 401 & 1 & 35.4 & 9000 & 285 & 291 & 1316 & 70350 & 40 & 87 & 66 & 1.7 & 138 & 34 & 110 & 3.0 & 3.0 & 1.42 & 0.75 & 2.67 & 0.21 & 0.14 \\
\hline
\end{tabular}

$\operatorname{DR} 16\left(25^{\circ} 16^{\prime} \mathrm{N} 45^{\circ} 20^{\prime} \mathrm{W}\right)$

DR $17\left(24^{\circ} 28^{\prime} \mathrm{N} 46^{\circ} 15^{\prime} \mathrm{W}\right)$

Note: $\mathrm{N}=$ the number of samples analyzed in each group; NAA = neutron activation analysis; $\mathrm{XRF}=\mathrm{X}$-ray fluorescence; ellipsis points (e.g., $1 \ldots$ ) $=$ ?

For each dredge, the samples were divided into groups; each group is identified by the first digit (2..), and the two other digits are reserved for full sample identification (i.e., 201, 304). If several analyzed samples reveal the group to be homogeneous, only the first digit is used. 
APPENDIX B

Ratios of Hygromagmaphile Element Concentrations Normalized to Chondrites between the Latitudes $40^{\circ} \mathrm{N}$ to $10^{\circ} \mathrm{N}^{\mathrm{a}}$

\begin{tabular}{|c|c|c|c|c|c|c|c|c|c|}
\hline Cruises & Station & $\begin{array}{l}\text { Sample } \\
\text { number }\end{array}$ & $\begin{array}{l}\text { Latitude } \\
\text { (all north) }\end{array}$ & $\begin{array}{l}\text { Longitude } \\
\text { (all west) }\end{array}$ & Depth & $\begin{array}{c}{[\mathrm{La} / \mathrm{Sm}]_{\mathrm{ch}}} \\
\text { (Schilling, } \\
1975)\end{array}$ & {$[\mathrm{La} / \mathrm{Ti}]_{\mathrm{ch}}$} & $\begin{array}{c}{[\mathrm{Ta} / \mathrm{Hf}]_{\mathrm{ch}}} \\
\approx \\
{[\mathrm{Nb} / \mathrm{Zr}]_{\mathrm{ch}}}\end{array}$ & {$[\mathrm{La} / \mathrm{Ta}]_{\mathrm{ch}}$} \\
\hline MAPCO & CH97 DR02 & 101 & $39^{\circ} 46.8^{\prime}$ & $29^{\circ} 38.7^{\prime}$ & 1800 & & 1.56 & 1.78 & 0.89 \\
\hline MAPCO & CH97 DR02 & 304 & $39^{\circ} 46.8^{\prime}$ & $29^{\circ} 38.7^{\prime}$ & 1800 & & 1.61 & 1.79 & 0.90 \\
\hline MAPCO & CH97 DR02 & 401 & $39^{\circ} 46.8^{\prime}$ & $29^{\circ} 38.7^{\prime}$ & 1800 & & 1.69 & 1.69 & 0.95 \\
\hline$T R 89^{\mathrm{b}}$ & $30 \mathrm{D}$ & $2-3$ & $39^{\circ} 37.9^{\prime}$ & $29^{\circ} 44.4^{\prime}$ & $1950-2100$ & 2.5 & & & \\
\hline$T R 89^{b}$ & $30 \mathrm{D}$ & 5 & $39^{\circ} 37.9^{\prime}$ & $29^{\circ} 44.4^{\prime}$ & $1950-2100$ & 2.5 & & & \\
\hline$T R 89^{b}$ & $30 \mathrm{D}$ & $10 \mathrm{~B}$ & $39^{\circ} 37.9^{\prime}$ & $29^{\circ} 44.4^{\prime}$ & $1950-2100$ & 1.8 & & & \\
\hline$T R 89^{b}$ & $31 \mathrm{D}$ & 1 & $39^{\circ} 37.6^{\prime}$ & $29^{\circ} 42.3^{\prime}$ & $1700-1800$ & 3.1 & & & \\
\hline$T R 89^{\mathrm{b}}$ & $31 \mathrm{D}$ & 3 & $39^{\circ} 37.6^{\prime}$ & $29^{\circ} 42.3^{\prime}$ & $1700-1800$ & 2.9 & & & \\
\hline$T R 89^{\mathrm{b}}$ & $31 \mathrm{D}$ & 5 & $39^{\circ} 37.6^{\prime}$ & $29^{\circ} 42.3^{\prime}$ & $1700-1800$ & 1.9 & & & \\
\hline MAPCO & CH97 DR03 & 101 & $39^{\circ} 06^{\prime}$ & $29^{\circ} 54^{\prime}$ & 1400 & & 2.34 & 2.00 & 1.06 \\
\hline MAPCO & CH97 DR05 & $1 . . \mathrm{c}$ & $38.42^{\prime}$ & $29^{\circ} 57^{\prime}$ & 920 & & 2.37 & 2.13 & 1.01 \\
\hline MAPCO & CH97 DR05 & $2 .$. & $38.42^{\prime}$ & $29^{\circ} 57^{\prime}$ & & & 1.81 & 1.91 & 0.96 \\
\hline MAPCO & CH97 DR05 & $3 .$. & $38.42^{\prime}$ & $29^{\circ} 57^{\prime}$ & & & 1.63 & 1.73 & 0.94 \\
\hline GIBRACO & G20 & 01 & $38.36 .0^{\prime}$ & $30.42^{\prime}$ & $1152-1244$ & & 1.06 & 1.26 & 0.91 \\
\hline GIBRACO & G21 & 01 & $38.35 .7^{\prime}$ & $30.40^{\prime}$ & 914 & & & 1.61 & \\
\hline MAPCO & CH97 DR06 & $1 .$. & $38.31^{\prime}$ & $30.18^{\prime}$ & 2200 & & 2.61 & 2.51 & 0.93 \\
\hline TR 89 & $21 \mathrm{D}$ & 1 & $38^{\circ} 26^{\prime}$ & $30^{\circ} 21.4^{\prime}$ & $2700-2850$ & 2.4 & & & \\
\hline$T R 89$ & $21 \mathrm{D}$ & 2 & $38^{\circ} 26^{\prime}$ & $30^{\circ} 21.4^{\prime}$ & $2700-2850$ & 2.3 & & & \\
\hline$T R 89$ & $21 \mathrm{D}$ & 3 & $38^{\circ} 26^{\prime}$ & $30^{\circ} 21.4^{\prime}$ & $2700-2850$ & 2.3 & & & \\
\hline GIBRACO & G22 & 04 & $38^{\circ} 25.4^{\prime}$ & $29^{\circ} 59.6^{\prime}$ & 1350 & & 2.48 & 2.44 & 0.96 \\
\hline TR 89 & $22 \mathrm{D}$ & 1 & $38^{\circ} 25.3^{\prime}$ & $38^{\circ} 27^{\prime}$ & $1750-1850$ & 2.5 & & & \\
\hline$T R 89$ & $22 \mathrm{D}$ & 4 & $38^{\circ} 25.3^{\prime}$ & $38^{\circ} 27^{\prime}$ & $1750-1850$ & 1.9 & & & \\
\hline$T R 89$ & $22 \mathrm{D}$ & 5 & $38^{\circ} 25.3^{\prime}$ & $38^{\circ} 27^{\prime}$ & $1750-1850$ & 1.8 & & & \\
\hline GIBRACO & G17 & 01 & $37^{\circ} 55.2^{\prime}$ & $31.06 .1^{\prime}$ & $2138-2213$ & & 1.69 & 1.92 & 0.86 \\
\hline GIBRACO & G17 & 02 & $37^{\circ} 55.2^{\prime}$ & $31.06 .1^{\prime}$ & $2138-2213$ & & 1.70 & 1.69 & \\
\hline GIBRACO & G17 & 03 & $37^{\circ} 55.2^{\prime}$ & $31.06 .1^{\prime}$ & $2138-2213$ & & & 1.85 & \\
\hline$T R 122$ & 5D & 2 & $37.43 .6^{\prime}$ & $31^{\circ} 28.2^{\prime}$ & $1630-1670$ & 2 & & & \\
\hline$T R 122$ & 5D & 4 & $37.43 .6^{\prime}$ & $31^{\circ} 28.2^{\prime}$ & $1630-1670$ & 2.1 & & & \\
\hline$T R \quad 122$ & SD & 5 & $37.43 .6^{\prime}$ & $31^{\circ} 28.2^{\prime}$ & $1630-1670$ & 2 & & & \\
\hline GIBRACO & G19 & 01 & $37^{\circ} 43.2^{\prime}$ & $30.51 .3^{\prime}$ & $1728-1350$ & & 1.62 & $1.41-1.28$ & 1.01 \\
\hline \multirow[t]{3}{*}{ GIBRACO } & G19 & 04 & $37^{\circ} 43.2^{\prime}$ & $30.51 .3^{\prime}$ & $1728-1350$ & & 1.52 & $1.43-1.22$ & 0.96 \\
\hline & & & $36^{\circ} 56^{\prime}$ & $33^{\circ} 04^{\prime}$ & $2100-2800\}$ & & 1.01 & 1.14 & 1.01 \\
\hline & & & $36^{\circ} 58^{\prime}$ & $33^{\circ} 05^{\prime}$ & $2100-2800\}$ & & 1.48 & 1.50 & 1.01 \\
\hline FAMOUS & & & $36^{\circ} 56^{\prime}$ & $33^{\circ} 09^{\prime}$ & $\sim 3000\}$ & & 0.93 & 1.03 & 1.00 \\
\hline \multirow[t]{3}{*}{ area $1^{d}$} & & & $36^{\circ} 57^{\prime}$ & $33^{\circ} 12^{\prime}$ & $\sim 3000\}$ & & 1.88 & 1.76 & 1.00 \\
\hline & & & $36^{\circ} 50^{\prime}$ & $33^{\circ} 14^{\prime}$ & ) & & 1.22 & 1.24 & 1.00 \\
\hline & & & $36^{\circ} 52^{\prime}$ & $33^{\circ} 17^{\prime}$ & \} & & 1.50 & 1.45 & 1.00 \\
\hline TR 119 & 4D & $1 \mathrm{~B}$ & $36^{\circ} 50.7^{\prime}$ & $33^{\circ} 13.7^{\prime}$ & $2275-2475$ & 1.4 & & & \\
\hline TR 119 & $4 \mathrm{D}$ & $3 \mathrm{~A}$ & $36^{\circ} 50.7^{\prime}$ & $33^{\circ} 13.7^{\prime}$ & $2275-2475$ & 2 & & & \\
\hline TR 119 & $4 D$ & 4 & $36^{\circ} 50.7^{\prime}$ & $33^{\circ} 13.7^{\prime}$ & $2275-2475$ & 1.8 & & & \\
\hline A II 73 & 18 & $6-1$ & $36^{\circ} 46.3^{\prime}$ & $33^{\circ} 18.1^{\prime}$ & 2561 & 1.4 & & & \\
\hline A II 73 & 14 & $4-17$ & $36^{\circ} 45.6^{\prime}$ & $33^{\circ} 17.3^{\prime}$ & 2448 & 1.4 & & & \\
\hline A II 73 & 16 & $5-2$ & $36^{\circ} 43.2^{\prime}$ & $33^{\circ} 17.5^{\prime}$ & 2598 & 1.4 & & & \\
\hline A II 73 & 16 & $5-5$ & $36^{\circ} 43.2^{\prime}$ & $33^{\circ} 17.5^{\prime}$ & 2598 & 1.4 & & & \\
\hline A II 73 & 10 & $2-19$ & $36^{\circ} 43^{\prime}$ & $33^{\circ} 16^{\prime}$ & 2300 & 1.5 & & & \\
\hline A II 73 & 50 & $13-6$ & $36^{\circ} 29^{\prime}$ & $33^{\circ} 38.7^{\prime}$ & 2561 & 1.6 & & & \\
\hline TR 119 & $6 \mathrm{D}$ & $2 \mathrm{~B}$ & $35^{\circ} 50.2^{\prime}$ & $34^{\circ} 10.8^{\prime}$ & $2400-2500$ & 1.4 & & & \\
\hline TR 119 & $6 \mathrm{D}$ & $3 \mathrm{~A}$ & $35^{\circ} 50.2^{\prime}$ & $34^{\circ} 10.8^{\prime}$ & $2400-2500$ & 1.4 & & & \\
\hline TR 119 & $7 \mathrm{D}$ & 1 & $35^{\circ} 20^{\prime}$ & $34^{\circ} 54^{\prime}$ & $2100-2400$ & 3.4 & & & \\
\hline TR 119 & $7 \mathrm{D}$ & 5 & $35^{\circ} 20^{\prime}$ & $34^{\circ} 54^{\prime}$ & $2100-2400$ & 3.6 & & & \\
\hline TR 119 & $7 \mathrm{D}$ & 10 & $35^{\circ} 20^{\prime}$ & $34^{\circ} 54^{\prime}$ & $2100-2400$ & 3.5 & & & \\
\hline MAPCO & CH98 DR02 & $1 .$. & $35.11^{\prime}$ & $36.14^{\prime}$ & $2940-3320$ & & 1.54 & 1.63 & 0.89 \\
\hline MAPCO & CH98 DR02 & 201 & $35.11^{\prime}$ & $36.14^{\prime}$ & $2940-3320$ & & 0.97 & 1.01 & 1.02 \\
\hline$Y-30$ & RD6 & P1 & $35^{\circ} 09^{\prime}$ & $35^{\circ} 43^{\prime}$ & 2020 & 1.1 & & & \\
\hline Y-30 & RD8 & P1 & $35^{\circ} 09^{\prime}$ & $35^{\circ} 44^{\prime}$ & 2135 & 1.7 & & & \\
\hline $\mathrm{Y}-30$ & RD8 & $\mathrm{P} 2$ & $35^{\circ} 09^{\prime}$ & $35^{\circ} 44^{\prime}$ & 2135 & 1.1 & & & \\
\hline Y-30 & RD7 & P3 & $35^{\circ} 08^{\prime}$ & $35^{\circ} 44^{\prime}$ & 2130 & 1.2 & & & \\
\hline Y-30 & RD7 & P10 & $35^{\circ} 08^{\prime}$ & $35^{\circ} 44^{\prime}$ & 2130 & 1.2 & & & \\
\hline Vema & $\mathrm{CH} 77$ DR02 & 1 & $34^{\circ} 56.9^{\prime}$ & $36^{\circ} 24.7^{\prime}$ & $2148-2338$ & & 0.79 & 0.81 & 1.00 \\
\hline Vema & $\mathrm{CH} 77$ DR02 & 2 & $34^{\circ} 56.9^{\prime}$ & $36^{\circ} 24.7^{\prime}$ & $2148-2338$ & & 1.28 & 1.46 & 0.90 \\
\hline Vema & $\mathrm{CH} 77 \mathrm{DR} 02$ & 3 & $34^{\circ} 56.9^{\prime}$ & $36^{\circ} 24.7^{\prime}$ & $2148-2338$ & & & & \\
\hline TR 119 & $8 \mathrm{D}$ & 1 & $34^{\circ} 56.3^{\prime}$ & $36^{\circ} 36.7^{\prime}$ & $1720-1780$ & 2.3 & & & \\
\hline TR 119 & $8 \mathrm{D}$ & 5 & $34^{\circ} 56.3^{\prime}$ & $36^{\circ} 36.7^{\prime}$ & $1720-1780$ & 2.4 & & & \\
\hline TR 123 & 1D & $5 \mathrm{~A}$ & $34^{\circ} 13.9^{\prime}$ & $37^{\circ} 07.6^{\prime}$ & 3100 & 0.95 & & & \\
\hline TR 123 & ID & 6 & $34^{\circ} 13.9^{\prime}$ & $37^{\circ} 07.6^{\prime}$ & 3100 & 0.88 & & & \\
\hline TR 123 & ID & 7 & $34^{\circ} 13.9^{\prime}$ & $37^{\circ} 07.6^{\prime}$ & 3100 & 0.71 & & & \\
\hline$T R \quad 123$ & 1D & $8 \mathrm{~F}$ & $34^{\circ} 13.9^{\prime}$ & $37^{\circ} 07.6^{\prime}$ & 3100 & 0.66 & & & \\
\hline MAPCO & CH98 DR03 & $1 .$. & $33.44^{\prime}$ & $37^{\circ} 40^{\prime}$ & $3340-3580$ & & 0.96 & 1.05 & 0.86 \\
\hline MAPCO & CH98 DR03 & 201 & $33.44^{\prime}$ & $37^{\circ} 40^{\prime}$ & $3340-3580$ & & 1.05 & 1.00 & 1.06 \\
\hline MAPCO & CH98 DR03 & $4 .$. & $33.44^{\prime}$ & $37^{\circ} 40^{\prime}$ & $3340-3580$ & & 0.81 & 0.99 & 0.89 \\
\hline MAPCO & CH98 DR04 & $1 .$. & $33^{\circ} 30.0^{\prime}$ & $39^{\circ} 05^{\prime}$ & $2240-2545$ & & 0.34 & 0.23 & 1.61 \\
\hline MAPCO & CH98 DR04 & $2 .$. & $33^{\circ} 30.0^{\prime}$ & $39^{\circ} 05^{\prime}$ & $2240-2545$ & & & & \\
\hline$T R 123$ & 4D & 5 & $33^{\circ} 22.2^{\prime}$ & $39^{\circ} 04.8^{\prime}$ & 1950 & 0.35 & & & \\
\hline
\end{tabular}


Appendix B. (Continued).

\begin{tabular}{|c|c|c|c|c|c|c|c|c|c|}
\hline Cruises & Station & $\begin{array}{l}\text { Sample } \\
\text { number }\end{array}$ & $\begin{array}{l}\text { Latitude } \\
\text { (all north) }\end{array}$ & $\begin{array}{l}\text { Longitude } \\
\text { (all west) }\end{array}$ & Depth & $\begin{array}{c}{[\mathrm{La} / \mathrm{Sm}]_{\mathrm{ch}}} \\
\text { (Schilling, } \\
1975)\end{array}$ & {$[\mathrm{La} / \mathrm{Ti}]_{\mathrm{ch}}$} & $\begin{array}{c}{[\mathrm{Ta} / \mathrm{Hf}]_{\mathrm{ch}}} \\
\approx \\
{[\mathrm{Nb} / \mathrm{Zr}]_{\mathrm{ch}}}\end{array}$ & {$[\mathrm{La} / \mathrm{Ta}]_{\mathrm{ch}}$} \\
\hline TR 123 & 4D & 7 & $33^{\circ} 22.2^{\prime}$ & $39^{\circ} 04.8^{\prime}$ & 1950 & 0.24 & & & \\
\hline$T R 123$ & $4 \mathrm{D}$ & 9 & $33^{\circ} 22.2^{\prime}$ & $39^{\circ} 04.8^{\prime}$ & 1950 & 0.32 & & & \\
\hline MAPCO & CH98 DR05 & 101 & $33^{\circ} 02^{\prime}$ & $39^{\circ} 20^{\prime}$ & $2480-2800$ & & 0.47 & 0.17 & 2.55 \\
\hline$T R 123$ & SD & 1 & $32^{\circ} 37.4^{\prime}$ & $39^{\circ} 52.1^{\prime}$ & 2700 & 0.45 & & & \\
\hline$T R 123$ & SD & 2 & $32^{\circ} 37.4^{\prime}$ & $39^{\circ} 52.1^{\prime}$ & 2700 & 0.55 & & & \\
\hline$T R 123$ & SD & 3 & $32^{\circ} 37.4^{\prime}$ & $39^{\circ} 52.1^{\prime}$ & 2700 & 0.53 & & & \\
\hline MAPCO & CH98 DR06 & 101 & $32^{\circ} 17^{\prime}$ & $40^{\circ} 21^{\prime}$ & $2280-2320$ & & & $0.21^{\mathrm{e}}$ & \\
\hline MAPCO & CH98 DR07 & $1 .$. & $33^{\circ} 17^{\prime}$ & $40^{\circ} 11^{\prime}$ & $3000-3380$ & & 0.43 & 0.22 & 1.92 \\
\hline MAPCO & CH98 DR08 & 101 & $31^{\circ} 54^{\prime}$ & $40^{\circ} 58^{\prime}$ & $3100-3300$ & & 1.42 & 0.94 & 1.29 \\
\hline MAPCO & CH98 DR08 & 105 & $31^{\circ} 54^{\prime}$ & $40^{\circ} 58^{\prime}$ & $3100-3300$ & & 1.56 & 0.93 & 1.39 \\
\hline MAPCO & CH98 DR08 & 102 & $31^{\circ} 54^{\prime}$ & $40^{\circ} 58^{\prime}$ & $3100-3300$ & & 1.14 & 0.71 & 1.35 \\
\hline MAPCO & CH98 DR08 & $2 .$. & $31^{\circ} 54^{\prime}$ & $40^{\circ} 58^{\prime}$ & $3100-3300$ & & 0.34 & 0.18 & 1.73 \\
\hline A 150 & RD & 8 & $31^{\circ} 49^{\prime}$ & $42^{\circ} 25^{\prime}$ & 3700 & 0.59 & & & \\
\hline MAPCO & CH98 DR09 & 101 & $31^{\circ} 28^{\prime}$ & $48^{\circ} 57^{\prime}$ & 3000 & & 0.41 & 0.2 & 2.15 \\
\hline MAPCO & CH98 DR09 & 201 & $31^{\circ} 28^{\prime}$ & $48^{\circ} 57^{\prime}$ & 3000 & & 0.38 & 0.25 & 1.57 \\
\hline MAPCO & CH98 DR10 & 101 & $31^{\circ} 04^{\prime}$ & $41^{\circ} 25^{\prime}$ & 3100 & & 0.48 & 0.26 & 1.71 \\
\hline MAPCO & CH98 DR10 & $2 .$. & $31^{\circ} 04^{\prime}$ & $41^{\circ} 25^{\prime}$ & 3100 & & 0.42 & 0.22 & 1.97 \\
\hline MAPCO & CH98 DR10 & 3. & $31^{\circ} 04^{\prime}$ & $41^{\circ} 25^{\prime}$ & 3100 & & 0.39 & 0.23 & 1.81 \\
\hline MAPCO & CH98 DR11 & $1 \ldots$ & $30^{\circ} 41^{\prime}$ & $41^{\circ} 49^{\prime}$ & $3500-3640$ & & 0.45 & 0.19 & 2.17 \\
\hline MAPCO & CH98 DR12 & 103 & $30^{\circ} 10^{\prime}$ & $41^{\circ} 55^{\prime}$ & $4130-4230$ & & 0.39 & 0.21 & 1.79 \\
\hline A 150 & RD & 20 & $30^{\circ} 04^{\prime}$ & $42^{\circ} 16^{\prime}$ & 4144 & 0.45 & & & \\
\hline A 150 & RD & 7 & $30^{\circ} 01^{\prime}$ & $42^{\circ} 04^{\prime}$ & 4280 & 0.58 & & & \\
\hline MAPCO & CH98 DR13 & 204 & $29^{\circ} 56^{\prime}$ & $42^{\circ} 46^{\prime}$ & $3300-3780$ & & 0.46 & 0.32 & 1.27 \\
\hline Vema & CH77 DR03 & 104 & $29^{\circ} 37.3^{\prime}$ & $42^{\circ} 49.7^{\prime}$ & $3210-3300$ & & 0.51 & 0.35 & 1.36 \\
\hline Vema & CH77 DR03 & 205 & $29^{\circ} 37.3^{\prime}$ & $42^{\circ} 49.7^{\prime}$ & $3210-3300$ & & 0.57 & 0.86 & 0.76 \\
\hline MAPCO & CH98 DR14 & 201 & $29^{\circ} 16^{\prime}$ & $43^{\circ} 05^{\prime}$ & $2300-2500$ & & 0.36 & 0.33 & 1.02 \\
\hline MAPCO & CH98 DR14 & 304 & $29^{\circ} 16^{\prime}$ & $43^{\circ} 05^{\prime}$ & $2300-2500$ & & 0.44 & 0.23 & 1.93 \\
\hline MAPCO & CH98 DR14 & 103 & $29^{\circ} 16^{\prime}$ & $43^{\circ} 05^{\prime}$ & $2300-2500$ & & 0.28 & 0.24 & 1.18 \\
\hline MAPCO & CH98 DR15 & 101 & $27^{\circ} 46^{\prime}$ & $44^{\circ} 05^{\prime}$ & $3340-3840$ & & 0.47 & 0.19 & 2.28 \\
\hline MAPCO & CH98 DR15 & 501 & $27^{\circ} 46^{\prime}$ & $44^{\circ} 05^{\prime}$ & $3340-3840$ & & 0.49 & 0.36 & 1.43 \\
\hline MAPCO & CH98 DR16 & $1 .$. & $25^{\circ} 16^{\prime}$ & $45^{\circ} 20^{\prime}$ & $2760-3900$ & & 0.46 & 0.29 & 1.53 \\
\hline MAPCO & CH98 DR16 & 201 & $25^{\circ} 16^{\prime}$ & $45^{\circ} 20^{\prime}$ & $2760-3900$ & & 0.44 & 0.27 & 1.47 \\
\hline MAPCO & CH98 DR16 & 202 & $25^{\circ} 16^{\prime}$ & $45^{\circ} 20^{\prime}$ & $2760-3900$ & & 0.55 & 0.54 & 0.93 \\
\hline MAPCO & CH98 DR17 & 201 & $24^{\circ} 28^{\prime}$ & $46^{\circ} 15^{\prime}$ & $4200-4500$ & & 0.54 & 0.36 & 1.39 \\
\hline MAPCO & CH98 DR17 & 301 & $24^{\circ} 28^{\prime}$ & $46^{\circ} 15^{\prime}$ & $4200-4500$ & & 0.56 & 0.33 & 1.63 \\
\hline MAPCO & CH98 DR17 & 401 & $24^{\circ} 28^{\prime}$ & $46^{\circ} 15^{\prime}$ & $4200-4500$ & & 0.49 & 0.32 & 1.43 \\
\hline Vema & CH77 DR04 & 170 & $23^{\circ} 42^{\prime}$ & $45^{\circ} 28^{\prime}$ & 4200 & & 0.47 & 0.25 & 1.83 \\
\hline Vema & CH77 DR04 & 105 & $23^{\circ} 42^{\prime}$ & $45^{\circ} 28^{\prime}$ & 4200 & & 0.55 & 0.21 & 2.33 \\
\hline Vema & $\mathrm{CH} 77$ DR05 & 401 & $23^{\circ} 25^{\prime}$ & $44^{\circ} 59^{\prime}$ & 4416 & & 0.48 & 0.20 & 2.17 \\
\hline Vema & CH77 DR05 & 107 & $23^{\circ} 25^{\prime}$ & $44^{\circ} 59^{\prime}$ & 4416 & & 0.58 & 0.26 & 1.87 \\
\hline Vema & CH77 DR06 & 201 & $14^{\circ} 07^{\prime}$ & $45^{\circ} 00^{\prime}$ & 2954 & & 1.5 & 1.79 & 0.88 \\
\hline Vema & $\mathrm{CH} 77$ DR06 & 157 & $14^{\circ} 07^{\prime}$ & $45^{\circ} 00^{\prime}$ & 2954 & & 1.85 & 2.02 & 0.89 \\
\hline Vema & CH77 DR08 & 26 & $10^{\circ} 37^{\prime}$ & $40^{\circ} 50^{\prime}$ & 4339 & & 0.5 & 0.22 & 2.09 \\
\hline Vema & $\mathrm{CH} 77$ DR08 & 46 & $10^{\circ} 37^{\prime}$ & $40^{\circ} 50^{\prime}$ & 4339 & & 0.58 & 0.22 & 2.13 \\
\hline
\end{tabular}

a Data from Schilling (1975) and Bougalt (1980).

b $T R$ represents the ship Trident.

c Ellipsis points (e.g., 1..) indicate a homogeneous group. (See note a, Appendix A.)

d No station or sample numbers given for FAMOUS area 1. Measurements indicate the ranges of variation within the given latitude and longitude.

e $(\mathrm{Nb} / \mathrm{Zr})_{\mathrm{ch}}$. 


\begin{tabular}{|c|c|c|c|c|c|c|c|c|c|c|c|c|c|c|c|c|c|c|c|c|c|c|c|c|c|c|c|}
\hline $\begin{array}{l}\text { Chemical } \\
\text { group }\end{array}$ & $\mathrm{N}$ & $\begin{array}{c}\mathrm{Sc} \\
\mathrm{NAA}\end{array}$ & $\underset{X R F}{\mathrm{Ti}}$ & $\underset{X R F}{v}$ & $\underset{\mathrm{XRF}}{\mathrm{Cr}}$ & $\underset{\mathrm{XRF}}{\mathrm{Mn}}$ & $\begin{array}{c}\mathrm{Fe} \\
\mathrm{XRF}\end{array}$ & $\begin{array}{c}\text { Co } \\
\text { XRF }\end{array}$ & $\begin{array}{c}\text { Co } \\
\text { NAA }\end{array}$ & $\underset{\mathrm{XRF}}{\mathrm{Ni}}$ & $\begin{array}{c}\mathrm{Ni} \\
\mathrm{NAA}\end{array}$ & $\underset{\mathrm{XRF}}{\mathrm{Zn}}$ & $\begin{array}{c}\mathrm{Rb} \\
\mathrm{XRF}\end{array}$ & $\begin{array}{c}\mathrm{Rb} \\
\mathrm{NAA}\end{array}$ & $\underset{\mathrm{XRF}}{\mathrm{Sr}}$ & $\underset{\mathrm{XRF}}{\mathrm{Y}}$ & $\underset{\mathrm{XRF}}{\mathrm{Zr}}$ & $\begin{array}{c}\mathrm{Nb} \\
\mathrm{XRF}\end{array}$ & $\begin{array}{c}\mathrm{Cs} \\
\mathrm{NAA}\end{array}$ & $\begin{array}{c}\mathrm{Ba} \\
\mathrm{NAA}\end{array}$ & $\begin{array}{c}\mathrm{La} \\
\mathrm{NAA}\end{array}$ & $\begin{array}{c}\text { Eu } \\
\text { NAA }\end{array}$ & $\begin{array}{c}\text { Tb } \\
\text { NAA }\end{array}$ & $\begin{array}{c}\mathrm{Hf} \\
\text { NAA }\end{array}$ & $\begin{array}{c}\mathrm{Ta} \\
\text { NAA }\end{array}$ & $\begin{array}{c}\text { Th } \\
\text { NAA }\end{array}$ & $\underset{\text { NAA }}{U}$ \\
\hline \multicolumn{28}{|l|}{ Hole 556} \\
\hline I & 2 & 38.6 & 6300 & 277 & 264 & 1239 & 62,475 & 41 & 46 & 116 & 116 & 67 & 3.2 & 2.2 & 104 & 28.2 & 62.5 & 0.8 & 0.10 & 21 & 1.8 & 0.94 & 0.58 & 1.77 & 0.1 & 0.09 & 06 \\
\hline II & 16 & 37.0 & 8640 & 280 & 246 & 1335 & 76,085 & 39.9 & 42.7 & 75.4 & 80.2 & 74.9 & 4.7 & 5.3 & 100 & 38.9 & 94 & 2.0 & 0.23 & 20 & 2.6 & 1.21 & 0.79 & 2.53 & 0.14 & 0.13 & 0.04 \\
\hline \multirow{3}{*}{ III } & & 0.8 & 316 & 10 & 12 & 96 & 2180 & 1.9 & 1.8 & 6.8 & 7.7 & 4.3 & 2.3 & 1.9 & 2.5 & 1.6 & 6 & 0.7 & 0.19 & 5 & 0.2 & 0.06 & 0.04 & 0.16 & 0.01 & 0.02 & \multirow{3}{*}{$\begin{array}{l}0.01 \\
0.08 \\
0.03\end{array}$} \\
\hline & 11 & 37.8 & 5693 & 249 & 262 & 1238 & 64,500 & 38.9 & 43.8 & 93 & 93.7 & 58.6 & 4.6 & 3.8 & 101 & 26.2 & 57 & 1.3 & 0.18 & 15 & 1.5 & 0.89 & 0.53 & 1.50 & 0.08 & 0.08 & \\
\hline & & 1.7 & 547 & 14 & 105 & 77 & 3970 & 3.7 & 4.5 & 13 & 12 & 4 & 0.7 & \multirow{3}{*}{4.7} & 2.3 & 2.3 & 3 & 0.7 & 0.07 & \multirow{3}{*}{30} & 0.2 & 0.07 & 0.04 & 0.14 & \multirow{3}{*}{0.13} & 0.02 & \\
\hline \multirow{2}{*}{$\begin{array}{l}\text { Iv } \\
\text { v }\end{array}$} & 2 & 41.0 & 8160 & 326 & 48 & 1277 & 67,095 & 48 & 52 & 74 & 72 & 87 & 4.7 & & 113 & 38.4 & 80 & \multirow[t]{2}{*}{2.2} & 0.15 & & 2.4 & 1.25 & 0.76 & 2.35 & & 0.11 & \multirow{2}{*}{0.03} \\
\hline & 2 & 32.5 & 1800 & 163 & 70 & 1000 & 45,600 & 31 & 35 & 95 & 109 & 28 & 0.3 & & 90 & 10 & 11 & & 0.02 & & 0.3 & 0.41 & 0.12 & 0.19 & & 0.02 & \\
\hline \multicolumn{28}{|l|}{ Hole 557} \\
\hline \multirow{2}{*}{$\underset{l}{\mathrm{H} I \mathrm{CC}}$} & 1 & 33.7 & 19,560 & 313 & 24 & 1394 & 107,380 & 42 & 43.3 & 25 & 28 & 128 & 11.3 & 10.7 & 344 & 49 & 219 & 43 & 0.05 & 161 & 27.2 & 2.64 & 1.16 & 5.2 & 2.83 & 2.69 & 0.9 \\
\hline & 3 & $\begin{array}{r}38.1 \\
0.2\end{array}$ & $\begin{array}{r}20,960 \\
124\end{array}$ & $\begin{array}{r}432 \\
23\end{array}$ & $\begin{array}{r}36 \\
5\end{array}$ & $\begin{array}{r}1600 \\
160\end{array}$ & $\begin{array}{r}114,260 \\
2760\end{array}$ & $\begin{array}{r}49 \\
1\end{array}$ & 50 & $\begin{array}{r}43 \\
8\end{array}$ & 40 & 100 & 9.7 & 10.0 & $\begin{array}{r}309 \\
8\end{array}$ & 48 & 220 & $\begin{array}{r}30.0 \\
0.2\end{array}$ & 0.07 & 122 & 20.3 & $\begin{array}{l}2.67 \\
0.02\end{array}$ & $\begin{array}{l}1.22 \\
0.04\end{array}$ & $\begin{array}{l}5.62 \\
0.06\end{array}$ & $\begin{array}{l}2.15 \\
0.01\end{array}$ & $\begin{array}{l}1.96 \\
0.10\end{array}$ & $\begin{array}{l}0.72 \\
0.04\end{array}$ \\
\hline Hole 558 & $\bullet$ & & & & & & & & & & & & & & & & & & & & & & & & & & \\
\hline 1 & 1 & 32.2 & 7260 & 207 & 490 & 1239 & 75,740 & 47 & 50 & 259 & 287 & 73 & 3.6 & 1.9 & 128 & 26.6 & 83 & 8.6 & 0.06 & 40 & 5.7 & 1.03 & 0.56 & 1.95 & 0.57 & 0.53 & 0.15 \\
\hline it & 3 & 37.6 & 6660 & 255 & 369 & 1188 & 69,930 & 44 & 46.8 & 141 & 144 & 73 & 3.9 & 3.4 & 92 & 29.3 & 66 & $\begin{array}{l}3.0 \\
3.2\end{array}$ & 0.19 & 10 & 2.5 & 0.99 & 0.57 & 1.81 & 0.16 & 0.16 & 0.07 \\
\hline & & 0.6 & 60 & 2 & 9 & 44 & 3620 & 1 & 1.6 & 10 & 13 & 1 & 0.7 & 0.7 & 4 & 0.5 & $\begin{array}{r}{ }_{3} \\
3\end{array}$ & 0.3 & 0.10 & & 0.2 & 0.04 & 0.02 & 0.05 & 0.01 & 0.01 & 0.01 \\
\hline III A & 3 & 34.5 & 8362 & 277 & 342 & 1171 & 71,030 & 42.4 & 44.7 & 156 & 159 & 76 & 6.9 & 6.7 & 172 & 28.7 & 92 & 15.6 & 0.27 & 52 & 9.7 & 1.19 & 0.62 & 2.31 & 0.98 & 0.95 & 0.33 \\
\hline & & 0.5 & 71 & 4 & 6 & 96 & 1240 & 2.0 & 1.7 & 8 & 13 & 1 & 1.9 & 2.3 & 3 & 0.7 & 4 & 0.9 & 0.16 & 20 & 0.2 & 0.03 & 0.01 & 0.08 & 0.01 & 0.03 & 0.04 \\
\hline III B & 5 & 34.5 & 7788 & 272 & 368 & 1084 & 68,796 & 42.8 & 43.9 & 156 & 155 & 73 & 5.2 & 5.2 & 180 & 26.0 & 81 & 13.6 & 0.19 & 36 & 8.9 & 1.11 & 0.56 & 2.09 & 0.89 & 0.88 & 0.23 \\
\hline & & 0.6 & 149 & 13 & 11 & 55 & 1858 & 2.3 & 1.5 & 7 & 10 & 3 & 1.1 & 1.8 & 5 & 0.9 & 2 & 0.6 & 0.10 & 13 & 0.2 & 0.03 & 0.01 & 0.04 & 0.02 & 0.04 & 0.05 \\
\hline IV & 5 & 35.3 & 7236 & 267 & 365 & 1208 & 70,546 & 43.4 & 45.8 & 177 & 182 & 72 & 5.9 & 5.6 & 144 & 27.3 & 80 & 10.5 & 0.23 & 37 & 6.9 & 1.05 & 0.58 & 2.07 & 0.67 & 0.72 & 0.20 \\
\hline & & 0.5 & 202 & 13 & 14 & 42 & 1219 & 2.4 & 1.3 & 16 & 12 & 2 & 0.6 & 0.6 & 4 & 1.7 & 9 & 1.2 & 0.09 & 20 & 0.1 & 0.07 & 0.03 & 0.06 & 0.06 & 0.13 & 0.03 \\
\hline $\mathrm{v}$ & 6 & 34.3 & 5700 & 224 & 447 & 1239 & 70,280 & 48.3 & 50.5 & 217 & 222 & 65 & 4.6 & 3.9 & 115 & 22.5 & 61 & 7.2 & 0.27 & 18 & 5.0 & 0.84 & 0.45 & 1.48 & 0.48 & 0.45 & 0.13 \\
\hline & & 1.0 & 147 & 14 & 14 & 69 & 1250 & 2.1 & 1.8 & 15 & 17 & 8 & 0.2 & 0.5 & 3 & 0.5 & 3 & 0.7 & 0.05 & 5 & 0.3 & 0.04 & 0.01 & 0.08 & 0.02 & 0.03 & 0.03 \\
\hline $558-41-2,143-1$ & & 35.9 & 5460 & 194 & 444 & 1239 & 74,060 & 50 & 52.8 & 219 & 235 & 61 & 3.2 & 2.3 & 107 & 22.7 & 51 & 2.0 & 0.22 & & 1.7 & 0.77 & 0.46 & 1.30 & 0.14 & 0.12 & 0.05 \\
\hline Hole 559 & 0 & & & & & & & & & & & & & & & & & & & & & & & & & & \\
\hline 1 & 26 & 38.6 & 9093 & 317 & 272 & 1269 & 80,435 & 43 & 42.7 & 115 & 112.9 & 90 & 8.4 & 7.4 & 174 & 35.2 & 104 & 16.2 & 0.38 & 44 & 9.4 & 1.29 & 0.72 & 2.69 & 1.02 & 1.02 & 0.36 \\
\hline & & 2.8 & 400 & 43 & 16 & 183 & 5000 & 5 & 4.4 & 19 & 18.5 & 19 & 2.5 & 2.5 & 13 & 3.3 & 5 & 1.0 & 0.20 & 17 & 1.0 & 0.08 & 0.05 & 0.17 & 0.05 & 0.08 & 0.15 \\
\hline Hole 560 & 0 & & & & & & & & & & & & & & & & & & & & & & & & & & \\
\hline $540-2-1,93-96$ & & 5.9 & 7140 & 268 & 387 & 852 & 45,080 & 124 & 144 & 296 & 288 & 82 & 1.2 & 1.1 & 121 & 29.2 & 73 & 6.2 & 0.02 & 22 & 3.7 & 1.02 & 0.6 & 1.91 & 0.38 & 0.38 & 0.08 \\
\hline Hole 561 & 0 & & & & & & & & & & & & & & & & & & & & & & & & & & \\
\hline 1 & 2 & & & & & & 69,440 & 46.5 & 48 & 199 & 195 & 69 & 4.2 & 4.8 & & 30.4 & 98 & 22.1 & 0.05 & 50 & 12.4 & 1.26 & 0.65 & 2.49 & 1.39 & 1.56 & 0.38 \\
\hline II & 6 & 40.6 & 7980 & 352 & 228 & 1380 & 77,812 & 50.3 & 52.6 & 152 & 146 & 88 & 5.9 & 5.7 & 9.2 & 38.4 & 75 & 2.9 & 0.20 & 10 & 2.5 & 1.20 & 0.77 & 2.18 & 0.18 & 0.20 & 0.08 \\
\hline & & 0.6 & 161 & 6 & 7 & 58 & 1651 & 4.5 & 5.8 & 37 & 39 & ${ }_{3}$ & 4.3 & 5.5 & 4 & 0.6 & 3 & 0.9 & 0.20 & 3 & 0.1 & 0.05 & 0.02 & 0.06 & 0.01 & 0.02 & 0.03 \\
\hline Hole 562 & $\nabla$ & & & & & & & & & & & & & & & & & & & & & & & & & & \\
\hline I & 19 & 40.0 & 9258 & 326 & 229 & 1394 & 81.432 & 42.7 & 44.6 & & 93.8 & 80 & 40 & 3.9 & 101 & 412 & 94 & & 0.20 & 10 & 29 & 30 & 0.84 & 260 & 0.19 & 0.17 & 0.07 \\
\hline & & $\begin{array}{l}4.00 \\
1.3\end{array}$ & $\begin{array}{r}9238 \\
188\end{array}$ & $\begin{array}{r}326 \\
12\end{array}$ & $\begin{array}{r}229 \\
7\end{array}$ & $\begin{array}{r}1394 \\
63\end{array}$ & $\begin{array}{r}8,4,422 \\
2172\end{array}$ & $\begin{array}{r}4.1 \\
1.5\end{array}$ & $\begin{array}{l}44.0 \\
1.5\end{array}$ & $\begin{array}{r}93.3 \\
6.7\end{array}$ & $\begin{array}{r}93.8 \\
6.5\end{array}$ & $\begin{array}{r}80 \\
4\end{array}$ & $\begin{array}{l}4.0 \\
2.9\end{array}$ & $\begin{array}{l}3.9 \\
2.9\end{array}$ & 6 & $\begin{array}{r}4.2 \\
1.2\end{array}$ & $\begin{array}{r}94 \\
3\end{array}$ & $\begin{array}{l}2.9 \\
0.6\end{array}$ & $\begin{array}{l}0.20 \\
0.23\end{array}$ & 4 & 0.2 & 0.09 & 0.02 & 0.06 & 0.02 & 0.03 & 0.05 \\
\hline II & 5 & 34.9 & 6816 & 291 & 239 & 1177 & 69,510 & 40.6 & 42.7 & 96.6 & 96.2 & 68 & 3.8 & 3.6 & 97 & 30.8 & 68 & 2.5 & 0.18 & 11 & 2.2 & 0.99 & 0.65 & 1.85 & 0.16 & 0.13 & 0.05 \\
\hline & & 1.1 & $\begin{array}{l}156 \\
\end{array}$ & 10 & 16 & 100 & 1383 & 1.5 & 1.4 & 7.4 & 6.3 & 4 & 1.7 & 1.5 & 9 & 0.8 & ${ }_{2}^{\infty}$ & 0.7 & 0.13 & 5 & 0.1 & 0.04 & 0.06 & 0.06 & 0.01 & 0.01 & 0.01 \\
\hline II' & 2 & 37.5 & 7470 & 337 & 263 & 1355 & 78.715 & 44 & 45 & 101 & 93 & 79 & 10.1 & 9.6 & 101 & 33.0 & 75 & 3.3 & 0.46 & 15 & 2.6 & 1.09 & 0.68 & 2.05 & 0.18 & 0.15 & 0.08 \\
\hline Hole 563 & $\Delta$ & & & & & & & & & & & & & & & & & & & & & & & & & & \\
\hline 1 & 4 & 41.1 & 5940 & 329 & 316 & 1277 & 74,970 & 41.7 & 44.0 & 99.5 & 100.5 & 68 & 8.3 & 8.5 & 85 & 27.5 & 55 & 1.6 & 0.28 & & 1.8 & 0.90 & 0.56 & 1.54 & 0.12 & 0.13 & 0.09 \\
\hline & & 1.0 & 235 & 14 & 12 & 77 & 2809 & 0.5 & 2.0 & 7.9 & 9.0 & 3 & 2.4 & 1.7 & 2 & 0.6 & 2 & 0.6 & 0.08 & & 0.2 & 0.06 & 0.01 & 0.07 & 0.01 & 0.02 & - \\
\hline II & 6 & 39.7 & 5790 & 317 & 301 & 1227 & 67,246 & 43.3 & 47.1 & 119.2 & 116.7 & 66 & 3.1 & 2.6 & 84 & 27.3 & 53 & 1.7 & 0.11 & & 1.7 & 0.88 & 0.54 & 1.51 & 0.12 & 0.11 & 0.08 \\
\hline & & 0.6 & 73 & 3 & 7 & 30 & 1560 & 2.7 & 3.8 & 14.2 & 13.7 & 3 & 1.4 & 1.8 & 1 & 0.4 & 3 & 0.6 & 0.05 & & 0.2 & 0.03 & 0.02 & 0.04 & 0.01 & 0.01 & - \\
\hline Hole 564 & $\Delta$ & & & & & & & & & & & & & & & & & & & & & & & & & & \\
\hline 1 & 26 & 40.9 & 8610 & 394 & 247 & 1358 & 82,790 & 46.8 & 47.0 & 116.3 & 114.9 & 83 & 5.4 & 4.9 & 105 & 39.3 & 92 & 4.6 & 0.28 & 17 & 3.7 & 1.25 & 0.79 & 2.52 & 0.30 & 0.29 & 0.09 \\
\hline & & 0.8 & 149 & 26 & 16 & 63 & 3104 & 3.0 & 3.8 & 14.1 & 13.8 & 4 & 2.0 & 2.0 & 4 & 1.3 & 4 & 1.0 & 0.15 & 7 & 0.3 & 0.06 & 0.03 & 0.11 & 0.04 & 0.06 & 0.04 \\
\hline
\end{tabular}

